\title{
Einfluss von Gibberellin auf den \\ Gravitropismus der Wurzel durch Regulation der PIN-Stabilität
}

\section{Dissertation}

zur Erlangung des

mathematisch-naturwissenschaftlichen Doktorgrades

„Doctor rerum naturalium“

vorgelegt von

Christian Löfke

aus

Heidelberg

angefertigt am

Albrecht-von-Haller-Institut für Pflanzenwissenschaften

Abteilung Zellbiologie der Pflanze

an der biologischen Fakultät

der Georg-August-Universität Göttingen

Göttingen 2011 
Hiermit versichere ich, dass ich diese Dissertationsarbeit mit dem Titel „Einfluss von Gibberellin auf den Gravitropismus der Wurzel durch Regulation der PIN-Stabilität“" selbständig verfasst und keine anderen als die angegebenen Quellen und Hilfsmittel benutzt habe. Ich erkläre hiermit auch, dass ich mich an keiner anderen Universität um einen Doktorgrad beworben habe.

Christian Löfke

Göttingen, den 29. März 2011

Referent: $\quad$ Prof. Dr. Jiri Friml

Korreferent: $\quad$ Prof. Dr. Ingo Heilmann

Anleiter: $\quad$ PD Dr. Thomas Teichmann

Tag der mündlichen Prüfung: 29. April 2011 
Inhaltsverzeichnis

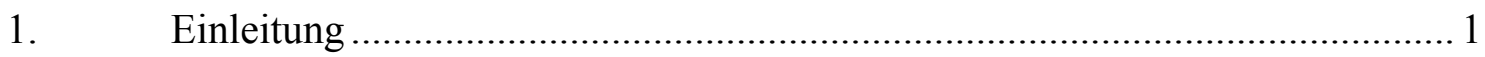

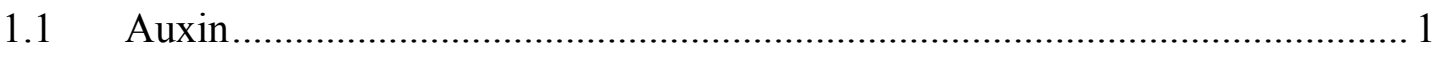

1.1.1 Auxintransporter und ihre Verteilung .................................................... 2

1.1.2 Intrazelluläre Migrationswege (Endomembranfluss) .................................5

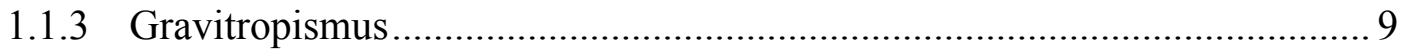

1.1.4 Auxinwechselwirkung mit der GA-Biosynthese und GA-Perzeption ........ 10

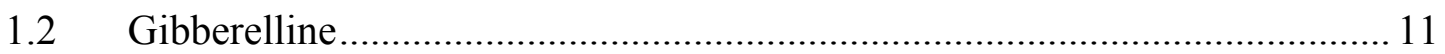

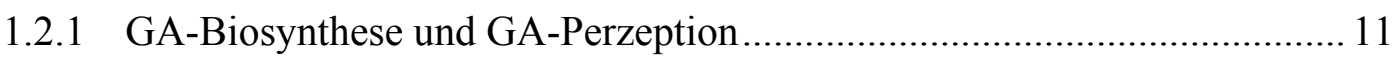

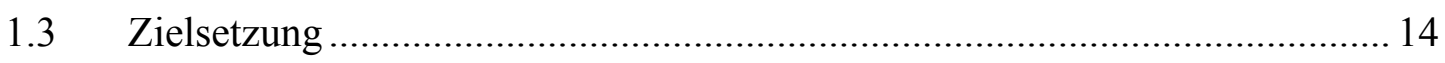

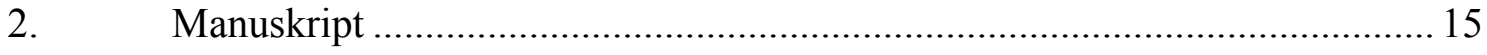

3. Zusammenfassung des Manuskripts …......................................................50

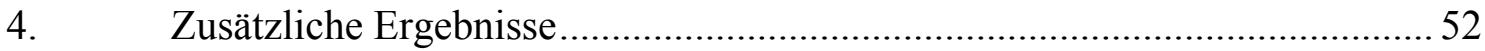

4.1 Redundante Funktion der DELLA-Gene .................................................... 52

4.2 DELLA-abhängige Wechselwirkung zwischen GA-Signaltransduktion und Auxintransport.

4.3 GA-stabilisierte PIN-Proteine verhindern die Insertion de novo synthetisierter PIN-Proteine an der Plasmamembran ....................................................... 56

4.4 Synergistische Wirkung von GA und Auxin auf das Auxinmaximum in der Wurzelspitze und das Wurzelwachstum

4.5 Die GA-Biosynthese Mutante gal-3 zeigt geringere Auxingehalte und verminderte Sensitivität gegenüber exogen appliziertem Auxin in der Wurzel

5. Material und Methoden (zusätzliche Ergebnisse) .......................................6 60

5.1 Wachstumsbedingungen und pharmakologische Behandlungen ....................60

5.2 RNA Isolation, cDNA Synthese und quantitative RT-PCR ...........................60

5.3 Quantifizierung des akropetalen Auxintransports in der Wurzel................... 61

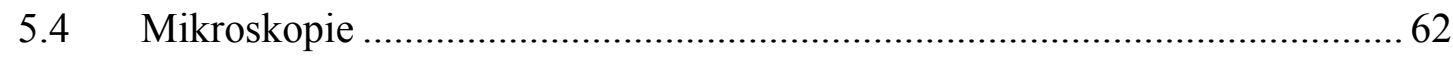

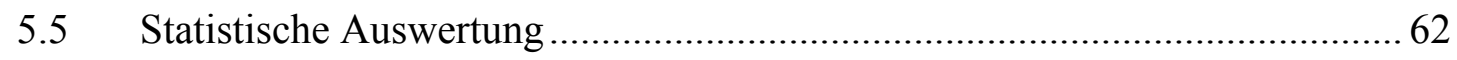

6. Zusammenfassung der zusätzlichen Ergebnisse ........................................63

7. Diskussion des Manuskripts und der zusätzlichen Ergebnisse ....................... 64 
7.1 Während der gravitropen Krümmungsreaktion beeinflusst asymmetrische GAVerteilung die Etablierung des Auxingradienten.......................................... 64

7.2 GA moduliert die Balance zwischen PIN-Abbau und PIN-Recycling ........... 66

7.3 GA und seine Wirkung auf den Auxintransport ..........................................69

7.4 GA wirkt über die Beeinflussung des Auxingehalts auf das Wurzelwachstum

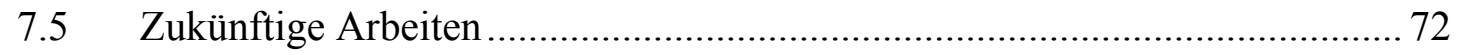

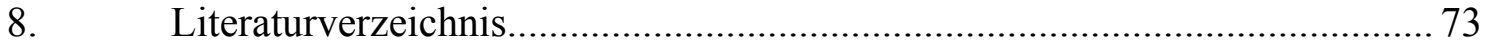

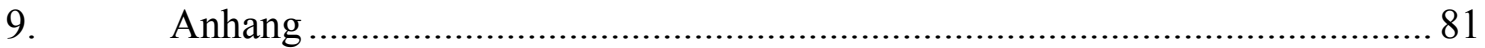

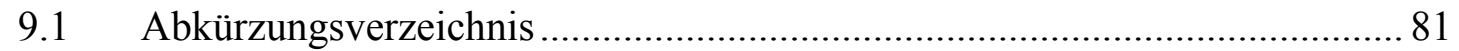

9.2 Verwendete synthetische Oligonukleotide................................................... 83

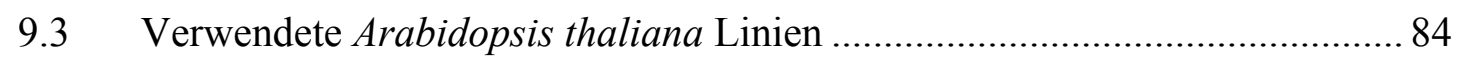

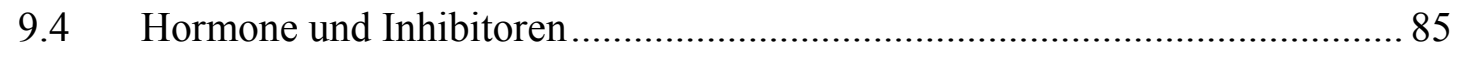

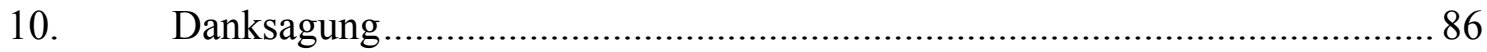

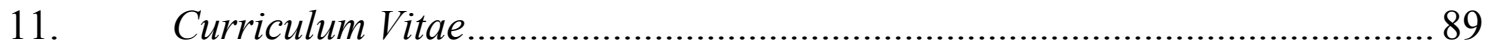




\section{Einleitung}

Gestalt, Entwicklung und Funktion eines vielzelligen Organismus beruhen auf effizienter Kommunikation zwischen den einzelnen Zellen und Organen. Pflanzen verfügen nicht über ein dem Nervensystem der Tiere vergleichbares System, und Hormone sind in Pflanzen maßgebliche Regulatoren bei der Pflanzenentwicklung und der Verarbeitung biotischer und abiotischer Reize. Hormone sind chemische Regulationsfaktoren, die als kleine Moleküle vorkommen und bereits in geringen Konzentrationen ihre Wirksamkeit zeigen.

Der Grundstein zur Hormonforschung in Pflanzen wurde schon 1881 in dem Buch „The Power of Movement in Plants" von Charles und Francis Darwin gelegt, in dem die phototrope Krümmung von Avena sativa Keimlingen beschrieben wurde. Fast 50 Jahre später zeigten Cholodny und Went, dass es ein mobiles Signal geben musste, das für die Krümmung der Koleoptile verantwortlich ist und das durch einseitige Applikation eine differentielle Zellstreckung hervorrufen kann (Went, 1926). Diese chemische Substanz wurde von Went Auxin nach dem griechischen Wort $\alpha v \xi \alpha v \omega$ (vermehren, wachsen) benannt und später als Indol-3-essigsäure (IAA) identifiziert (Kogl et al., 1934).

\subsection{Auxin}

In der Pflanze kommen neben IAA auch andere Auxine vor wie z.B. Indol-3Buttersäure (IBA), Phenylessigsäure (PAA) oder 4-Chlor-IAA (4 Cl-IAA). In der Landwirtschaft werden synthetische Verbindungen mit Auxinwirkung verwendet, die sich oft durch eine höhere Stabilität auszeichnen und als Bewurzelungshilfe oder Herbizid eingesetzt werden. Hauptsyntheseort von Auxin in der Pflanze sind die meristematischen Gewebe von Spross-Apex, Blättern, Blüten, oder sich entwickelnden Samen. Auxine leiten sich chemisch von der Aminosäure Tryptophan ab und werden hauptsächlich aus diesem Vorläufer synthetisiert (Bartel, 1997). Dennoch gibt es auch einen Tryptophan-unabhängigen Syntheseweg, bei dem die Biosynthese aus der Tryptophanvorstufe Indol-3-Glycerinphosphat erfolgt. Der Großteil des Auxins liegt im Pflanzengewebe biologisch inaktiv vor und ist über die Carboxylgruppe esterartig an myo-Inositol, Aminosäuren, Peptide oder Zucker konjugiert. Diese inaktiven Konjugate 
dienen wahrscheinlich zur Aufrechterhaltung der Auxinhomöostase oder als Speicherform (Woodward und Bartel, 2005). Durch Hydrolyse kann konjugiertes Auxin aktiviert werden (Bartel und Fink, 1994). Auxinabbau erfolgt durch direkte Oxidation freien IAAs oder mit Asparaginsäure konjugierten IAAs (IAA-Asp). Konzentrationsabhängig verschiebt sich der Anteil von direkter Oxidation von freiem Auxin in Richtung IAA-Asp-Abbauroute bei erhöhten endogenen Auxingehalten (Ostin et al., 1998).

\subsubsection{Auxintransporter und ihre Verteilung}

Es ist mittlerweile anerkannt, dass nicht nur die Auxinbiosynthese (Petersson et al., 2009), sondern auch der gerichtete Auxintransport von Zelle zu Zelle essentiell ist, um IAA-Maxima oder -Minima $\mathrm{zu}$ erzeugen und aufrecht $\mathrm{zu}$ erhalten, die für die Entwicklung und Adaption innerhalb der Pflanze nötig sind (Galweiler et al., 1998; Friml et al., 2002a; Benkova et al., 2003; Friml et al., 2003; Sorefan et al., 2009).

Bei niedrigerem $\mathrm{pH}-$ Wert $(\mathrm{pH} 5,5)$ im Apoplasten als im Symplasten $(\mathrm{pH} 7,0)$ liegt Auxin hauptsächlich als protonierte Form vor, so dass es über die Plasmamembran ins Zytoplasma diffundieren kann. Dort wird es aufgrund des höheren $\mathrm{pH}$-Wertes deprotoniert und kann als IAA ${ }^{-}$die Zelle dann nicht mehr passiv verlassen (Abb. 1). Da der passive IAAInflux nicht für den Auxintransport gegen bestehende Gradienten ausreicht, können Proteine aus der AUX1/LAX Familie den Transport unterstützen (Bennett et al., 1996; Swarup et al., 2008). Sie dienen als $\mathrm{H}^{+} / \mathrm{IAA}^{-}$Symporter (Yang und Murphy, 2009) und sind je nach Zelltyp symmetrisch oder

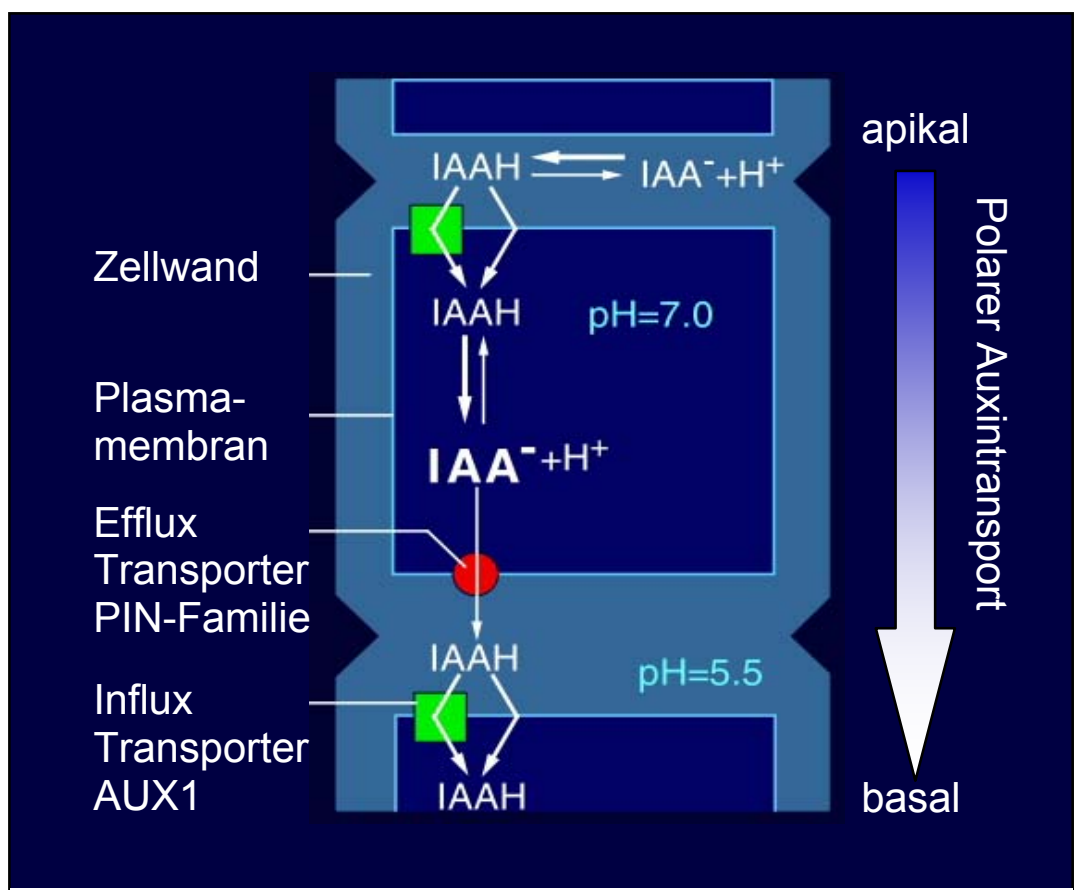

Abb. 1: Schematische Darstellung der Chemiosmotischen-Hypothese des polaren Auxintransports (nach Rubery und Sheldrake, 1974). Auxin wird von AUX1 in protonierter Form an der apikalen Seite einer Zelle aus dem Apoplasten ins Zellinnere transportiert. In der Zelle diffundiert ungerichtet das deprotonierte Auxin durch das Zytoplasma und polar verteilte PIN-Proteine vermitteln den Export in den Apoplasten am Übergang zur nächsten Zelle. 
asymmetrisch, aber in den meisten Fällen gegensätzlich zu PIN lokalisiert, um eine gerichtete Transportrichtung zu ermöglichen. Das Zusammenwirken von Influx- und Effluxtransportern ist in der „chemiosmotischen Hypothese“ (Rubery und Sheldrake, 1974; Goldschmith, 1977) zu dem gerichteten, polaren Transport auch gegen Konzentrationsgradienten formuliert worden. In höheren Pflanzen wie z.B. Arabidopsis thaliana gibt es mehrere Influx- und Efflux-Transporter, die an der Plasmamembran lokalisieren und unabdingbar für den interzellularen Auxintransport sind. Dem IAAInflux durch Diffusion oder AUX1/LAX Proteine steht der IAA-Efflux entgegen, der durch P-Glykoproteine (PGP) und PIN-Formed (PIN)-Proteine geleistet wird (Delker et al., 2008).

Die Gruppe der P-Glykoproteine (PGP) aus der ABCB-Transporter-Familie beinhaltet als bestcharakterisierteste Mitglieder die Proteine PGP1, PGP4 und PGP19, die sowohl in pflanzlichen als auch heterolog in tierischen Zellen exprimiert, IAA exportieren können (Geisler et al., 2005; Petrasek et al., 2006; Cho et al., 2007). Sie sind vor allem unpolar in der Plasmamembran lokalisiert und es wird angenommen, dass sie der Rückdiffusion von IAAH nach dem Herauschleusen durch Efflux-Transportern entgegen wirken (Mravec et al., 2008). Hierdurch wird der polare Auxintransport unterstützt. Weiterhin interagieren PGP-Proteine mit PIN-Proteinen und bestimmen die Substratspezifität des Transports für IAA (Blakeslee et al., 2007; Titapiwatanakun et al., 2009). Benzoesäure (BA) wird in Transportversuchen gewöhnlich als Kontrolle eingesetzt, da sie als schwache organische Säure in ihren Eigenschaften dem Auxin ähnelt, aber dennoch nur in geringen Mengen transportiert wird (Geisler et al., 2005). So konnte sowohl bei heterologer Expression von PIN und PGP in tierischen Zellen, als auch in planta gezeigt werden, dass der BA-Transport nur bei gemeinsamer Expression von PGP- und PIN-Proteinen unterdrückt war (Blakeslee et al., 2007).

Die aus der Familie der PIN-Formed (PIN) stammenden Proteine ermöglichen sowohl im pflanzlichen als auch in heterologen Systemen Auxin-Efflux (Petrasek et al., 2006; Yang und Murphy, 2009) und können apikal, basal oder lateral verteilt sein, in Abhängigkeit vom jeweiligen PIN-Protein, Zelltyp oder Entwicklungskontext. Die acht in Arabidopsis vorkommenden PIN-Proteine besitzen eine charakteristische hydrophile Mitteldomäne, die zwei hydrophobe Bereiche aus jeweils 4-5 Transmembrandomänen trennt. Durch die Länge der hydrophilen Domäne bestimmt, lassen sich die PINProteine in zwei Unterklassen aufteilen: den Typ 1 (PIN1, PIN2, PIN3, PIN4 und PIN7) mit einem längeren hydrophilen Bereich, und Typ 2 (PIN5, PIN6 und PIN8) mit einem 
kürzeren hydrophilen Bereich (Mravec et al., 2009). Die intrazellulare Lokalisierung der PIN-Proteine ist durch ihre jeweiligen hydrophilen Bereiche vorgegeben, wodurch Typ 1 PIN-Proteine mit der Plasmamembran assoziiert sind, jedoch Typ 2 Proteine mit dem Endoplasmatischen Reticulum (ER) in Verbindung gebracht werden. Die PINVerteilung im Pflanzengewebe hängt nicht von der Zuordnung zu Typ 1 oder Typ 2, sondern vielmehr von dem einzelnen PIN-Protein und dessen Expressionsort ab. So lokalisiert PIN1 apikal in der Epidermis von Spross-Apexen, Embryonen und Gynoecia, während es im Leitgewebe von Embryonen, Blättern, Stängeln und Wurzeln basal verteilt ist (Galweiler et al., 1998; Benkova et al., 2003; Friml et al., 2003; Sorefan et al., 2009). Durch die basale Lokalisierung von PIN-Proteinen wird im oberen Teil der Pflanze synthetisiertes Auxin in Richtung Wurzel transportiert. Eine laterale Verteilung wird vor allem durch PIN3 vermittelt, welches auf der inneren Seite der SprossEndodermiszellen $\mathrm{zu}$ finden ist und den Auxinstrom in das vaskulare Leitgewebe zurückführt (Friml et al., 2002a; Zadnikova et al., 2010). In den Columellazellen der Wurzelhaube, in denen auch PIN4 und PIN7 lokalisiert sind, liegt PIN3 apolar vor (Kleine-Vehn et al., 2010) und lenkt den Auxinstrom in die lateralen Bereiche der Wurzelhaube um. PIN2 ist apikal in der lateralen Wurzelhaube und den Epidermiszellen lokalisiert. In den Cortexzellen der Wurzel ist PIN2 hingegen basal lokalisiert und somit mitverantwortlich für die Auxinzirkulation und die Aufrechterhaltung des Auxinmaximums in der Wurzelspitze (Müller et al., 1998) (Abb. 2 A, B). Die übrigen PIN-Proteine des Typs 2 finden sich in der ER-Endomembran und für PIN5 konnte gezeigt werden, dass es den intrazellulären Auxintransport und die Auxinhomöostase mitreguliert (Mravec et al., 2009).

Die polare Verteilung von PIN-Proteinen hängt von ihrem gezielten intrazellulären Transport $\mathrm{ab}$, der durch den Phosphorylierungsstatus der Proteine bestimmt wird. So konnte durch eine Mutation im Mittelteil des hydrophilen Bereichs von PIN1 eine Veränderung der Lokalisierung von basal zu apikal verursacht werden (Wisniewska et al., 2006). Die Ser/Thr Protein Kinase PINOID (PID) kann direkt in vivo und in vitro diesen hydrophilen Bereich phosphorylieren wobei die Protein Phosphatase 2A (PP2A) dazu antagonistisch wirkt (Michniewicz et al., 2007). Ein hoher Grad an PIN-Phosphorylierung, der entweder durch Überexpression von PID (Friml et al., 2004) oder durch Hemmung von PP2A (Michniewicz et al., 2007) erreicht werden kann, führt somit zu einer apikalen Lokalisierung von PIN1 (Friml et al., 2004; Michniewicz et al., 2007). 


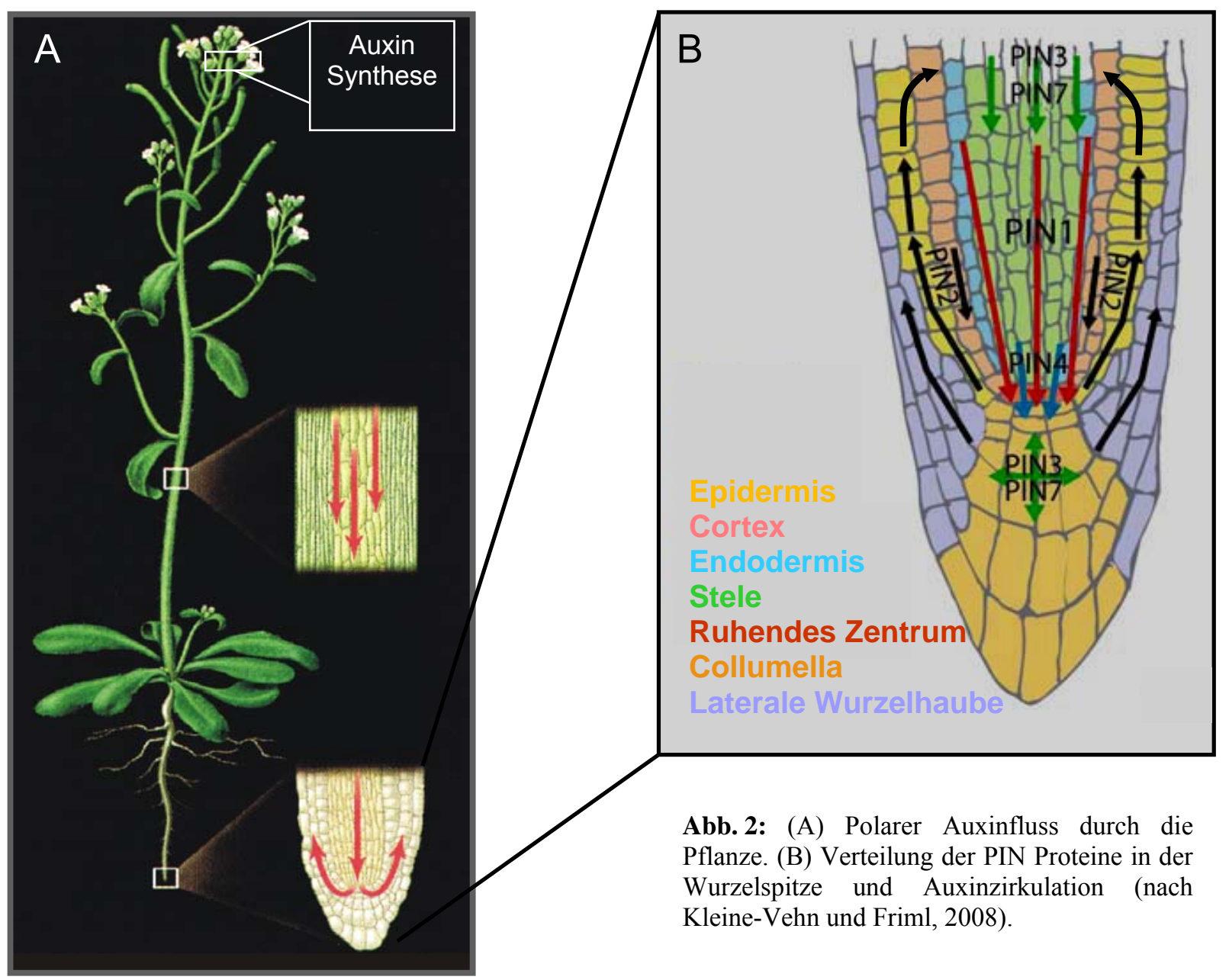

\subsubsection{Intrazelluläre Migrationswege (Endomembranfluss)}

PIN-Proteine sind Transporter und somit integrale Membranproteine. Sie werden im ER synthetisiert und mit dem Endomembranfluss zu und zwischen ihren Zielmembranen verteilt. Neu synthetisierte PIN-Proteine falten sich zunächst im ER. Hier werden auch die ersten Schritte der Glykosylierung vermittelt, bevor der weitere Transport zum Golgi-Apparat erfolgt. Der Golgi-Apparat besteht aus mehreren Zisternen und ankommende Vesikel wandern von der cis-Seite zur trans-Seite und gelangen zum ER abgewandten trans-Golgi-Netzwerk (TGN) (Jurgens, 2004). Am TGN werden Proteine sortiert und entweder auf den Weg zur Plasmamembran oder zur Vakuole gebracht (Viotti et al., 2010) (Abb.3). 


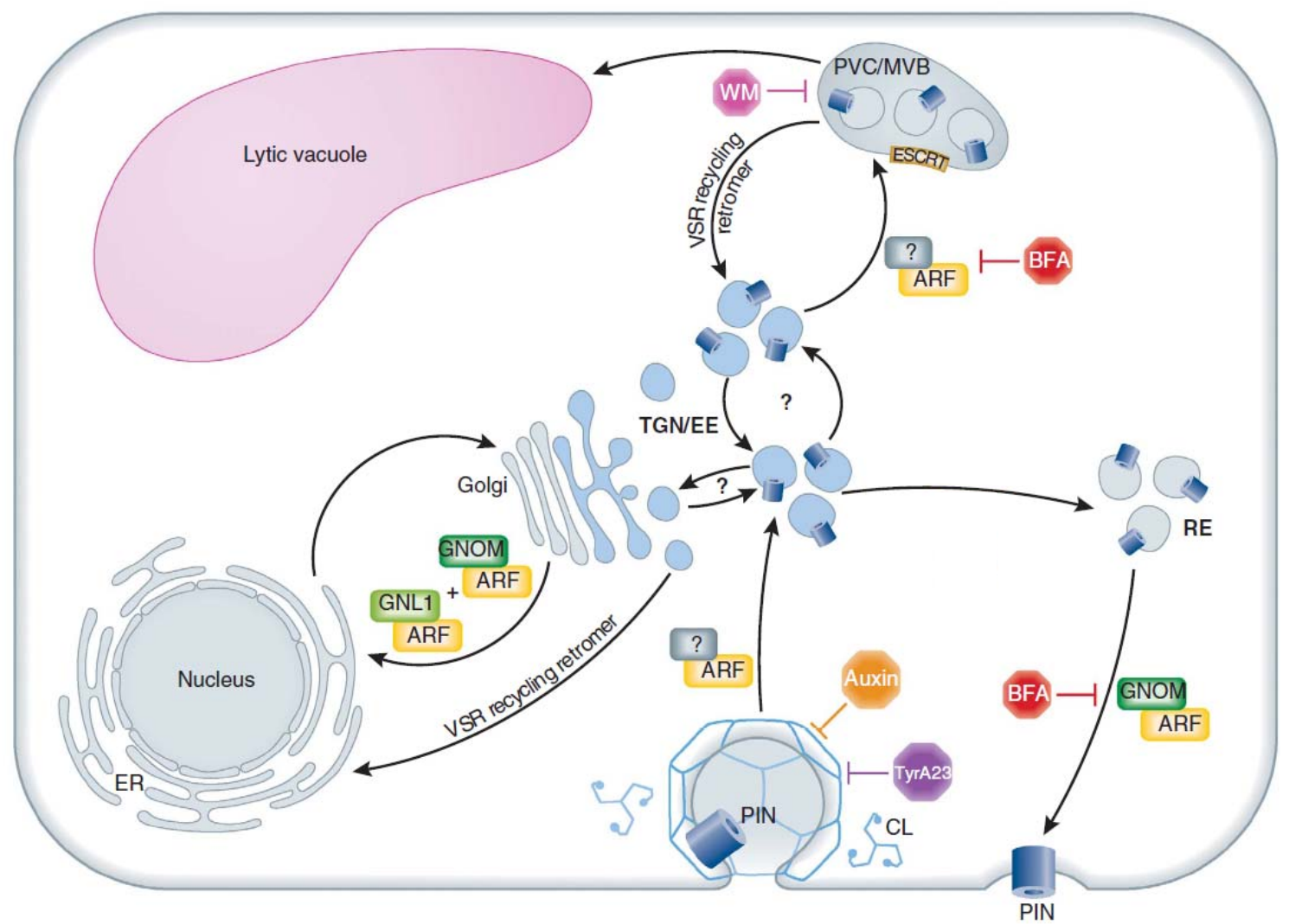

Abb. 3: Schematische Darstellung des subzellularen Membranflusses, der der Verteilung, Polarisation und Degradation von PIN-Proteinen zu Grunde liegt. BFA, Brefeldin A; EE, frühes Endosom; ER, Endoplasmatisches Reticulum; MVB, multi-vesicular bodies; PVC, pre-vakuoläres Kompartiment; RE, Recycling Endosom; TGN, Trans-Golgi Netzwerk; WM, Wortmannin (Grunewald und Friml, 2010).

Nach Erreichen ihrer Zielmembranen ist die Verteilung von PIN-Proteinen nicht abgeschlossen, sondern unterliegt dynamischen Recycling-Prozessen, die bei plasmamembranlokalisierten PIN-Isoformen durch Membraninternalisierung eingeleitet wird (Dettmer et al., 2006; Lam et al., 2007). Die endozytotische Migration von PINProteinen an der Plasmamembran beginnt mit der Bildung von Vesikeln, die Clathrinbeschichtet sind. Diese Vesikel fusionieren mit „frühen“ Endosomen die als eine Sortierungs- und Recycling-Station dienen (Abb. 3). Gerade Endosomen sind nicht statische, sondern müssen als dynamische Kompartimente betrachtet werden, die sich ständig verändern und entwickeln (Dettmer et al., 2006; Lam et al., 2007). In diesem komplexen System der „frühen“ Endosomen treffen der sekretorische und der endozytotische Weg zusammen (Abb. 3). „Späte“ Endosomen sind „multi-vesicular bodies“ (MVB) oder pre-vakuoläre Kompartimente (PVC) die wiederum als Sortierungsstation vor der lytischen Vakuole stehen (Robinson et al., 2008) und den 
Abbau sowie das Recycling von PIN-Proteinen regulieren (Abb. 3). Die lytische Vakuole ist äquivalent zum tierischen Lysosom, das als Kompartiment dem Abbau von Proteinen und der Speicherung von Degradationsprodukten dient. Es ist also wichtig festzuhalten, dass PIN-Proteine nicht statisch an der Plasmamembran vorliegen, sondern ständigen dynamischen endo- und exozytotischen Prozessen in der Zelle unterliegen (PIN-Cycling; Abb. 3).

Die beschriebenen Schritte des PIN-Cyclings können durch geeignete Farbstoffe und pharmakologische Agenzien sichtbar gemacht und beeinflusst werden. Beispielsweise ist mit Hilfe eines lipidbindenden Indikators (FM4-64) die Visualisierung der Endozytose möglich. FM4-64 lagert sich in die Plasmamembran und andere Membranen ein, fluoresziert erst in der hydrophoben Umgebung und markiert somit von der Plasmamembran stammende Vesikel (Vida und Emr, 1995). Die Schlussfolgerung, dass PINs nicht statisch an der Plasmamembran lokalisiert sind sondern fortlaufend internalisiert werden, beruhte u.a. auf der Beobachtung, dass fluoreszenzmarkierte PIN-Proteine mit FM4-64-markierten Vesikeln kolokalisieren (Paciorek et al., 2005; Jelinkova et al., 2010). Mit Tyrphostin A23 existiert ein Werkzeug, mit dem der Clathrin-abhängige endozytotische Schritt des PIN-Cyclings beeinflusst werden kann und demnach die Internalisation von PIN-Proteinen (Dhonukshe et al., 2007). Im tierischen System ist Tyrphostin A23 ein gut charakterisierter Inhibitor, der die Interaktion zwischen der Fracht Clathrinbeschichteter Vesikeln und den Adaptin-Proteinen stört, die das Rekrutieren der Ladung in die Vesikel vermitteln (Banbury et al., 2003). Durch pharmakologische Behandlung mit Brefeldin A (BFA) konnte gezeigt werden, dass PIN-Proteine von den Endosomen wieder zurück zur Plasmamembran bewegt werden, da die BFA-Behandlung zur PINAkkumulation in sogenannten BFA-Körpern führt, die nach Auswaschen des BFAs wieder abgebaut werden. Die PIN-Proteine nehmen dann wieder ihren angestammten Platz an der Plasmamembran ein (Geldner et al., 2001).

Die zyklische Bewegung der PIN-Proteine von der Plasmamembran zu den Endosomen und wieder zurück wird mit Hilfe von „ADP-ribosylation factors“ (ARFs) gesteuert, die essentiell für den intrazellularen Endomembranfluss sind. Sie vermitteln Entstehung, Verschmelzung und Richtung von Vesikeln, die Fracht zwischen intrazellulären Kompartimenten befördern. ARFs sind an der Oberfläche der Vesikelmembran lokalisiert, wo sie mit ihren Aktivatoren den ,guanin nucleotide exchange factors“ (GEFs) zusammentreffen (Donaldson und Jackson, 2000). Ein 
bekannter ARF-GEF in Pflanzen ist GNOM, der mit den „recycling“ Endosomen assoziiert ist und an dem Rücktransport von basal lokalisierten PIN-Proteinen zur Plasmamembran beteiligt ist (Abb. 3) (Geldner et al., 2003). GNOM ist BFA-sensitiv (Steinmann et al., 1999) und so ist sowohl in gnom-Mutanten, als auch nach pharmakologischer BFA Behandlung, PIN hauptsächlich in der basalen Lokalisierung gestört (Kleine-Vehn et al., 2008b). Da die AUX1 Lokalisierung in gnom-Mutanten nicht verändert ist (Fischer et al., 2006; Kleine-Vehn et al., 2006), AUX1 aber in BFAKörpern akkumuliert (Grebe et al., 2002), liegt die Annahme nahe, dass es für AUX1 einen ARF-GEF vermittelten BFA-sensitiven, aber GNOM-unabhängigen Weg geben muss. Bestätigt wird dies durch eine BFA-insensitive GNOM Variante, in der unter anderem die PIN2-Lokalisierung noch eingeschränkt BFA-sensitiv ist (Geldner et al., 2003).

Die Fracht der Endosomen kann entweder zurück über den GNOM-abhängigen, BFA-sensitiven Weg in Richtung Plasmamembran, oder zum PVC kanalisiert werden. Das PVC fungiert wieder als eine Art Sortierungsstation für Proteine, die entweder zum Abbau in der lytischen Vakuole bestimmt sind, oder recycelt und in Richtung Plasmamembran transportiert werden. Wortmannin stellt einen effektiven Inhibitor der Phosphatidylinositol 3-Kinase dar, hemmt PVC-basierenden Endomembranfluss und führt zur Schwellung der PVCs (Emans et al., 2002; Oliviusson et al., 2006). Auch BFA kann den Transport vom Endosom zur Vakuole stören, was auf einen BFA-sensitiven ARF-GEF vermittelten Weg zwischen „frühen“ Endosomen und PVC schließen lässt (Kleine-Vehn et al., 2008a). Um Proteine zur Vakuole zu befördern, existieren in Pflanzenzellen sogenannte „vacuolar sorting receptors“(VSRs), die nach der Abgabe der Liganden recycelt werden (Seaman, 2005). Diesen Schritt vermittelt ein RetromerKomplex, der aus einem ,sorting nexin“ (SNX)-Dimer und aus einem „vacuolar protein sorting“ (VPS)-Trimer der Proteine VPS26, VPS29, VPS35 besteht (Bonifacino und Hurley, 2008) und in Pflanzenzellen auf der Oberfläche der PVCs lokalisiert ist (Jaillais et al., 2006; Oliviusson et al., 2006; Jaillais et al., 2007). Es wird gemutmaßt, dass die Retromer-Proteine SNX und VPS die Balance zwischen dem Abbau über die Vakuole und dem Recycling von PIN-Proteinen in der Pflanze regulieren (Kleine-Vehn et al., 2008a). 


\subsubsection{Gravitropismus}

Auxin ist ein so wichtiger Regulator bei einer Vielzahl von pflanzlichen Wachstumsund Entwicklungsprozessen, dass vorgeschlagen wurde, die Abkürzung für das essentielle Hormon IAA (Indole-3-acetic a acid) bedeute in Wirklichkeit, ,influences almost everything“" (Weijers und Jurgens, 2004). Ein Beispiel für eine gut charakterisierte auxinvermittelte physiologische Reaktion, die zur Pflanzenplastizität beiträgt, ist der Gravitropismus, der mit asymmetrischer Auxinumverteilung und differentieller Zellstreckung einhergeht.

Die Wahrnehmung des gravitropen Reizes in der Wurzel erfolgt in spezialisierten Zellen, den Statozyten, die stärkehaltige Amyloplasten enthalten, die Statolithen genannt werden. Die intrazelluläre Bewegung der Statolithen oder bei ihrer Umverteilung ausgeübte Druckänderungen vermitteln der Zelle Informationen über die räumliche Orientierung relativ zum Gravitationsvektor (Hejnowicz und Sievers, 1981). Die Perzeption dieses Reizes, der von den Statolithen ausgeht, ist bislang nicht im Detail geklärt. F-Aktin, in dem die Statolithen feinmaschig aufgehängt sind, könnte bei der Reizwahrnehmung eine Rolle spielen (Collings et al., 2001; Morita, 2010). Dennoch zeigen Versuche, bei denen das F-Aktin durch Latrunculin B inhibiert wurde, kontroverse Resultate, da sich eine Förderung der Krümmungsreaktion und der Sedimentierung zeigte (Hou et al., 2003; Hou et al., 2004). Gesichert ist, dass nach der Sedimentierung der Statolithen eine Umverteilung der vorher nicht polar orientierten PIN3-Proteine durch Transzytose auf die in Orientierung zum Gravitationsvektor neue Unterseite der Zelle erfolgt (Kleine-Vehn et al., 2010). Hierdurch wird die Richtung des Auxinstroms auf die Wurzelunterseite umgelenkt. Diese resultierende asymmetrische IAA-Akkumulation führt aufgrund des niedrigeren Auxinoptimums der Wurzel zur Wachstumshemmung der Wurzelunterseite und folglich zur Reorientierung der Wurzelspitze nach unten. PIN2, das apikal in Epidermis und Cortex lokalisiert ist, verändert seine Polarisierung nicht wie PIN3, sondern unterstützt durch asymmetrische Verteilung die Umlenkung des Auxinstroms. Ermöglicht wird die Asymmetrie durch PIN2 Abbau in der lytischen Vakuole auf der dem Gravitationsvektor abgewandten Seite (Kleine-Vehn et al., 2008a). Die asymmetrische Auxinverteilung während des Gravitropismus ist sehr gut charakterisiert. Allerdings konnte die Konzentrationszunahme auf der Unterseite von Pflanzenorganen auch für andere Komponenten gezeigt werden. So lokalisierte nach Gravistimulation unter anderem Inositol 
1,4,5-Trisphosphat (Perera et al., 1999), ein möglicher Botenstoff, und später eine Saccharose-Synthase (Long et al., 2002) auf der neuen Unterseite. In Hordeum vulgare und Oryza sativa wurde nachgewiesen, dass ein weiteres klassisches Wachstumshormon, Gibberellin (GA), asymmetrisch, aber zeitversetzt verzögert zu Auxin, entlang des Gravitationsvektors akkumulierte (Cui et al., 2005; Wolbang et al., 2007). Die Wechselwirkung von GA und IAA ist bislang nur wenig untersucht worden und steht im Fokus der vorliegenden Arbeit.

\subsubsection{Auxinwechselwirkung mit der GA-Biosynthese und GA-Perzeption}

Der Wirkbereich eines Hormons wird oft isoliert nur im Kontext von Pflanzenwachstum und Entwicklung betrachtet; jedoch sind komplexe Vorgänge meist ein Ergebnis aus einer Vielzahl kombinierter Signale. Hierbei ist besonders wichtig zu beachten, dass Hormone ihre Biosynthese und/oder Perzeption gegenseitig beeinflussen können, so dass ein einem Hormon zugeschriebener Effekt möglicherweise von einem anderen Hormon vermittelt wird.

Ein Beispiel für die Vernetzung zweier Phytohormone ist die Beziehung von Auxin und GA. So fördert Auxin in A. thaliana die Transkription der Gibberellin 20-Oxidase 1 (GA20ox1), eines Schlüsselenzyms der GA-Biosynthese, und nimmt damit Einfluss auf den GA-Gehalt der Pflanze (Nemhauser et al., 2006). In Pisum sativum wurde die positive Wirkung von Auxin auf den GA-Gehalt in der Pflanze durch Entfernen der endogenen Auxinquelle gezeigt. Die gesunkenen GA-Gehalte konnten dann durch exogene Applikation von Auxin wieder komplementiert werden (Ross et al., 2000). Bei Hemmung des Auxintransports in der Wurzel wird die GA-Signaltransduktion negativ durch Wechselwirkung mit dem Abbau von DELLA-Proteinen beeinflusst (Fu und Harberd, 2003), die transkriptionelle Repressoren der GA vermittelten Antwort darstellen (Hartweck, 2008). DELLA-Proteine wurden nach dem Besitz des Aminosäuremotivs DELLA benannt (Peng et al., 1997). Die synergistische Wirkung von Auxin und GA wurde in Populus tremula $x$ tremuloides durch gleichzeitige Applikation der beiden Hormone untersucht. Dabei wurde gezeigt, dass der Auxingehalt des Stamms bei Behandlung mit IAA und GA stärker anstieg als bei alleiniger IAA-Gabe (Bjorklund et al., 2007). Da auch die PIN1-Transkription 
gesteigert wurde, postulierten Bjorklund et al. (2007), dass GA und IAA gemeinsam den Auxintransport fördern.

\subsection{Gibberelline}

Zur gleichen Zeit als Went seine Hafer-Koleoptile-Versuche durchführte, untersuchte der Japaner E. Kurosawa die Bakanae-Krankheit bei Reispflanzen ("verrückter Reis"), die sich in elongierten Internodien und dünnen Blättern äußert (Kurosawa, 1926). Verantwortlich war ein pflanzenpathogener Pilz, Gibberella fujikuroi, der bioaktives GA synthetisiert und somit diese Symptome verursachte (Phinney, 1983). Einige Jahre später konnte aus der Pilzkultur dann $\mathrm{GA}_{3}$ als erster Vertreter der Gibberelline isoliert werden (Yabuta, 1935).

\subsubsection{GA-Biosynthese und GA-Perzeption}

In Pflanzen existieren über hundert verschiedene Gibberelline, von denen $\mathrm{GA}_{1}, \mathrm{GA}_{3}$ (pilzlich) und $\mathrm{GA}_{4}$ nachweislich biologisch aktiv sind. Wie Auxine sind Gibberelline an einer Vielzahl physiologischer Prozesse beteiligt, wie z.B. der Blüten- und Samenentwicklung, der Samenkeimung, der Sprosselongation, der Blattentfaltung und der Kontrolle des Tagesrhythmus (Olszewski et al., 2002). Interessanterweise tritt der GA-Signalweg evolutionär gesehen erst sehr spät in Erscheinung. So werden ,alte“ zelluläre Prozesse wie die Zellelongation in Physcomitrella ohne Hilfe von GA reguliert, obwohl schon Teile der konservierten GA-Signaltransduktion vorhanden sind (Hirano et al., 2007; Vandenbussche et al., 2007; Yasumura et al., 2007).

Gibberelline sind Produkte des Sekundärstoffwechsels und werden aus der Terpenoidbiosynthese abgeleitet. Der erste Schritt der GA-Biosynthese wird von einer ent-Kauren-Synthase vermittelt und das entstehende Produkt wird dann weiter oxidiert (Yamaguchi, 2008). Dieser Schritt kann durch die synthetischen Pflanzenwachstumsregulatoren Paclobutrazol oder Uniconazol gehemmt und so die GA-Biosynthese unterbrochen werden (Izumi et al., 1985; Burden et al., 1987). Die weiterführenden Schritte von ent-Kauren zum biologisch aktiven GA werden von GA20-Oxidasen und GA3-Oxidasen übernommen. Die Inaktivierung erfolgt durch Umwandlung in $\mathrm{GA}_{8}$ oder $\mathrm{GA}_{34}$ mittels einer GA2-Oxidase (Abb. 4). 


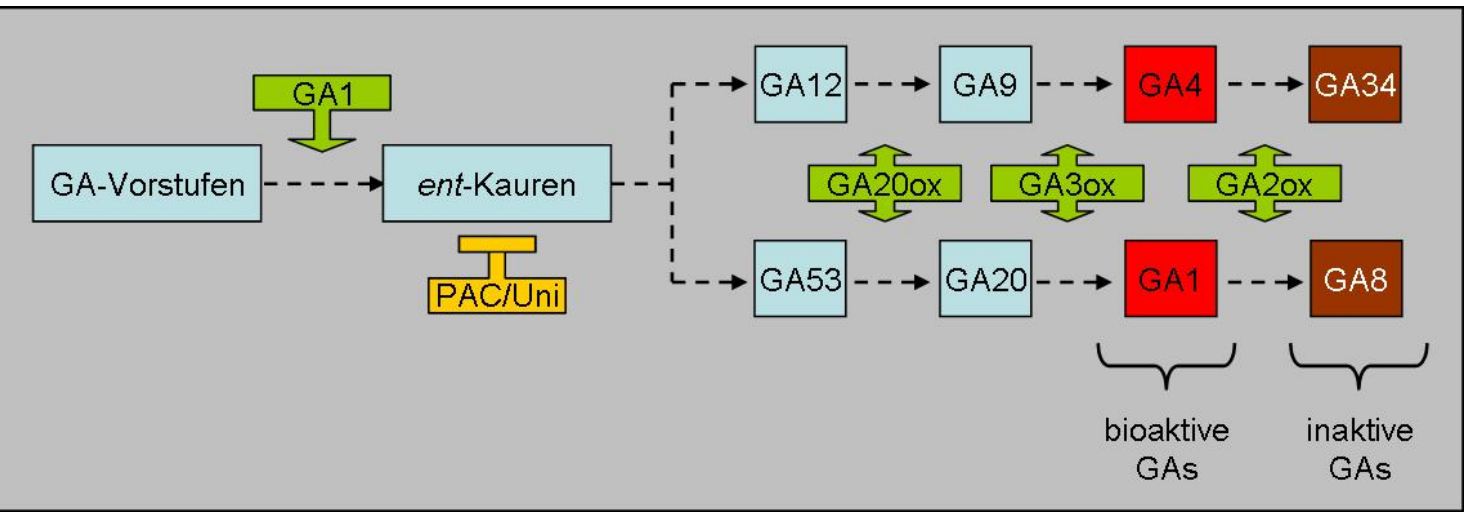

Abb. 4: Vereinfachte Darstellung der GA-Biosynthese in Pflanzen und deren Schlüsselenzyme (grün). Die GA-Vorstufen (blau) werden bis zum aktiven GA (rot) durch mehrere Schritte oxidiert und können durch weitere Oxidation wieder inaktiviert werden (braun). Paclobutrazol und Uniconazol (gelb) inhibieren Cytochrom P450-abhängige Monooxigenasen und somit die GA-Biosynthese (nach Yamaguchi, 2008).

Schlüsselkomponenten des GA-Signalwegs sind die kernlokalisierten DELLAProteine, transkriptionelle Repressoren, die GA-Antworten und das Wachstum unterdrücken (Peng et al., 1997; Dill und Sun, 2001; Silverstone et al., 2001). In Arabidopsis gibt es fünf DELLA-Proteine (Repressor of gal-3 [RGA], GA-insensitiv [GAI], RGA-LIKE1 [RGL1], RGL2 und RGL3), die zur Familie der GRAS-Proteine (benannt nach den ersten drei klonierten Mitgliedern GAI, RGA und SCL dieser Familie) gehören und ein konserviertes DELLA-Motiv in der N-terminalen Domäne gemeinsam haben (Bolle, 2004). DELLA-Proteine lassen sich verschiedenen physiologischen Prozessen zuordnen. So vermitteln RGA/GAI GA-abhängige Signale beim vegetativen Wachstum und der Blühinduktion, RGL2 bei der Samenkeimung und RGA/RGL1/RGL2 sind an der Blütenentwicklung beteiligt (Dill und Sun, 2001; Lee et al., 2002; Cheng et al., 2004). Die Entdeckung des nicht membranständigen GARezeptors war ein weiterer Meilenstein im Verständnis der GA-Signaltransduktion (Ueguchi-Tanaka et al., 2005). So unterdrücken die DELLA-Proteine in Abwesenheit von GA die Transkription GA-abhängiger Gene. Steigt die GA-Konzentration in der Zelle an, bindet der GA-Rezeptor GID1 an GA und kann aufgrund dessen mit DELLAProteinen interagieren. Dies führt zur Rekrutierung eines $\mathrm{SCF}^{\mathrm{GID}} / \mathrm{SLY}$-Komplexes, der die DELLA-Proteine ubiquitinyliert und damit ihren Abbau über das 26S-Proteasom induziert. Der Abbau des DELLA-Repressors ermöglicht dann die GA-vermittelte Genexpression (Abb. 5) (Ueguchi-Tanaka et al., 2007). 


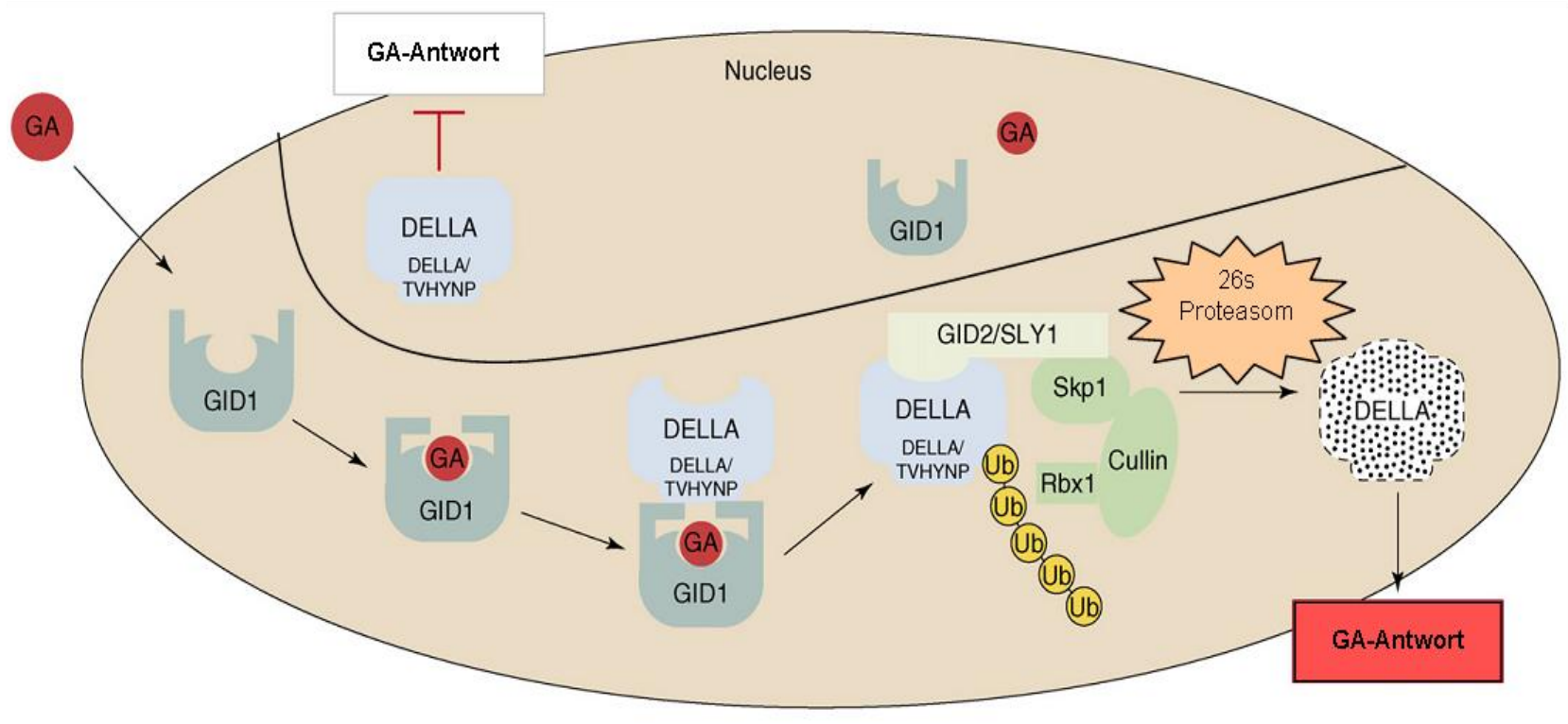

TRENDS in Plant Science

Abb. 5: Modell der GA-Signaltransduktion. In Abwesenheit von GA ist die transkriptionelle Antwort von GA unterdrückt. Bindet GA an den GA-Rezeptor (GID1) wird eine Interaktion mit DELLA Proteinen (RGA, GAI, RGL1-3) ermöglicht, was zu einer Degradation des Repressors durch das 26S Proteasom führt. Auf diese Weise werden GA-abhängige Gene aktiviert (nach Hirano et al., 2008).

Über den Wirkbereich und die Verteilung von GA in Wurzeln wird schon seit langem spekuliert. Bislang konnte nur mit Promotor-GUS-Fusionen von Genen der GABiosynthese auf den Syntheseort von GA geschlossen werden; eine direkte Darstellung der GA-Verteilung ist bislang nicht erfolgt (Silverstone et al., 1997; Mitchum et al., 2006; Desgagne-Penix und Sponsel, 2008; Yamaguchi, 2008). In der Wurzel sind GA1 und GA3ox2 in der Wurzelspitze, Zellteilungs- und Elongationszone lokalisiert, wobei GA3ox1 nur im Leitgewebe der Wurzel vertreten ist (Silverstone et al., 1997; Mitchum et al., 2006). GA20-Oxidasen sind nicht in der Wurzel, also nicht überlappend mit den anderen Biosynthesegenen, exprimiert, was auf einen Transport von Zwischenprodukten der GA-Biosynthese schließen lässt (Phillips et al., 1995). Da Reporterlinien der GABiosynthese nur indirekte Hinweise auf die GA-Perzeption in der Wurzel geben, wurde von Ubeda-Thomas et al. (2008) ein neuartiger Ansatz getestet, in dem die GASignaltransduktion durch gewebespezifische Expression einer dominant-negativen Variante von GAI unterbrochen wurde. Diese Experimente ergaben, dass die GAPerzeption in der Endodermis der Wurzel essentiell ist und den Taktgeber für die Elongation anderer Gewebe darstellt (Ubeda-Tomas et al., 2008; Ubeda-Tomas et al., 2009). Bisher ist jedoch nur ein sehr lückenhaftes Wissen der GA-Biosyntheseorte, des 
Transports von GA oder GA-Vorstufen und des GA-Wirkbereichs vorhanden. Es war ein Anliegen der vorliegenden Arbeit, die Wirkbereiche von GA näher einzugrenzen.

\subsection{Zielsetzung}

Der Gravitropismus stellt ein ideales System zur Analyse dynamischer Prozesse in der Pflanze dar und ist durch die Vielzahl vorhandener Werkzeuge, wie Mutanten und Reporterlinien, im Hinblick auf Auxin schon gut charakterisiert. Es ist allerdings anzunehmen, dass ein so komplexer Prozess wie der Gravitropismus nicht nur von einem Hormon, sondern von einem ganzen Netzwerk verschiedener Signaltransduktionskaskaden gesteuert wird, die miteinander verwoben sind und interagieren. Durch vorangegangene Arbeiten gibt es Hinweise, dass GA zumindest in oberirdischen Organen monokotyler Pflanzen ähnlich wie Auxin eine durch Gravistimulation induzierte asymmetrische Verteilung zeigt.

Im Rahmen dieser Arbeit sollte untersucht werden, ob es eine Vernetzung der beiden Wachstumshormone IAA und GA im Kontext des Gravitropismus in der Wurzel gibt. Dafür sollte mittels pharmakologischer und genetischer Manipulation der internen GA-Gehalte und der GA-Signaltransduktion unter anderem der generelle Einfluss von GA auf die Krümmungsreaktion in der Wurzel untersucht werden. Mit Hilfe der Reporter Linie DR5::GFP, die indirekt die Visualisierung der Auxinverteilung im Pflanzengewebe ermöglicht, sollte der Einfluss von GA auf Auxinmaxima in der Wurzel charakterisiert werden. Des Weiteren sollte die mögliche Wechselwirkung von GA mit der PIN-Transkription und dem dynamischen PIN-Endomembranfluss quantifiziert werden. Die physiologische Relevanz möglicher PIN-Veränderungen sollte durch Auxintransport-Versuche gestützt werden. Zur Überprüfung einer möglichen asymmetrischen GA-Verteilung auch im Wurzelgewebe während der gravitropen Krümmungsreaktion, sollte ein neuer Antikörper gegen GA etabliert werden, um die endogene GA-Verteilung in der Wurzel zu visualisieren. Unterstützend stand eine GAsensitive Reporterlinie, $R G A:: R G A-G F P$, zur Verfügung, in der der GA-vermittelte Abbau des Reportes in Arabidopsis Wurzeln untersucht werden sollte. 


\section{Manuskript}

\section{Gibberellin modulates root gravitropism via regulation of PIN stability}

Christian Löfke ${ }^{1}$, Marta Zwiewka $^{2}$, Jiří Friml ${ }^{2 *}$, Ingo Heilmann ${ }^{3}$, Thomas Teichmann ${ }^{1 *}$

\section{Running title: GA-auxin cross talk for gravitropism}

${ }^{1}$ Department of Plant Cell Biology, Albrecht-von-Haller-Institute of Plant Sciences, Untere Karspüle 2, Georg-August-University Göttingen, 37073 Göttingen, Germany ${ }^{2}$ VIB Department of Plant Systems Biology, Ghent University, Technologiepark 927, 9052 Gent, Belgium

${ }^{3}$ Department of Cellular Biochemistry, Martin-Luther-University Halle-Wittenberg, 06120 Halle (Saale), Germany

*To whom correspondence should be addressed:

Jiř́ Friml

VIB Department of Plant Systems Biology

Ghent University, Technologiepark 927

9052 Gent, Belgium

phone: +32-9-33 13913

fax: +32-9-33 13809

e-mail:jiri.friml@psb.ugent.be

Thomas Teichmann

Albrecht-von-Haller-Institute of Plant Sciences

Department of Plant Cell Biology

Untere Karspüle 2

D-37077 Göttingen, Germany

Phone: + 49 (0) 5513912844

Fax: + 49 (0) 5513910406

e-mail: tteichm@gwdg.de

Estimate of the length of the published article: 11 printed pages

The author responsible for distribution of materials integral to the findings presented in this article in accordance with the policy described in the Instructions for Authors (www.plantcell.org) is: Thomas Teichmann (tteichm@gwdg.de), Department of Plant Cell Biology, Albrecht-von-Haller-Institute of Plant Sciences, Untere Karspüle 2, Georg-August-University Göttingen, 37073 Göttingen, Germany 
Abstract

Gravitropic bending of plant organs is mediated by formation of an auxin gradient between the upper and lower side of the respective organ. Studies in monocot shoots suggested that besides auxin also gibberellin (GA) shows asymmetric distribution during gravitropism, but the functional relevance of this observation remains unclear. Here we addressed a role of GA in root gravitropism of Arabidopsis thaliana by genetically and pharmacologically manipulating GA metabolism and signaling. We show that manipulations of GA content and response in the root affect both auxin distribution during gravitropism and gravitropic response. Immunostaining using an antibody directed against GA detected asymmetry of GA distribution in the root tip during the gravitropic response. We observed that GA treatments specifically increased plasma membrane amounts of PIN auxin transporters independent of transcriptional regulation suggesting that GA affects root auxin distribution by stabilization of the gravitropic regulator PIN2. Manipulations of GA levels or GA signaling affected intracellular PIN2 accumulation in response to the trafficking inhibitor Brefeldin A. We propose that the observed increase in PIN2 stability may be due to a GA effect on the retromer complex causing enhanced recycling of PIN2 from the prevacuolar compartment to the trans-Golgi network with the consequence of less PIN2 trafficking to the lytic vacuole.

\section{Introduction}

Auxin and gibberellin (GA) are classical growth hormones and both have been originally identified by their obvious effects on elongation growth. The first experimental system to characterize auxin activity was based on auxin-induced elongation of Avena coleoptiles (Went, 1926). GA, on the other hand, was isolated from the fungus Gibberella, the cause of "foolish seedling disease" characterized by extremely elongated stem internodes in rice plants (Phinney, 1983). The longer lag time of GA-stimulated growth as compared with the lag time of auxin effects suggests different underlying mechanisms for regulation of cell expansion by these two hormones.

Cell elongation plays not only a role in general growth but is specifically important for plant tropistic responses which are accomplished by asymmetric growth of plant organs. Following a gravitropic stimulus, auxin distribution is changed in stem and root tissues resulting in a higher auxin accumulation at the sides of organs oriented 
towards the gravity vector (lower sides) (Muday, 2001). In the stem the increased auxin concentration causes upward bending due to a positive effect of higher auxin concentrations on cell elongation, while roots, having their auxin optimum at a lower concentration (Tanimoto, 2005), show inhibition of cell elongation and as a consequence roots bend downwards (Hasenstein and Evans, 1988). The gravity-induced changes in auxin distribution are mediated by polar, cell-to-cell auxin transport, dependent on activity of AUX1/LAX influx carriers (Bennett et al., 1996; Swarup et al., 2008) PIN efflux carriers (Gälweiler et al., 1998; Petrasek et al., 2006) and ABCB auxin transporters (Noh et al., 2001; Geisler et al., 2005; Blakeslee et al., 2007; Friml, 2010). PIN auxin efflux carriers show polar subcellular localization that determines directionality of intercellular auxin flow (Friml et al., 2004; Wisniewska et al., 2006). Thus, gravity-induced changes in the polarity of PIN localization as observed for PIN3 in root columella cells (Friml et al., 2002; Harrison and Masson, 2008) might provide a mechanism for initial redirection of auxin fluxes triggering root gravitropic bending. In addition to PIN3 polarity changes, also asymmetric PIN2 degradation on the upper versus lower side of the root is important for the gravitropic growth (Abas et al., 2006; Kleine-Vehn et al., 2008). Modifications in PIN localization and PIN protein amount are facilitated by changes of intra-cellular PIN trafficking. PIN proteins cycle between the plasma membrane and an endosomal compartment (Dhonukshe et al. 2007) and both its recycling back to the plasma membrane and trafficking to the vacuole are sensitive to brefeldin A (BFA), an inhibitor of ADP-ribosylation factor GTP-exchange factors (ARF-GEFs) (Geldner et al., 2001; Kleine-Vehn et al., 2008; reviewed in Kleine-Vehn and Friml, 2008). Starting from the endosome PIN proteins may traffic to different subcellular localizations or be routed via the prevacuolar compartment to the lytic vacuole for degradation. The rate of degradation can be modulated through retromer, a cytosolic coat complex involved in retrieving PIN proteins from the degradation pathway and recycling them back to the plasma membrane (Jaillais et al., 2007; Oliviusson et al., 2006; Jürgens and Geldner, 2007; Kleine-Vehn et al., 2008).

With respect to control of gravitropism, the focus of research has been on auxin and in particular its asymmetric distribution. However, many other factors play a role in gravitropism and concentration gradients along the gravitropic vector have also been reported for inositol 1,4,5-trisphosphate (Perera et al., 1999) and sucrose synthase (Long et al., 2002). Notably, in some monocot species including rice and barley, 
asymmetric accumulation of both auxin and GA at the lower side of gravistimulated organs has been reported (Cui et al., 2005; Wolbang et al., 2007).

The interaction of auxin and GA in regulation of gravitropic growth likely involves the coordinated cross-talk of the two plant growth regulators. Auxin has been shown to influence GA biosynthesis by increasing expression of GA20oxl, encoding a key enzyme of GA biosynthesis in Arabidopsis (Nemhauser et al., 2006). In addition, inhibition of auxin transport in Arabidopsis roots negatively affects GA signal transduction by interfering with degradation of DELLA proteins ( $\mathrm{Fu}$ and Harberd, 2003), transcriptional repressors regulating the GA response (Hartweck, 2008). Plants with reduced auxin transport or signaling showed a delayed degradation of the GFPtagged DELLA protein RGA after GA treatment in comparison with control plants (Fu and Harberd, 2003).

Here, we investigate a possible cross-talk of auxin and GA in regulating root gravitropic response. We show that GA modulation of root gravitropism correlates with GA-induced changes in the amount and distribution of membrane localized PIN proteins. Using a drug-free assay to visualize the impact of GA on PIN degradation in lytic vacuoles we demonstrate that GA regulates stability of PIN proteins providing a plausible mechanism for a GA effect on auxin distribution and tropistic growth.

\section{Results}

\section{GA is required for root gravitropic response}

We studied the effect of GA concentration changes and altered GA signal transduction on root gravitropism. To manipulate GA signaling and GA concentrations in the plant, we used genetical and pharmacological approaches (Figure 1A). Effects of elevated GA signaling were studied in the Arabidopsis pentuple mutants carrying lesions in all five DELLA repressors (Feng et al., 2008) and, therefore, GA signal transduction is permanently turned on in this mutant, mimicking high GA concentrations. Comparative analyses were done with wildtype seedlings treated with $50 \mu \mathrm{M}$ exogenous GA. Root responses to GA depletion were characterized in the GA biosynthetic gal-3 mutant with low endogenous GA concentrations (Sun and Kamiya, 1994) and results were compared to the gravitropic phenotype of seedlings treated with the GA biosynthesis inhibitor uniconazole. Positive manipulations with both GA levels and signaling as well as negative manipulations with GA levels, all reduced gravitropic responses of Arabidopsis roots (Figure 1B and C). Both, pharmacological treatments and genetic 
analyses showed the same pronounced effects on root gravitropism. These data show that balanced levels of GA and GA signaling are required for root gravitropic responses.

\section{GA is required for auxin distribution during root gravitropic response}

Auxin accumulates at the lower side of graviresponding organs including roots after gravitropic stimulation (Muday, 2001). This asymmetric auxin distribution is also reflected by increased activity of auxin response reporters such as DR5rev::GFP (Ulmasov et al., 1997; Friml et al., 2003; Ottenschläger et al., 2003) at the lower side of the root (Figure 2A). We used DR5rev::GFP to monitor a possible role of GA signaling on establishment of asymmetric auxin distribution in the root tip during the gravitropic response. Both, pharmacological and genetical manipulations with GA levels or signaling disturbed establishment of the asymmetric auxin distribution in the root tip following gravistimulation (Figure 2). Roots treated with GA failed to establish asymmetric DR5rev::GFP signal after gravistimulation and showed a symmetrically increased signal in the lateral root cap (Figure 2B) that was not detected in nonstimulated roots. On the other hand, inhibition of GA biosynthesis by uniconazole completely prevented lateral accumulation of DR5rev::GFP signal (Figure 2C). The data indicate that GA is involved in the establishment of an auxin gradient in the root tip, consistent with the effects of GA on root gravitropic response.

\section{Gravity stimulation induces asymmetric distribution of GA and GA response}

Based on published data showing asymmetric GA distribution after gravitropic induction of shoots in monocot species (Cui et al., 2005; Wolbang et al., 2007) and our observations of a GA role in root gravitropism we next tested whether gravitropic stimulation leads to changes in GA distribution. Since direct measurements of GA distributions are not feasible in Arabidopsis roots, we performed whole mount immuno analysis of root tips using an antibody raised against BSA conjugated GA. Control experiments with the antibody directed against GA showed unspecific binding of the secondary antibody to the lateral root cap but demonstrated specific binding of the primary antibody to epidermal cells of the cell division and elongation zones (Figure 3A, B). To confirm specificity of the anti GA antibody, additional experiments were carried out. The serum containing the antibody directed against GA was depleted of the GA specific antibody by incubating the serum with BSA-coupled GA prior to immunostaining experiments. This treatment drastically decreased the immune signal in 
the root epidermis and, therefore, showed that the antibody specifically detected GA in the epidermal cell layer of roots (Supplemental Figure 1 online). To proof that the antibody directed against BSA conjugated GA does not detect plant proteins related to BSA, an anti BSA antibody was used for control experiments. The anti BSA antibody did not cross react with plant proteins in the Arabidopsis root (Supplemental Figure 2 online). Increased signals after GA treatment but significantly weaker signals obtained with the gal-3 mutant or uniconazole-treated seedlings confirmed that we detect specific labeling of GA (Figure 3C and Supplemental Figure 3A-C online). Following gravistimulation, the GA-specific labeling revealed asymmetric GA distribution with stronger signal at the lower side of the root (Figure 3D and Supplemental Figure 3E- F online).

Since DELLA degradation depends on GA concentrations, we reasoned that changes in GA distribution can also be visualized by monitoring the GFP-tagged DELLA protein RGA-GFP. We observed a statistically significant $(P \leq 0,05)$ decrease of the RGA-GFP signal at the lower side of the root tip $3 \mathrm{~h}$ after gravistimulation (Figure 3E-G), indicating an increase of GA at the lower root side. Analysis of GA20ox1 expression during root gravitropism showed an initial decrease in GA20ox1 expression followed by upregulation of GA20ox1 expression (see Supplemental Figure 2A online) pointing to a general increase in root GA biosynthesis in response to a gravitropic stimulation unrelated to the moving of the seedlings to dark (see Supplemental Figure 4B online). Upregulation of the auxin responsive GH3.1 gene before induction of GA20oxl expression indicates a chronological order of changes in hormone distribution during gravitropism (see Supplemental Figure 4A online). GA concentrations seem to rise only after an initial increase of auxin concentration.

Notably, the asymmetric accumulation of GA in response to gravistimulation occurred in the cells where the key regulator of root gravitropism, the PIN2 auxin transporter is expressed as demonstrated by co-localization of GA antibody staining and PIN2-GFP localization (See Supplemental Figure 5 online). In summary, these observations show that following gravistimulation and establishment of auxin asymmetry, also a lateral GA gradient across the root is established as demonstrated by increased levels of GA and GA response at the lower side of the root. 


\section{GA increases PIN protein levels independent of PIN transcription}

The asymmetric auxin distribution during gravitropism requires activity of the auxin efflux carrier PIN2 (Luschnig et al., 1998; Wisniewska et al., 2006) that is an important component of root gravitropism (Luschnig et al., 1998; Müller et al., 1998). To test for a mechanism, by which GA is involved in root gravitropism, we studied effects of GA on PIN2 expression using PIN2::PIN2-GFP plants (Abas et al., 2006). GA-treated PIN2::PIN2-GFP showed a stronger signal at the plasma membrane (Figure 4A-B and G; Figure 9A and B) while uniconazole application caused a decrease in the GFP signal (Figures 4A, C and G). Comparative studies with PIN1-, 3-, 4-, and 7- GFP gave similar results (Supplemental Figure 6 online). Additionally, PIN2::PIN2-GFP line was crossed into the background of the GA biosynthetic mutant gal-3. The PIN2-GFP signal was decreased in PIN2::PIN2-GFP x gal-3 lines compared to controls and could be reconstituted to wild type levels by GA treatment (Figures 4D-F and I). Furthermore, the western blot analysis using anti-PIN2 antibody confirmed effects of GA on PIN2 levels in the root (Figure 4K). The dominant negative GA signaling mutant gaid17 expresses a GAI protein with truncated DELLA domain that is resistant to GA induced degradation and, therefore, constitutively suppresses GA signaling. Consistent with the data from roots of uniconazole treated seedlings and the gal-3 mutant the gaid17 seedling also contains lower PIN2 protein amounts compared to wildtype plants (Figure $4 \mathrm{~K})$. These results show that GA levels and signaling positively regulate abundance of different PIN proteins in the root.

Real time PCR analyses of GA-treated seedlings revealed no significant effects of GA on PIN2 transcription (Supplemental Figure 7), while a significant GA-induced decrease of GA20oxl expression showed that gene expression in the root was generally GA responsive (see Supplemental Figure 4C online). These results indicate that GA regulates PIN protein levels independently of PIN transcription and most likely stabilizes PIN proteins at the plasmamembrane. This conclusion was corroborated by analysis of TA::PIN2-GFP plants that allow dexamethasone inducible expression of PIN2. After dexamethasone induction of PIN2 expression in a TA::PIN2-GFP line for $24 \mathrm{~h}$, dexamethasone was washed out and seedlings were treated with GA and DMSO as control, respectively. The GA treatment drastically inhibited degradation of PIN2 proteins compared to controls (Figure 5).

Changes of auxin localization in the root tip have also been described as a response to ethylene treatment (Ruzicka et al., 2007). To test whether the observed increase of 
PIN2-GFP levels after GA treatment is mediated indirectly by increased ethylene production in root tissues, we combined GA treatment with inhibition of ethylene biosynthesis by silver ions. We did not observe a difference to the results obtained with GA-treated PIN2::PIN2-GFP plants (Supplemental Figure 8 online). These results show that GA positively regulates amounts of PIN proteins independently of regulation of PIN transcription.

\section{GA inhibits vacuolar trafficking-mediated PIN degradation}

The observed increase in protein stability after GA treatment seems to be specific for PIN proteins, since plasma membrane amounts of the auxin influx carrier AUX1 (Bennett et al., 1996), the auxin transporter P-glycoprotein19 (PGP19), (Blakeslee et al., 2007) and aquaporin PIP2 (Baiges et al., 2002) a plasma membrane protein not involved in auxin related processes, were not influenced by GA (see supplemental Figure 9 online). The data indicate that GA specifically influences the stability of PIN proteins at the plasma membrane.

PIN2 protein amount at the plasma membrane is regulated by a balance between vacuolar trafficking-mediated degradation and constitutive recycling back to the plasma membrane (Kleine-Vehn et al., 2008). Targeting of GFP-tagged proteins to the lytic vacuole can be visualized by inhibition of vacuolar degradation in the dark leading to accumulation of GFP in the vacuoles (Tamura et al., 2003). PIN2::PIN2-GFP plants kept in the dark showed a prominent vacuolar GFP signal in addition to the signal from plasma membrane localized PIN2-GFP protein (Figures 6A). In contrast, the vacuolar PIN2-GFP signal in GA-treated plants kept in the dark was not visible, while the PIN2GFP plasma membrane signal was notably increased (Figures 6B). Analysis of the fluorescence quantification profiles of GA treated and control roots clearly showed higher PIN2-GFP signals at the plasma membrane and no vacuolar signal after GA application (Figures 6A-B). Reciprocal sets of experiments in uniconazole treated and gal-3 mutant plants confirmed the GA effect on PIN2 vacuolar targeting. Under the conditions of low GA concentrations a significant PIN2-GFP signal was observed in the lytic vacuoles in contrast to untreated and wild type plants (Figures 7A-D). Time of dark treatment was optimized to avoid saturation of PIN2-GFP signals in uniconazole treated seedlings and gal-3 plants. As a consequence, vacuolar signals of controls (Figure 6A and Figure 7A and C) vary in intensity. Collectively, these experiments strongly suggest that GA influences PIN2 degradation by regulating the rate of its 
trafficking into the lytic vacuole, high GA levels inhibiting whereas low GA levels promoting PIN2 vacuolar trafficking.

\section{GA inhibits vacuolar PIN trafficking downstream of BFA action}

Next we tested, which step of the vacuolar trafficking pathway is affected by GA. To evaluate if GA-mediated increase of plasma membrane localized PIN protein is caused by a general effect of GA on endocytosis, we studied uptake of the endocytosis marker FM4-64 in gal-3 and pentuple mutants and after GA and uniconazole treatment. Changed GA concentrations or GA signaling did not influence uptake of FM4-64 as compared to untreated controls (see Supplemental Figure 10 online). These results show that GA does not act on endocytosis.

Following internalization from the plasma membrane, PIN proteins are in the endosomes sorted either for the recycling back to the plasma membrane or for further trafficking towards the vacuole (Kleine-Vehn and Friml, 2008). Both, the recycling and to lesser extent vacuolar trafficking are sensitive to the vesicle budding inhibitor BFA (Kleine-Vehn et al., 2008). We treated roots of PIN2::PIN2-GFP plants with GA followed by application of BFA. BFA treatment aggregates different types of endosomes (Geldner et al., 2001) and thus allows better visualization of the endosomal cargos including PIN proteins. GA treatment preceding BFA application to roots increased the PIN2-GFP signal in BFA bodies as compared to controls not treated with GA (Figures 8A-B). In contrast, low GA concentrations in the roots of the gal-3 mutant or uniconazole treated roots reduced the PIN2-GFP signal in BFA endosomes as compared to controls (Figures 8C-F). The observed increase of the PIN2-GFP signal in BFA endosomes further supports that GA influences PIN trafficking and suggests that GA inhibits vacuolar trafficking at or downstream of BFA-sensitive endosomes.

\section{SNX1 is an inevitable component of GA mediated PIN stabilization}

At the PVC sorting of membrane proteins towards the lytic vacuole or back to the plasmamembrane via retromer is controlled. Components of the retromer complex are SNX1 and VPS29 (Jaillais et al., 2006; Jaillais et al., 2007). In order to study the role of retromer for GA mediated stabilization of PIN proteins, we investigated the effect of GA on PIN2 protein amounts in a snx $1-1$ knock out line that is impaired in retromer dependent recycling of membrane proteins (Figure 9A and C)(Kleine-Vehn et al., 
2008). Analyses of GA treatments of a snx1-1 x PIN2::PIN2-GFP line showed that SNX1 is necessary for the GA effect on PIN2 protein stabilization (Figure 9).

\section{GA controls PIN stability downstream of PI3 kinase activity}

Wortmannin treatment affects endocytotic processes at steps before or at the prevacuolar compartment (PVC) by inhibition of phosphatidylinositol 3-kinase (PI3K) and elicits formation of so called "wortmannin compartments". Kleine-Vehn et al. (2008) reported interception of PIN2-GFP translocation to the lytic vacuole by wortmannin and deduced that PI3K activity is necessary for regulation of PIN protein trafficking to the lytic vacuole. We reasoned that GA treatment should decrease the PIN2-GFP signal in wortmannin compartments with the assumption that a target of GA activity involves endocytic steps before or at the PVC. However, we did not observe a change of the PIN2-GFP signal in wortmannin compartments of roots with altered GA concentration (see Supplemental Figure 11 online), suggesting that GA does not inhibit trafficking between early endosome/trans-Golgi network (TGN) and PVC (Figure 11).

\section{Decrease of GA levels and response restores 35S::PIN1 gravitropic growth}

To test the physiological relevance of GA regulation of PIN degradation, we made use of a line overexpressing PIN1 under the control of the 35S-promoter (Benkova et al., 2003). The $35 S: \because P I N 1$ roots show a severe agravitropic phenotype (Figure 10A) presumably due to the ectopic presence and apolar localization of PIN1 in the root epidermis cells (Wisniewska et al., 2006; Mravec et al., 2008). The down regulation of GA signaling in the dominant negative DELLA mutation gaid17 (Peng et al., 1997) or decrease of endogenous GA levels by uniconazole treatment of 35S::PIN1 seedlings lead to the increased degradation of PIN1 and decrease of ectopic PIN1 levels (Figure $10 \mathrm{D}$ and $\mathrm{E})$.

Notably, this decrease correlated with rescue of normal gravitropic growth in $35 S:: P I N 1 \times$ gai 17 or uniconazole-treated $35 S:: P I N 1$ roots (Figure 10B and C). Newly built adventitious roots showed a wildtype gravitropic orientation and the tips of agravitropically growing roots reoriented their growth towards the gravity vector (Figure 10C).

These observations further confirm the transcriptional regulation-independent GA effect on PIN stability and demonstrate that GA regulation of PIN stability has a physiological impact on root growth. 


\section{Discussion}

\section{Asymmetry of GA modulates auxin transport and distribution during root gravitropism}

Requirements for gravitropism are temporal asymmetry of growth induced by temporal asymmetry of auxin distribution. Auxin elevates GA biosynthesis in Arabidopsis by increased expression of the GA biosynthesis genes GA20ox1 and GA20ox2 (Frigerio et al., 2006) and accumulation of auxin on the lower side of a gravitropically induced root will presumably lead to a corresponding increase of GA concentrations. Recent publications from monocot species (Cui et al., 2005; Wolbang et al., 2007) and our results in Arabidopsis show that GA does in fact exhibit asymmetric distribution after gravitropic stimulation of plant organs. Due to GA-mediated stabilization of PIN2 protein (Figure 4), the observed increase of GA on the lower side of the root will increase PIN2 amounts at the plasma membrane, concurrent with enhanced PIN2 degradation on the upper side of the root as described (Abas et al., 2006; Kleine-Vehn et al. 2008). Our data suggest that re-routing of the auxin stream during gravitropism is not only achieved by a change of PIN3 localization and PIN2 degradation on the upper root side but, in addition, by a GA induced stabilization of PIN2 protein on the lower root side. The observed inhibition of root gravitropism by GA (Figure 1B and C) and the lateral DR5-monitored auxin response after GA treatment (Figure 2B) are most likely caused by the GA-induced increase of PIN2 protein amounts. As a consequence of higher PIN2 amounts, more auxin will be redirected from the root tip to the lateral columella cells causing an increase in auxin concentrations that is visualized by the lateral DR5rev::GFP signal. A general stabilization of PIN2 in the root tip will prevent or diminish PIN2 degradation on the upper side of the root during gravitropism and, therefore, inhibit the establishment of the auxin gradient necessary for gravitropic bending of the root (Figure 2B). In contrast, a decrease of GA contents in the gal-3 mutant or in roots treated with uniconazole will decrease PIN2 amounts and may then mimic the agravitropic pin2 mutant (Luschnig et al., 1998; Chen et al., 1998; Utsuno et al., 1998; Müller et al., 1998).

\section{GA specifically stabilizes PIN proteins}

The effect of GA on PIN2 protein amount is non-transcriptional (Figure 5, Supplemental Figure 7) and most likely involves stabilization of PIN2 protein by a GA- 
mediated change in intracellular trafficking of PIN proteins (Figure 11). Plasma membrane proteins targeted for degradation are endocytosed and subsequently hydrolyzed by proteases in the lytic vacuole after a passage through the early and late endosomes. Degradation rate of plasma membrane proteins may be regulated by retromer-dependent retrieval of proteins from vacuolar trafficking (Jaillais et al., 2007). During gravitropism, PIN2 is degraded on the upper side of the root during a defined time period and subsequently PIN2 protein levels recover back to normal involving the retromer complex with the core components SNX1 and VPS29 (Abas et al., 2006; Kleine-Vehn et al., 2008). We showed that GA did not generally affect uptake of the endocytosis marker FM4-64 and accumulation of PIN2-GFP in wortmannin bodies was not influenced by changes in GA concentrations or DELLA-signaling, but GA increased the PIN2-GFP signal in the so called BFA bodies mainly consisting of early and recycling endosomes (Figure 8). We conclude that GA does not interfere with steps of the retrograde trafficking before the PVC suggesting that GA might modulate PIN2 retrograde transport from the PVC to the early endosome/TGN. Our conclusions are supported by the observation that the effect of GA on PIN protein stabilization depends on the retromer component SNX1 (Figure 9). The data on the stabilizing effect of GA on PIN proteins are corroborated by the characterization of the double mutant 35S::PIN1 x gai 17. Ectopic expression of PIN1 under the control of the 35S promoter results in basal/lower side localization of PIN1 in root epidermis cells (Wisniewska et al., 2006) opposite to PIN2 showing apical/upper side orientation. Presumably the antipodal orientation of two PIN proteins in root epidermis cells causes the severe agravitropic phenotype of $35 S:: P I N 1$ seedlings. Interference with GA signaling by introgression of the dominant negative allele gai or treatments with the GA biosynthesis inhibitor uniconazole decrease PIN1 protein amounts by enhanced degradation and reestablish gravitropism (Figure 10).

In conclusion, we propose that GA increases PIN2 stability by enhancing PIN2 recycling from the PVC to the early endosome/TGN through interaction with the retromer complex (Figure 11). GA is a factor involved in late steps of gravitropism after the initial auxin gradient has been established. Based on the different kinetics of auxin and GA effects on cell elongation, auxin may control the early response of the root to a gravitropic stimulus and GA subsequently maintain gravitropic curvature by consolidating the auxin stream along the lower side of the root. The emerging picture involves GA as a part of the complex network controlling asymmetric phytohormone 
distribution during gravitropic responses. Future studies of the GA effects on PIN stability will elucidate mechanisms regulating cellular PIN trafficking and stability.

\section{Methods}

\section{Plant Material and Growth Conditions}

Seeds were surface sterilized with $70 \%$ ethanol supplemented with $0.05 \%$ Tween and dried on sterile filter paper. Plants were grown vertically on $1 / 2$ Murashige and Skoog including vitamins (MS) (Duchefa) with 1\% sucrose, $0.5 \mathrm{~g} / \mathrm{L}$ MES and $\mathrm{pH} 5.7$ under a $16 \mathrm{~h} \mathrm{light} / 8 \mathrm{~h}$ dark photoperiod at $22 / 18{ }^{\circ} \mathrm{C}$. Dark treatments were performed in the light period.

The pentuple mutant (ID: N16298) (Feng et al., 2008) was obtained from the Nottingham Arabidopsis Stock Centre (NASC). gal-3 (Sun et al., 1992; Wilson et al., 1992), gai 17 (Peng et al., 1997), 35S::PIP2-GFP (Cutler et al., 2000), 35S::PIN1 (Benkova et al., 2003), DR5rev::GFP (Friml et al., 2003), AUX1::AUX1-GFP (Swarup et al., 2004), PIN7::PIN7-GFP (Blilou et al., 2005), PIN2::PIN2-GFP (Tanaka et al., 2006), PGP19::PGP19-GFP (Mravec et al., 2008), snx1-1 x PIN2::PIN2-GFP (KleineVehn et al., 2008), TA::PIN2-GFP (Abas et al., 2006), SNX1::SNX1-GFP (Jallais et al., 2006) were described previously. Combinations of mutations and reporter lines were obtained by crossing individual lines.

\section{Pharmacological treatments and experimental conditions}

Chemicals were applied in solid or liquid Murashige and Skoog (MS) medium or by spraying 7 d-old seedlings with $\mathrm{AgNO}_{3}\left(20 \mathrm{mM}\right.$ stock in $\mathrm{H}_{2} \mathrm{O}$; f.c. $\left.20 \mu \mathrm{M}\right)$, BFA (50 $\mathrm{mM}$ stock in ethanol; f.c. $50 \mu \mathrm{M})$, DEX ( $30 \mathrm{mM}$ stock in DMSO; f.c. $30 \mu \mathrm{M})$, ( $\mathrm{GA}_{3}$ $(100 \mathrm{mM}$ stock in DMSO; f.c. $50 \mu \mathrm{M})$, uniconazole $(10 \mathrm{mM}$ stock in DMSO; f.c. $10 \mu \mathrm{M})$, paclobutrazole $(10 \mathrm{mM}$ stock in DMSO; f.c. $10 \mu \mathrm{M})$ or wortmannin $(10 \mathrm{mM}$ stock in DMSO; f.c. $30 \mu \mathrm{M})$. Mock treatments were done by spraying equal amounts of solvent (DMSO). Double treatments were performed within an $1 \mathrm{~h}$ interval.

Dark treatments were done as described previously (Kleine-Vehn et al. 2008). To compare protein concentrations in the lytic vacuole, epidermal cells at the interface of the meristematic and elongation zone were recorded. For live cell GFP imaging a Leica DM6000 CS, TCS SP5 AOBS confocal laser scanning microscope was used and fluorescent signals were quantified using the integrated Leica quantification module 
(LAS AF 2.1.0). Fluorescent measurements were done on the original Leica image files. All independent experiments were carried out at least in triplicates. Representative images are shown. Statistics were evaluated with GraphPad QuickCalcs t-test (http://graphpad.com/quickcalcs/index.cfm).

\section{Quantitative Analysis of Root Gravitropism}

5 d-old seedlings were grown vertically and $\mathrm{GA}_{3}$ (Duchefa) or uniconazole (Wako Pure Chemical Industries, Ltd) was applied for $3 \mathrm{~h}$ and $2 \mathrm{~d}$, respectively, before plates were turned through $135^{\circ}$ for additional $12 \mathrm{~h}$ gravity stimulation in the dark. All gravistimulated roots were assigned to one of the eight $45^{\circ}$ sectors on a gravitropism diagram. The length of bars in the diagram represents percentage of seedlings assigned to the respective sector. For time course experiments $7 \mathrm{~d}$ old seedlings were gravistimulated in the light by a $90^{\circ}$ rotation and the angle that root tips were deviating from the vertical plane were recorded after $2.5,4,6,8$ and $24 \mathrm{~h}$ using ImageJ software (NIH, USA).

\section{Immunodetection of gibberellic acid in roots and competition assay}

Whole-mount immunolocalization was done as described (Paciorek et al., 2006) after a pre-fixation step using a freshly prepared $3 \%$ N-Ethyl-N'-(3-dimethylaminopropyl) carbodiimide hydrochloride (EDAC) (Sigma) -solution in PBS for $1 \mathrm{~h}$ (Benkova et al., 2003). Antibodies were diluted as follows: 1:100 BSA (Agrisera), 1:200 DyLight 488 (Agrisera), 1:100 anti-GA 3 (Agrisera), and 1:150 for Atto647N conjugated anti-rat/goat (kindly provided by Stefan Jakobs, Max Planck Institute for Biophysical Chemistry, Göttingen). Antibody depletion experiments to identify GA specific signals were carried out with $\mathrm{GA}_{3}$-BSA conjugate obtained from Agrisera. Anti GA antibody and $\mathrm{GA}_{3}-\mathrm{BSA}$ conjugate were used in an 1:10 ratio. The setup for antibody depletion was designed with competition calculator from Agrisera. Antibody and $\mathrm{GA}_{3}-\mathrm{BSA}$ conjugate were incubated in $1 \mathrm{x}$ PBS $\left(24 \mathrm{~h}, 4^{\circ} \mathrm{C}\right.$, rotator) in a total volume of $225 \mu \mathrm{L}$ and then used as a primary antibody for immunodetection of GA in paraformaldehyde fixed and BSA blocked root samples. In parallel non-depleted serum was used to differentiate between GA specific and non-specific signals in the immunolocalization experiments. 


\section{Immunodetection of PIN proteins in roots}

Automated whole mount protein immunolocalization was done as described (Sauer et al. 2006). The anti-PIN1 rabbit antibody (Paciorek et al., 2005) was used at dilution $1: 500$.

\section{Membrane protein extraction and SDS-PAGE analysis}

$100 \mathrm{mg}$ of roots from seedlings (5-6 DAG) were homogenized and resuspended in extraction buffer (50 mM Tris at $\mathrm{pH} 6.8,25 \%(\mathrm{v} / \mathrm{v})$ D-Sorbitol, $1.5 \%(\mathrm{w} / \mathrm{v})$ insoluble poly vinylpolypyrrolidone, $10 \mathrm{mM} \mathrm{Na}$ EDTA, $10 \mathrm{mM}$ NaEGTA, $1 \mathrm{mM}$ 1,4dithioerythritol (DTE), $50 \mathrm{mM} \mathrm{NaF}, 10 \mathrm{mM}$ potassium phosphate buffer $\mathrm{pH} 7.8,40 \mathrm{mM}$ $\beta$-glycerophosphate, $0.2 \%(\mathrm{w} / \mathrm{v})$ casein and protease inhibitors: $1 \mathrm{mM}$ benzamidine, 1 $\mathrm{mM}$ PMSF, $3.5 \mu \mathrm{g} \mathrm{ml}^{-1}$ E64, $1 \mu \mathrm{g} \mathrm{ml}^{-1}$ pepstatin, $1 \mu \mathrm{g} \mathrm{m}{ }^{-1}$ leupeptin, $1 \mu \mathrm{g} \mathrm{ml} l^{-1}$ aprotinin and 1 Roche complete mini protease inhibitor tablet per $10 \mathrm{ml}$. Three steps of extraction were followed by centrifugation in a standard benchtop centrifuge $(2100 \mathrm{rpm}$ for $2 \mathrm{~min}, 4^{\circ} \mathrm{C}$ ). Collected supernatant was combined, mixed by vortexing and centrifuged $\left(14,000 \mathrm{rpm}\right.$ for $\left.90 \mathrm{~min}, 4{ }^{\circ} \mathrm{C}\right)$. Pellets were resuspended in $50 \mathrm{mM}$ Tris at $\mathrm{pH}$ 7.5, $20 \%$ glycerol, 2 mM EGTA, 2 mM EDTA, 50-500 $\mu \mathrm{M}$ DTE, and protease inhibitors as above. Equal amounts of protein were separated by $10 \%$ SDS-Urea PAGE, probed with affinity-purified anti-PIN2 (1:20; Abas et al 2006), followed by HRP-conjugated donkey anti-rabbit IgG (1:10,000; ECLtm Western Blotting Detection Reagents from GE Healthcare).

\section{RT-PCR}

RNA extraction of $50 \mathrm{mg}$ root material was performed according to the manufactures manual (innuPREP Plant RNA-Kit; Analytik Jena). DNA digestion was done using the turboDNA-free-Kit from Ambion (Applied Biosystems). cDNA synthesis was performed with 1,5 $\mu \mathrm{g}$ of total RNA, 20 pmol of oligo(dT) $(18 \mathrm{dT})$ oligonucleotides as described in the manual of the RevertAid ${ }^{\mathrm{TM}} \mathrm{H}$ Minus First Strand cDNASynthesis-Kit (Fermentas).

The iCycler system (Bio-Rad) was used for amplification and quantification of cDNA using QuantiTect primers from Qiagen for PIN2 (QT00843850), PIN7 (QT00864122) and as reference UBQ5 (UBQ5sense 5'-GACGCTTCATCTCGTCC-3' and UBQ5antisense 5 '-GTAAACGTAGGTGAGTCCA-3' (Zander et al., 2010; Kesarwani 
et al., 2007). To monitor pharmacological treatments, we determined GA20oxl expression using gene specific GA20oxl primers (GA20sense 5'CCGTAACTGTAGAAGACT-'3 and GA20antisense 5

TACTCTTGATACACCTTCCT-'3). AtGH3.1 cDNA was amplified using the primers GH3.1sense 5'-AACTTATGCCGACCATTAAAGAA-'3 and GH3.1antisense 5'TCTAGACCCGGCACATACAA -'3. The amplification mix consisted of $1 \times \mathrm{NH}_{4}$ reaction buffer (Bioline), $2 \mathrm{mM} \mathrm{MgCl} 2,100 \mu \mathrm{M}$ dNTPs, $0.4 \mu \mathrm{M}$ of primers, 0.25 units of BIOTaq DNA polymerase (Bioline), $10 \mathrm{nM}$ fluorescein (Bio-Rad), 1:100000 diluted SYBR Green I solution (Cambrex), $1 \mu \mathrm{L}$ of a 1:10 dilution of cDNA as template, and double distilled water to a total volume of $25 \mu \mathrm{L}$. The PCR regime consisted of an initial $90 \mathrm{~s}$ denaturation step at $95^{\circ} \mathrm{C}$ followed by 40 cycles of $20 \mathrm{~s}$ at $95{ }^{\circ} \mathrm{C}, 20 \mathrm{~s}$ at $55^{\circ} \mathrm{C}$, and $40 \mathrm{~s}$ at $72^{\circ} \mathrm{C}$. Calculations were done according to the $2^{-\Delta \Delta \mathrm{CT}}$ method (Livak and Schmittgen, 2001).

\section{DEX depletion assay}

TA::PIN2-GFP seedlings were grown on solid $1 / 2 \mathrm{MS}$ for $6 \mathrm{~d}$ and transferred to $30 \mu \mathrm{M}$ DEX supplemented solid $1 / 2$ MS media for $24 \mathrm{~h}$. After washing $3 \times 20 \mathrm{~min}$ in liquid $1 / 2$ MS without sucrose the roots were mounted in $3 \%$ glycerine with $50 \mu \mathrm{M} \mathrm{GA}_{3}$ or equal amount of GA solvent and PIN2-GFP signal was recorded after 2, 4, 6, 7 and $24 \mathrm{~h}$.

\section{Accession Numbers}

Sequence information of genes described in this article is filed in the Arabidopsis Genome Initiative database under the following accession numbers: $A U X 1$, AT2G38120; GA1, AT4G02780; GAI, AT1G14920; GH3.1, AT2G14960; PGP19, AT3G28860; PIN1, AT1G73590; PIN2, AT5G57090; PIN3, AT1G70940; PIN4, AT2G01420; PIN7, AT1G23080; PIP2, AT3G53420; RGA, AT2G01570; RGL1, AT1G66350; $R G L 2$, AT3G03450; RGL3, AT5G17490; SNX1, AT5G06140.

\section{Acknowledgements}

We thank Eva Benkova, Jürgen Kleine-Vehn and René Fuchs for valuable comments and suggestions. We thank Volker Lipka for providing the infrastructure of his department and helpful criticism. We acknowledge Alexandra Matei's contribution to the project. We are grateful for funding by the DFG (ERA-PD 045).

\section{References}

Abas, L., Benjamins, R., Malenica, N., Paciorek, T., Wirniewska, J., MoulinierAnzola, J.C., Sieberer, T., Friml, J., and Luschnig, C. (2006). Intracellular trafficking and proteolysis of the Arabidopsis auxin-efflux facilitator PIN2 are involved in root gravitropism. Nature Cell Biology 8, 249-256. 
Baiges, I., Schaffner, A.R., Affenzeller, M.J., and Mas, A. (2002). Plant aquaporins. Physiol. Plant. 115, 175-182.

Benkova, E., Michniewicz, M., Sauer, M., Teichmann, T., Seifertova, D., Jürgens, G., and Friml, J. (2003). Local, efflux-dependent auxin gradients as a common module for plant organ formation. Cell 115, 591-602.

Bennett, M.J., Marchant, A., Green, H.G., May, S.T., Ward, S.P., Millner, P.A., Walker, A.R., Schulz, B., and Feldmann, K.A. (1996). Arabidopsis AUX1 gene: A permease-like regulator of root gravitropism. Science 273, 948-950.

Blakeslee, J.J., Bandyopadhyay, A., Lee, O.R., Mravec, J., Titapiwatanakun, B., Sauer, M., Makam, S.N., Cheng, Y., Bouchard, R., Adamec, J., Geisler, M., Nagashima, A., Sakai, T., Martinoia, E., Friml, J., Peer, W.A., and Murphy, A.S. (2007). Interactions among PIN-FORMED and P-glycoprotein auxin transporters in Arabidopsis. Plant Cell 19, 131-147.

Blilou, I., Xu, J., Wildwater, M., Willemsen, V., Paponov, I., Friml, J., Heidstra, R., Aida, M., Palme, K., and Scheres, B. (2005). The PIN auxin efflux facilitator network controls growth and patterning in Arabidopsis roots. Nature 433, 39-44.

Chen, R.J., Hilson, P., Sedbrook, J., Rosen, E., Caspar, T., and Masson, P.H. (1998). The Arabidopsis thaliana AGRAVITROPIC 1 gene encodes a component of the polar-auxin-transport efflux carrier. Proceedings of the National Academy of Sciences of the United States of America 95, 1511215117.

Cui, D.Y., Neill, S.J., Tang, Z.C., and Cai, W.M. (2005). Gibberellin-regulated XET is differentially induced by auxin in rice leaf sheath bases during gravitropic bending. J. Exp. Bot. 56, 1327-1334.

Cutler, S.R., Ehrhardt, D.W., Griffitts, J.S., and Somerville, C.R. (2000). Random GFP :: cDNA fusions enable visualization of subcellular structures in cells of Arabidopsis at a high frequency. Proceedings of the National Academy of Sciences of the United States of America 97, 3718-3723.

Dhonukshe, P., Aniento, F., Hwang, I., Robinson, D.G., Mravec, J., Stierhof, Y.D., and Friml, J. (2007). Clathrin-mediated constitutive endocytosis of PIN auxin efflux carriers in Arabidopsis. Curr. Biol. 17, 520-527.

Feng, S.H., Martinez, C., Gusmaroli, G., Wang, Y., Zhou, J.L., Wang, F., Chen, L.Y., Yu, L., Iglesias-Pedraz, J.M., Kircher, S., Schafer, E., Fu, X.D., Fan, L.M., and Deng, X.W. (2008). Coordinated regulation of Arabidopsis thaliana development by light and gibberellins. Nature 451, 475-U479.

Frigerio, M., Alabadi, D., Perez-Gomez, J., Garcia-Carcel, L., Phillips, A.L., Hedden, P., and Blazquez, M.A. (2006). Transcriptional regulation of gibberellin metabolism genes by auxin signaling in arabidopsis. Plant Physiology 142, 553-563.

Friml, J. (2010). Subcellular trafficking of PIN auxin efflux carriers in auxin transport. Eur. J. Cell Biol. 89, 231-235.

Friml, J., Benková, E., Mayer, U., Palme, K. and Muster, G. (2003) Automated whole mount localisation techniques for plant seedlings. Plant J. 34, 115-124.

Friml, J., Vieten, A., Sauer, M., Weijers, D., Schwarz, H., Hamann, T., Offringa, R., and Jürgens, G. (2003). Efflux-dependent auxin gradients establish the apical-basal axis of Arabidopsis. Nature 426, 147-153.

Friml, J., Wisniewska, J., Benkova, E., Mendgen, K., and Palme, K. (2002). Lateral relocation of auxin efflux regulator PIN3 mediates tropism in Arabidopsis. Nature 415, 806-809.

Friml, J., Yang, X., Michniewicz, M., Weijers, D., Quint, A., Tietz, O., Benjamins, R., Ouwerkerk, P.B.F., Ljung, K., Sandberg, G., Hooykaas, P.J.J., Palme, 
K., and Offringa, R. (2004). A PINOID-dependent binary switch in apicalbasal PIN polar targeting directs auxin efflux. Science 306, 862-865.

Fu, X.D., and Harberd, N.P. (2003). Auxin promotes Arabidopsis root growth by modulating gibberellin response. Nature 421, 740-743.

Gälweiler, L., Guan, C.H., Müller, A., Wisman, E., Mendgen, K., Yephremov, A., and Palme, K. (1998). Regulation of polar auxin transport by AtPIN1 in Arabidopsis vascular tissue. Science 282, 2226-2230.

Geisler, M., Blakeslee, J.J., Bouchard, R., Lee, O.R., Vincenzetti, V., Bandyopadhyay, A., Titapiwatanakun, B., Peer, W.A., Bailly, A., Richards, E.L., Ejenda, K.F.K., Smith, A.P., Baroux, C., Grossniklaus, U., Muller, A., Hrycyna, C.A., Dudler, R., Murphy, A.S., and Martinoia, E. (2005). Cellular efflux of auxin catalyzed by the Arabidopsis MDR/PGP transporter AtPGP1. Plant Journal 44, 179-194.

Geldner, N., Friml, J., Stierhof, Y.D., Jürgens, G., and Palme, K. (2001). Auxin transport inhibitors block PIN1 cycling and vesicle traficking. Nature 413, 425428.

Harrison, B.R., and Masson, P.H. (2008). ARL2, ARG1 and PIN3 define a gravity signal transduction pathway in root statocytes. Plant Journal 53, 380-392.

Hartweck, L.M. (2008). Gibberellin signaling. Planta 229, 1-13.

Hasenstein, K.H., and Evans, M.L. (1988). Effects of cations on hormone transport in primary roots of Zea mays. Plant Physiology 86, 890-894.

Jaillais, Y., Fobis-Loisy, I., Miege, C., Rollin, C., and Gaude, T. (2006). AtSNX1 defines an endosome for auxin-carrier trafficking in Arabidopsis. Nature 443, 106-109.

Jaillais, Y., Santambrogio, M., Rozier, F., Fobis-Loisy, I., Miege, C., and Gaude, T. (2007). The retromer protein VPS29 links cell polarity and organ initiation in plants. Cell 130, 1057-1070.

Jürgens, G., and Geldner, N. (2007). The high road and the low road: Trafficking choices in plants. Cell 130, 977-979.

Kesarwani, M., Yoo, J.M., and Dong, X.N. (2007). Genetic interactions of TGA transcription factors in the regulation of pathogenesis-related genes and disease resistance in Arabidopsis. Plant Physiology 144, 336-346.

Kleine-Vehn, J., and Friml, J. (2008). Polar Targeting and Endocytic Recycling in Auxin-Dependent Plant Development. Annual Review of Cell and Developmental Biology 24, 447-473.

Kleine-Vehn, J., Leitner, J., Zwiewka, M., Sauer, M., Abas, L., Luschnig, C., and Friml, J. (2008). Differential degradation of PIN2 auxin efflux carrier by retromer-dependent vacuolar targeting. Proceedings of the National Academy of Sciences of the United States of America 105, 17812-17817.

Livak, K.J., and Schmittgen, T.D. (2001). Analysis of relative gene expression data using real-time quantitative PCR and the 2(T)(-Delta Delta C) method. Methods 25, 402-408.

Long, J.C., Zhao, W., Rashotte, A.M., Muday, G.K., and Huber, S.C. (2002). Gravity-stimulated changes in auxin and invertase gene expression in maize pulvinal cells. Plant Physiology 128, 591-602.

Luschnig, C., Gaxiola, R.A., Grisafi, P., and Fink, G.R. (1998). EIR1, a root-specific protein involved in auxin transport, is required for gravitropism in Arabidopsis thaliana. Genes Dev. 12, 2175-2187.

Mravec, J., Kubes, M., Bielach, A., Gaykova, V., Petrasek, J., Skupa, P., Chand, S., Benkova, E., Zazimalova, E., and Friml, J. (2008). Interaction of PIN and 
PGP transport mechanisms in auxin distribution-dependent development. Development 135, 3345-3354.

Muday, G.K. (2001). Auxins and tropisms. Journal of Plant Growth Regulation 20, 226-243.

Müller, A., Guan, C.H., Gälweiler, L., Tanzler, P., Huijser, P., Marchant, A., Parry, G., Bennett, M., Wisman, E., and Palme, K. (1998). AtPIN2 defines a locus of Arabidopsis for root gravitropism control. Embo J. 17, 6903-6911.

Nemhauser, J.L., Hong, F.X., and Chory, J. (2006). Different plant hormones regulate similar processes through largely nonoverlapping transcriptional responses. Cell 126, 467-475.

Noh, B., Murphy, A.S., and Spalding, E.P. (2001). Multidrug resistance-like genes of Arabidopsis required for auxin transport and auxin-mediated development. Plant Cell 13, 2441-2454.

Oliviusson, P., Heinzerling, O., Hillmer, S., Hinz, G., Tse, Y.C., Jiang, L.W., and Robinson, D.G. (2006). Plant retromer, localized to the prevacuolar compartment and microvesicles in Arabidopsis, may interact with vacuolar sorting receptors. Plant Cell 18, 1239-1252.

Ottenschläger, I., Wolff, P., Wolverton, C., Bhalerao, R.P., Sandberg, G., Ishikawa, H., Evans, M., and Palme, K. (2003). Gravity-regulated differential auxin transport from columella to lateral root cap cells. Proceedings of the National Academy of Sciences of the United States of America 100, 2987-2991.

Paciorek, T., Sauer, M., Balla, J., Wisniewska, J., and Friml, J. (2006). Immunocytochemical technique for protein localization in sections of plant tissues. Nat. Protoc. 1, 104-107.

Peng, J.R., Carol, P., Richards, D.E., King, K.E., Cowling, R.J., Murphy, G.P., and Harberd, N.P. (1997). The Arabidopsis GAI gene defines a signaling pathway that negatively regulates gibberellin responses. Genes Dev. 11, 3194-3205.

Perera, I.Y., Heilmann, I., and Boss, W.F. (1999). Transient and sustained increases in inositol 1,4,5-hisphosphate precede the differential growth response in gravistimulated maize pulvini. Proceedings of the National Academy of Sciences of the United States of America 96, 5838-5843.

Petrasek, J., Mravec, J., Bouchard, R., Blakeslee, J.J., Abas, M., Seifertova, D., Wisniewska, J., Tadele, Z., Kubes, M., Covanova, M., Dhonukshe, P., Skupa, P., Benkova, E., Perry, L., Krecek, P., Lee, O.R., Fink, G.R., Geisler, M., Murphy, A.S., Luschnig, C., Zazimalova, E., and Friml, J. (2006). PIN proteins perform a rate-limiting function in cellular auxin efflux. Science 312, 914-918.

Phinney, B., O. (1983). The history of gibberellins. (New York: Praeger Publishers ).

Ruzicka, K., Ljung, K., Vanneste, S., Podhorska, R., Beeckman, T., Friml, J., and Benkova, E. (2007). Ethylene regulates root growth through effects on auxin biosynthesis and transport-dependent auxin distribution. Plant Cell 19, 21972212.

Sauer, M., Paciorek, T., Benkova, E., and Friml, J. (2006). Immunocytochemical techniques for whole-mount in situ protein localization in plants. Nat. Protoc. 1, 98-103.

Sun, T.P., and Kamiya, Y. (1994). The Arabidopsis GA1 locus encodes the cyclase ent-kaurene synthetase-A of gibberellin biosynthesis. Plant Cell 6, 1509-1518.

Sun, T.P., Goodman, H.M., and Ausubel, F.M. (1992). Cloning the Arabidopsis GA1 locus by genomic substraction. Plant Cell 4, 119-128.

Swarup, K., Benkova, E., Swarup, R., Casimiro, I., Peret, B., Yang, Y., Parry, G., Nielsen, E., De Smet, I., Vanneste, S., Levesque, M.P., Carrier, D., James, 
N., Calvo, V., Ljung, K., Kramer, E., Roberts, R., Graham, N., Marillonnet, S., Patel, K., Jones, J.D.G., Taylor, C.G., Schachtman, D.P., May, S., Sandberg, G., Benfey, P., Friml, J., Kerr, I., Beeckman, T., Laplaze, L., and Bennett, M.J. (2008). The auxin influx carrier LAX3 promotes lateral root emergence. Nature Cell Biology 10, 946-954.

Swarup, R., Kargul, J., Marchant, A., Zadik, D., Rahman, A., Mills, R., Yemm, A., May, S., Williams, L., Millner, P., Tsurumi, S., Moore, I., Napier, R., Kerr, I.D., and Bennett, M.J. (2004). Structure-function analysis of the presumptive Arabidopsis auxin permease AUX1. Plant Cell 16, 3069-3083.

Tamura, K., Shimada, T., Ono, E., Tanaka, Y., Nagatani, A., Higashi, S., Watanabe, M., Nishimura, M., and Hara-Nishimura, I. (2003). Why green fluorescent fusion proteins have not been observed in the vacuoles of higher plants. Plant Journal 35, 545-555.

Tanaka, H., Dhonukshe, P., Brewer, P.B., and Friml, J. (2006). Spatiotemporal asymmetric auxin distribution: a means to coordinate plant development. Cellular and Molecular Life Sciences 63, 2738-2754.

Tanimoto, E. (2005). Regulation of root growth by plant hormones - Roles for auxin and gibberellin. Critical Reviews in Plant Sciences 24, 249-265.

Ulmasov, T., Murfett, J., Hagen, G., and Guilfoyle, T.J. (1997). Aux/IAA proteins repress expression of reporter genes containing natural and highly active synthetic auxin response elements. Plant Cell 9, 1963-1971.

Utsuno, K., Shikanai, T., Yamada, Y., and Hashimoto, T. (1998). AGR, an Agravitropic locus of Arabidopsis thaliana, encodes a novel membrane-protein family member. Plant and Cell Physiology 39, 1111-1118.

Went, F.W. (1926). On Growth accelerating Substances in the Coleoptile of Avena sativa. Proceedings of the Koninklijke Nederlandse Akademie van Wetenschappen 30, 10-19.

Wilson, R.N., Heckman, J.W., and Somerville, C.R. (1992). Gibberellin is required for flowering in Arabidopsis thaliana under short days. Plant Physiology 100, 403-408.

Wisniewska, J., Xu, J., Seifertova, D., Brewer, P.B., Ruzicka, K., Blilou, I., Rouquie, D., Scheres, B., and Friml, J. (2006). Polar PIN localization directs auxin flow in plants. Science 312, 883-883.

Wolbang, C.M., Davies, N.W., Taylor, S.A., and Ross, J.J. (2007). Gravistimulation leads to asymmetry of both auxin and gibberellin levels in barley pulvini. Physiol. Plant. 131, 140-148.

Zander, M., La Camera, S., Lamotte, O., Metraux, J.P., and Gatz, C. (2010) Arabidopsis thaliana class-II TGA transcription factors are essential activators of jasmonic acid/ethylene-induced defense responses. Plant Journal 61, 200-210. 


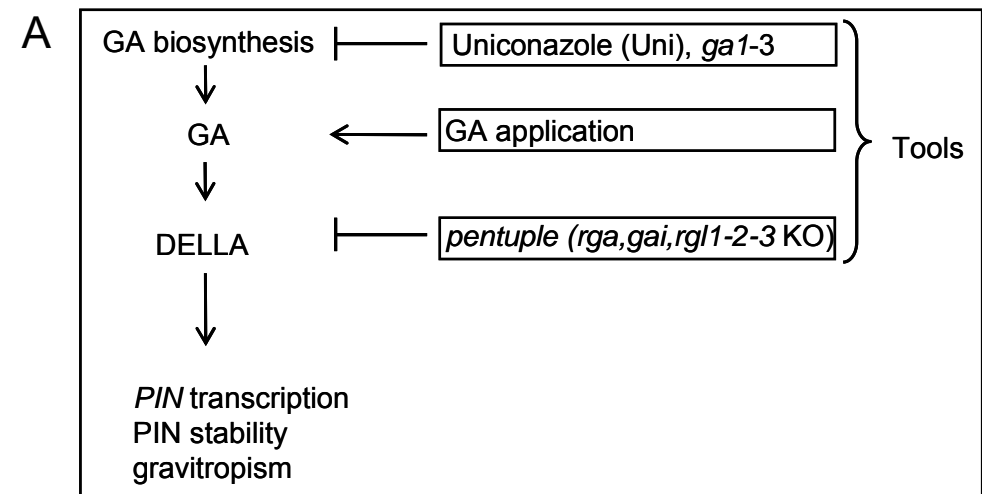

B

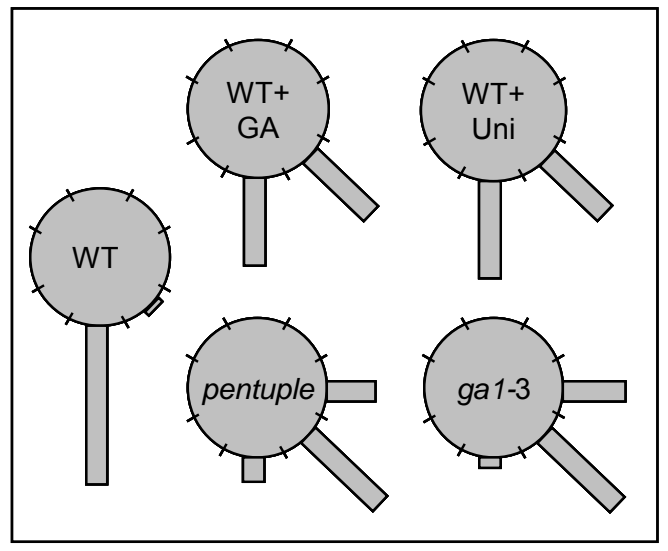

C

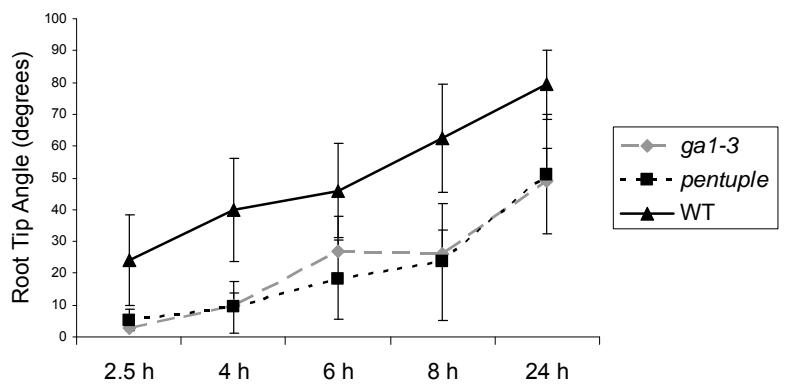

Figure 1. Scheme of experimental design to study impact of altered GA levels and signaling on root gravitropism.

(A) Pharmacological treatments and analysis of GA biosynthesis and signaling mutants have been used to study GA effects on PIN2 transcription, PIN2 stability and gravitropism. uniconazole (Uni): GA biosynthesis inhibitor; ga1-3: GA biosynthesis mutant; pentuple: pentuple mutant of all five Arabidopsis DELLA genes (B) Gravi-stimulated roots were assigned to one of the eight $45^{\circ}$ sectors on a gravitropism diagram. The length of bars in the diagram represents percentage of seedlings assigned to the respective sector. (C) Time course of root re-orientation after gravistimulation. WT: wildtype plants without treatment, WT + GA: wildtype plants pretreated for $3 \mathrm{~h}$ with $50 \mu \mathrm{M} \mathrm{GA}$, WT + Uni: wildtype plants pretreated for $2 \mathrm{~d}$ with $10 \mu \mathrm{M}$ uniconazole; gal-3: GA biosynthesis mutant; pentuple: pentuple mutant of all five DELLA genes, WT: wildtype plants without treatment, $(n=8$ seedlings per treatment, experiments were repeated three times). 

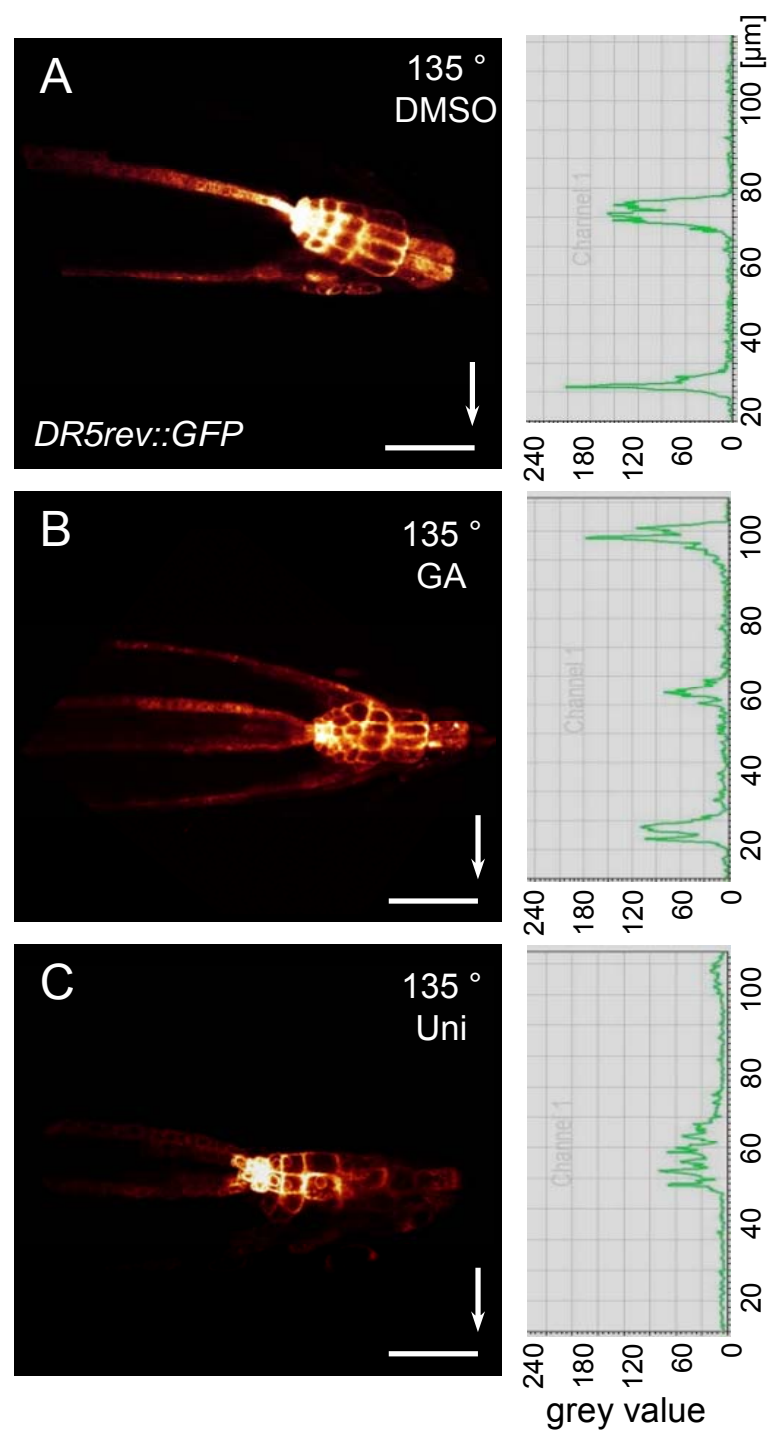

Figure 2. Altered GA levels affect the auxin-response marker DR5rev::GFP in gravitropically induced roots.

Arabidopsis DR5rev::GFP seedlings were pre-treated with (A) DMSO (GA and uniconazole solvent); (B) $50 \mu \mathrm{M}$ GA for $3 \mathrm{~h}$; (C) with $10 \mu \mathrm{M}$ uniconazole for $2 \mathrm{~d}$, and subsequently gravitropically induced for 1.5 h. Graphs in A, B, C show fluorescence profile of the root tip; arrows indicate direction of the gravity vector. Scale bar: $50 \mu \mathrm{m}$. 

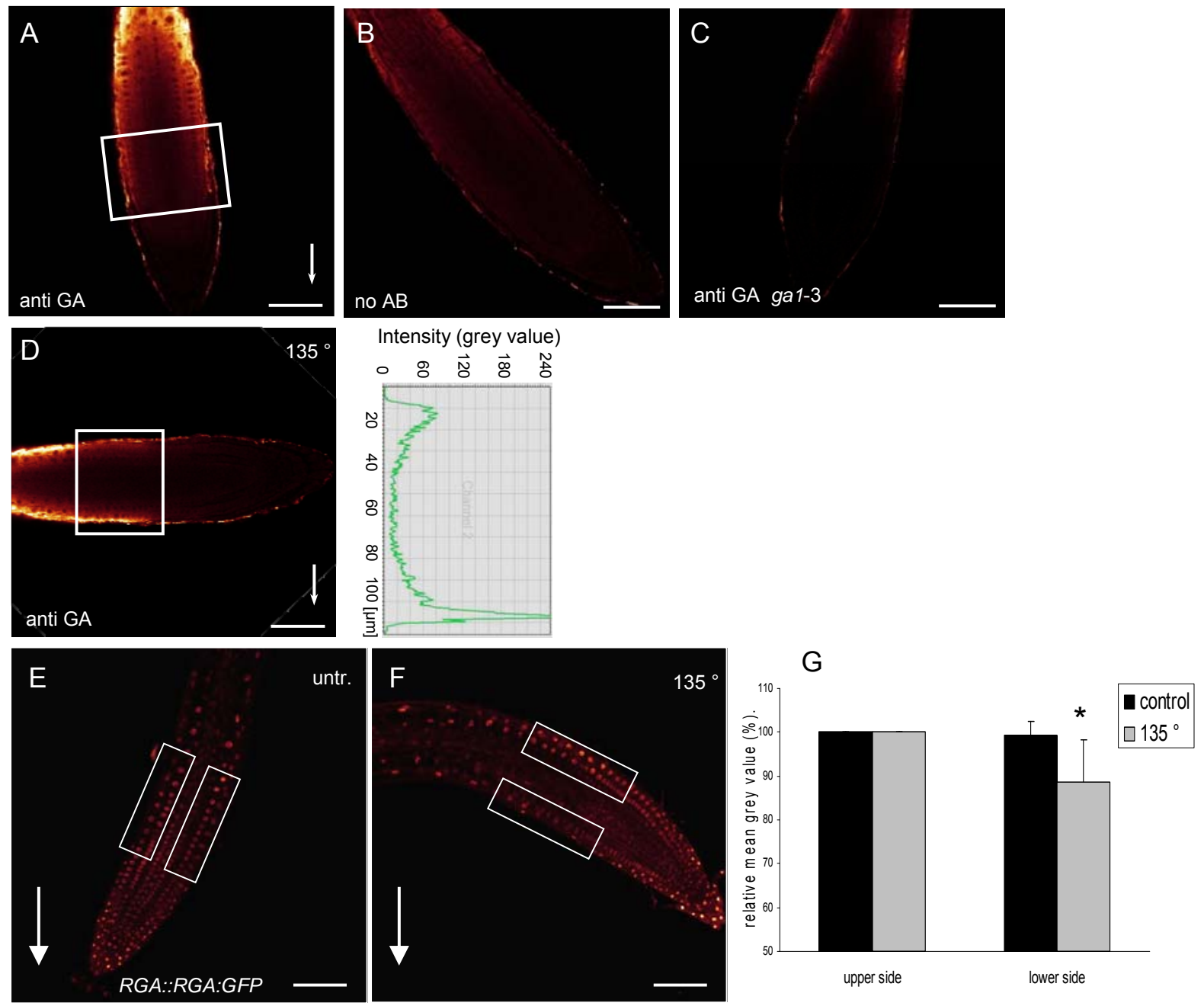

Figure 3. Detection of asymmetric GA localisation in gravitropically induced roots by immuno staining and analysis of the GA-response marker RGA-GFP.

Seedlings were grown vertically or gravitropically induced for $3 \mathrm{~h}$ and immuno staining was performed with a GA specific antibody. (A) vertically grown root; (B) vertically grown root, primary antibody omitted as control; (C) gal-3 mutant; (D) root gravitropically induced for $3 \mathrm{~h}$; arrows indicate direction of the gravity vector; graph shows fluorescence profile of the indicated area in D; (E) Arabidopsis $R G A:: R G A-G F P$ line grown vertically; (F) Arabidopsis $R G A:: R G A-G F P$ line gravitropically induced for $3 \mathrm{~h}$, boxes indicate areas used for quantification of fluorescence signal intensities, (G) quantification of $R G A:: R G A-G F P$ signal on upper and lower sides of control and gravistimulated roots by image analysis. Scale bars A-D: $50 \mu \mathrm{m}$; E,F: $100 \mu \mathrm{m}$. 

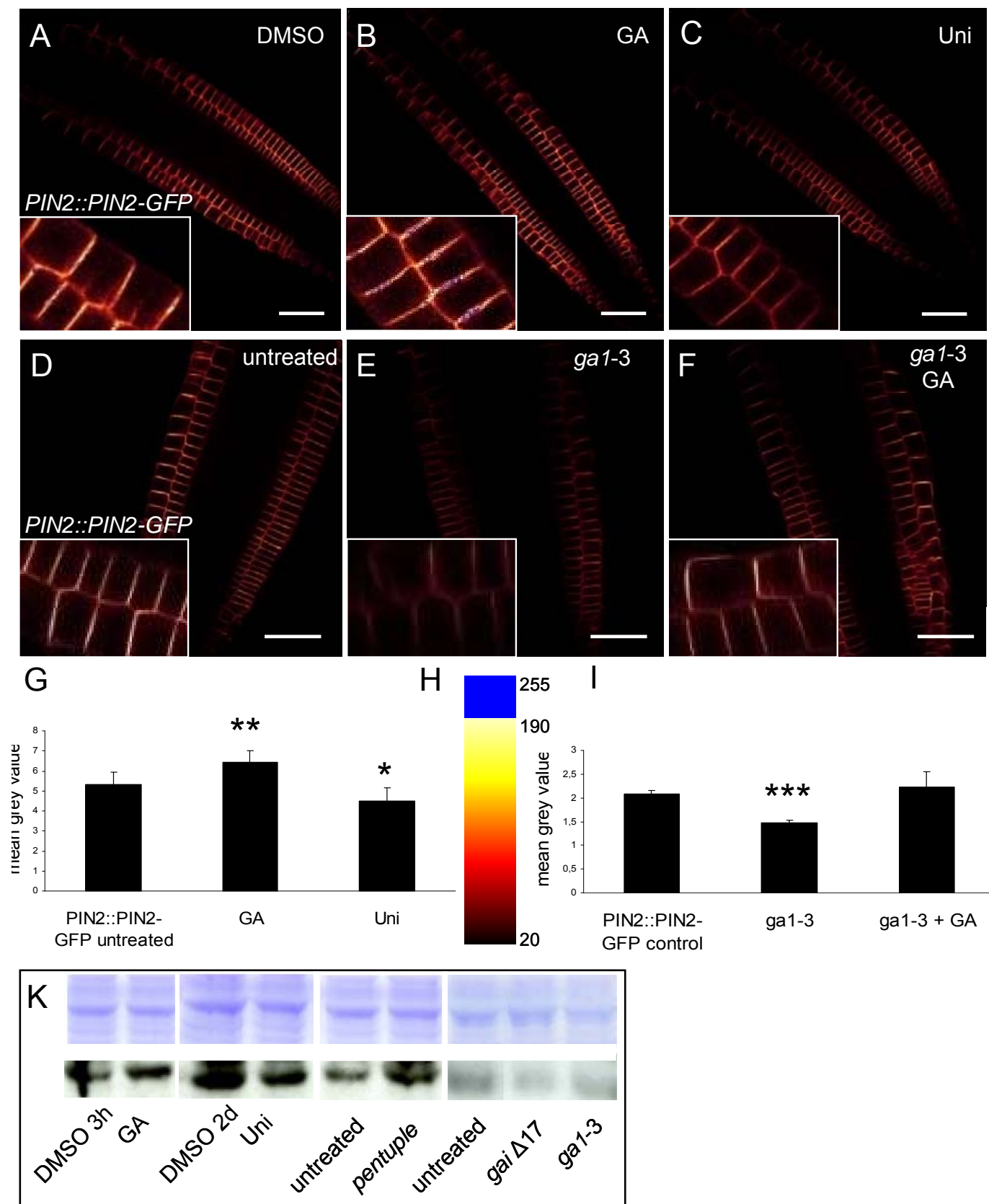

Figure 4. Effect of altered GA levels on plasma membrane localized PIN2 amounts.

Arabidopsis PIN2::PIN2-GFP seedlings were treated with (A) DMSO; (B) $50 \mu \mathrm{M}$ GA for 3 h; (C) $10 \mu \mathrm{M}$ uniconazole for $2 \mathrm{~d}$; (D) PIN2::PIN2-GFP seedling, untreated control; (E) PIN2::PIN2-GFP x gal-3; (F) $P I N 2:: P I N 2-G F P \times$ gal-3 treated for $3 \mathrm{~h}$ with $50 \mu \mathrm{M}$ GA; Scale bar: $50 \mu \mathrm{m}$; (G) quantification of $P I N 2: \because P I N 2-G F P$ expression by image analysis in seedlings treated as described in $\mathrm{A}, \mathrm{B}, \mathrm{C} ; \mathbf{( H )}$ color code of fluorescence signal intensities shown in A, B, C; (I) quantification of PIN2::PIN2-GFP expression by image analysis in seedlings treated as described in D, E, F; (K) Western Blot of plasma membrane proteins from roots; treatments and mutant lines from left to right: $3 \mathrm{~h}$ DMSO (GA control), 3 h $50 \mu \mathrm{M}$ GA, 2 d DMSO (uniconazole control), 2 d $10 \mu \mathrm{M}$ uniconazole, untreated wildtype (pentuple

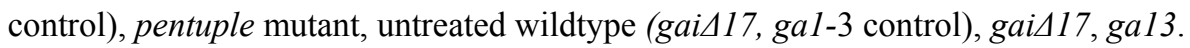


Time after DEX depletion

$2 \mathrm{~h}$

$4 \mathrm{~h}$

$6 \mathrm{~h}$

$7 \mathrm{~h}$ $25 \mathrm{~h}$
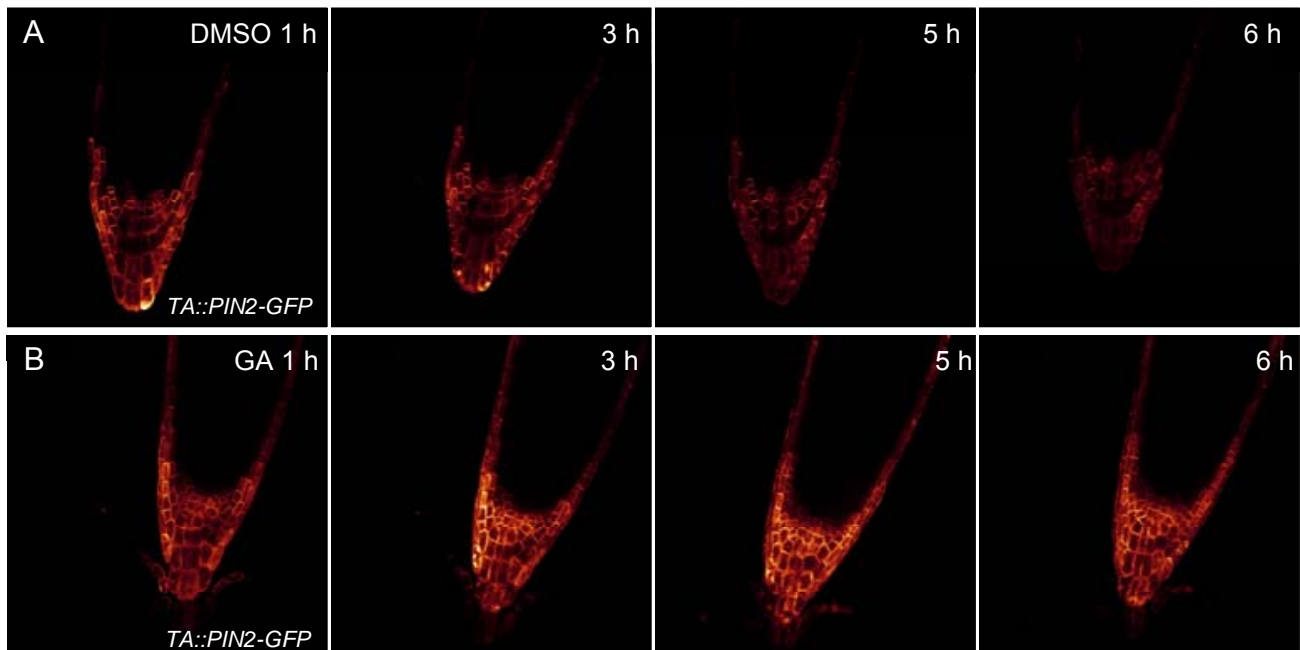

$5 \mathrm{~h}$

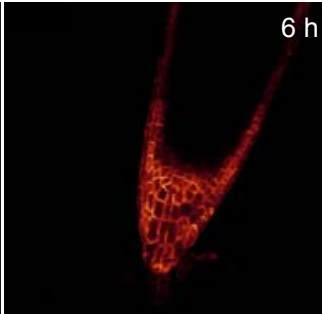

TA::PIN2-GFP

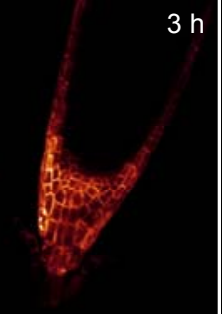

Figure 5. GA decreases degradation rate of de novo synthesized PIN2 protein.

PIN2 expression was induced in TA::PIN2-GFP seedlings by treatment with $30 \mu \mathrm{M}$ DEX for $24 \mathrm{~h}$. After depletion of DEX by washing, roots were mounted in $3 \%$ glycerine with or without $\mathrm{GA}_{3}$ and PIN2-GFP signal intensities were recorded after the indicated time points. (A) Control roots treated with DMSO (B) Roots treated with $50 \mu \mathrm{M} \mathrm{GA}_{3}$. (C) Control without DEX and $24 \mathrm{~h} \mathrm{GA}$ treatment.
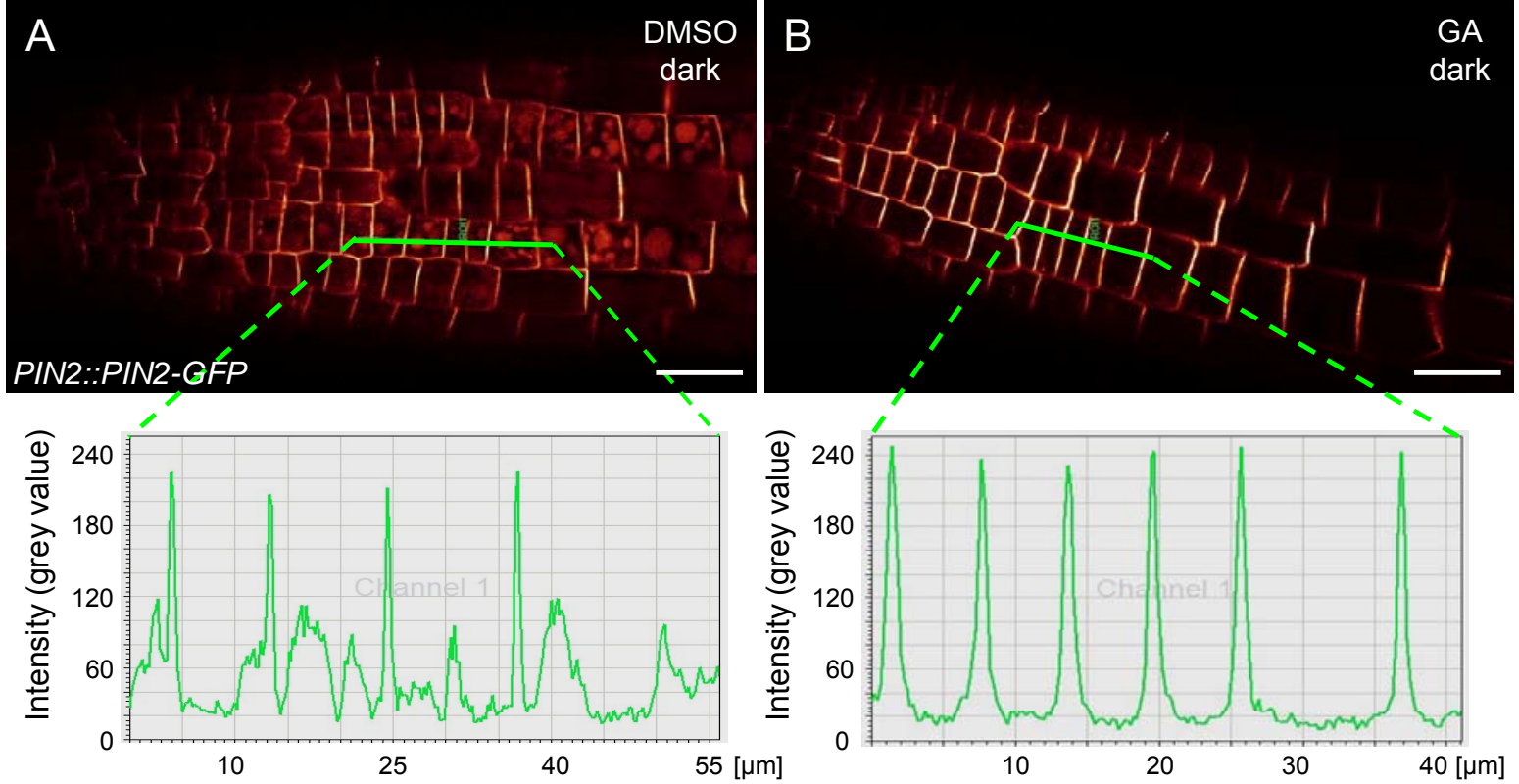

Figure 6. Altered GA levels impair PIN2 targeting to the lytic vacuole.

After treatment in the light seedlings were transferred to the dark for 6 h. PIN2::PIN2-GFP seedlings were pre-treated with (A) DMSO (GA solvent); (B) $50 \mu \mathrm{M}$ GA for $3 \mathrm{~h}$; graphs show fluorescence profile across indicated section. Scale bar: $25 \mu \mathrm{m}$. 

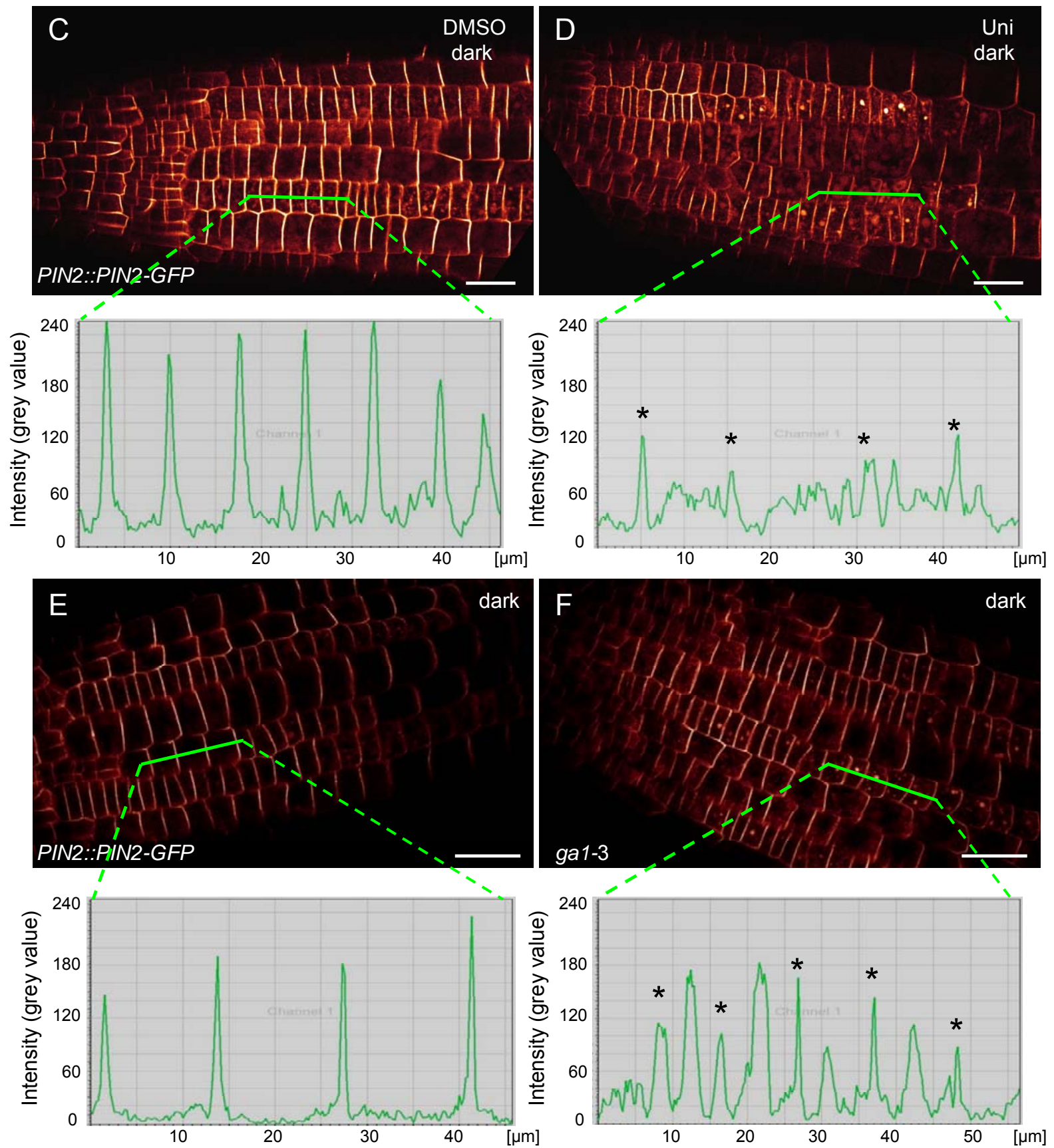

Figure 7. Altered GA levels impair PIN2 targeting to the lytic vacuole.

After treatment in the light seedlings were transferred to the dark for $6 \mathrm{~h}$. PIN2::PIN2-GFP seedlings were pre-treated with (A) DMSO (uniconazole solvent); (B) $10 \mu \mathrm{M}$ uniconazole for $2 \mathrm{~d}$; (C) PIN2::PIN2-GFP signal after $3 \mathrm{~h}$ dark in untreated roots; (D) PIN2::PIN2-GFP signal in gal-3 seedlings after $3 \mathrm{~h}$ dark; graphs show fluorescence profile across indicated section. Star indicates the border between two cells and the corresponding membrane signal. Scale bar: $25 \mu \mathrm{m}$. 

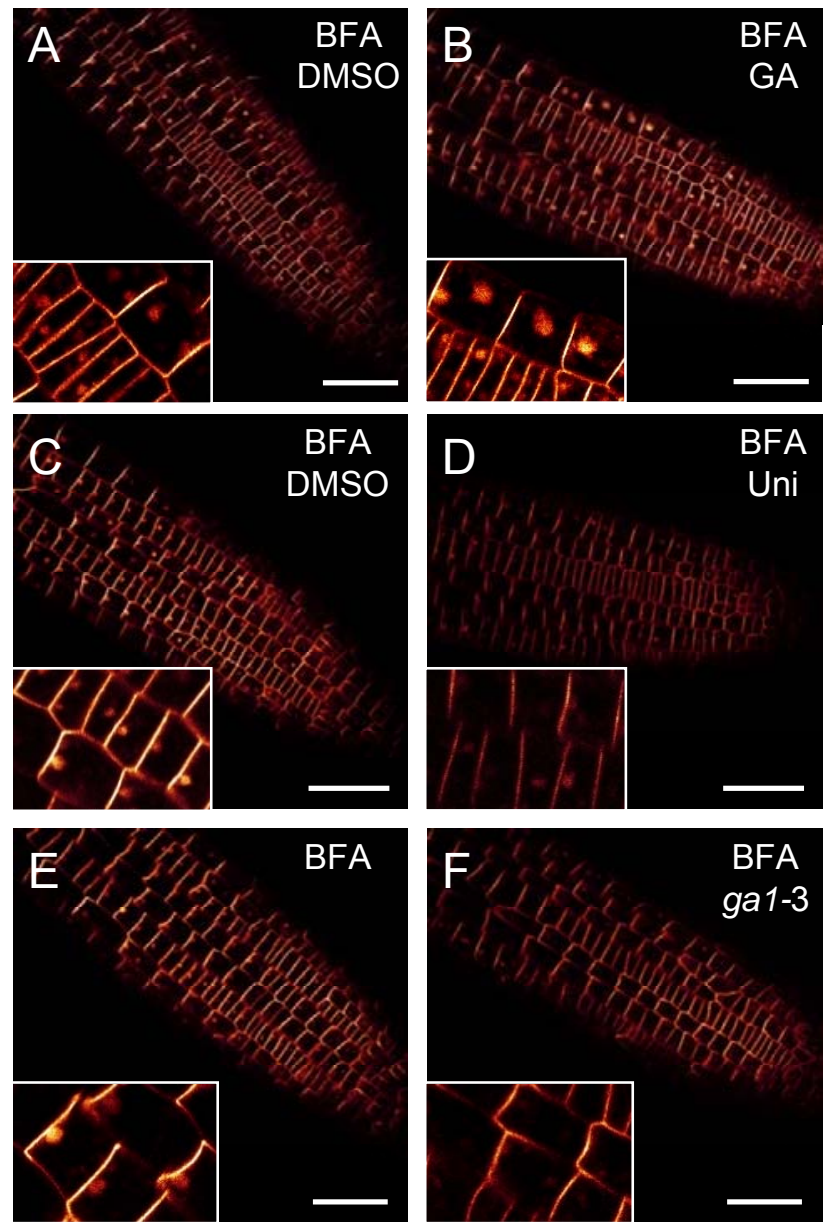

Figure 8. Response of PIN2-GFP trafficking to altered GA levels.

PIN2::PIN2-GFP signal in BFA endosomes after treatment with (A) DMSO for $3 \mathrm{~h}$ (GA control); (B) $50 \mu \mathrm{M}$ GA for $3 \mathrm{~h}$; (C) DMSO for $2 \mathrm{~d}$ (uniconazole control); (D) $10 \mu \mathrm{M}$ uniconazole for $2 \mathrm{~d}$; (E,F) PIN2-GFP signal in BFA endosomes of (E) PIN2::PIN2-GFP and (F) PIN2::PIN2-GFP x gal-3 seedlings. Scale bar: $50 \mu \mathrm{m}$. 

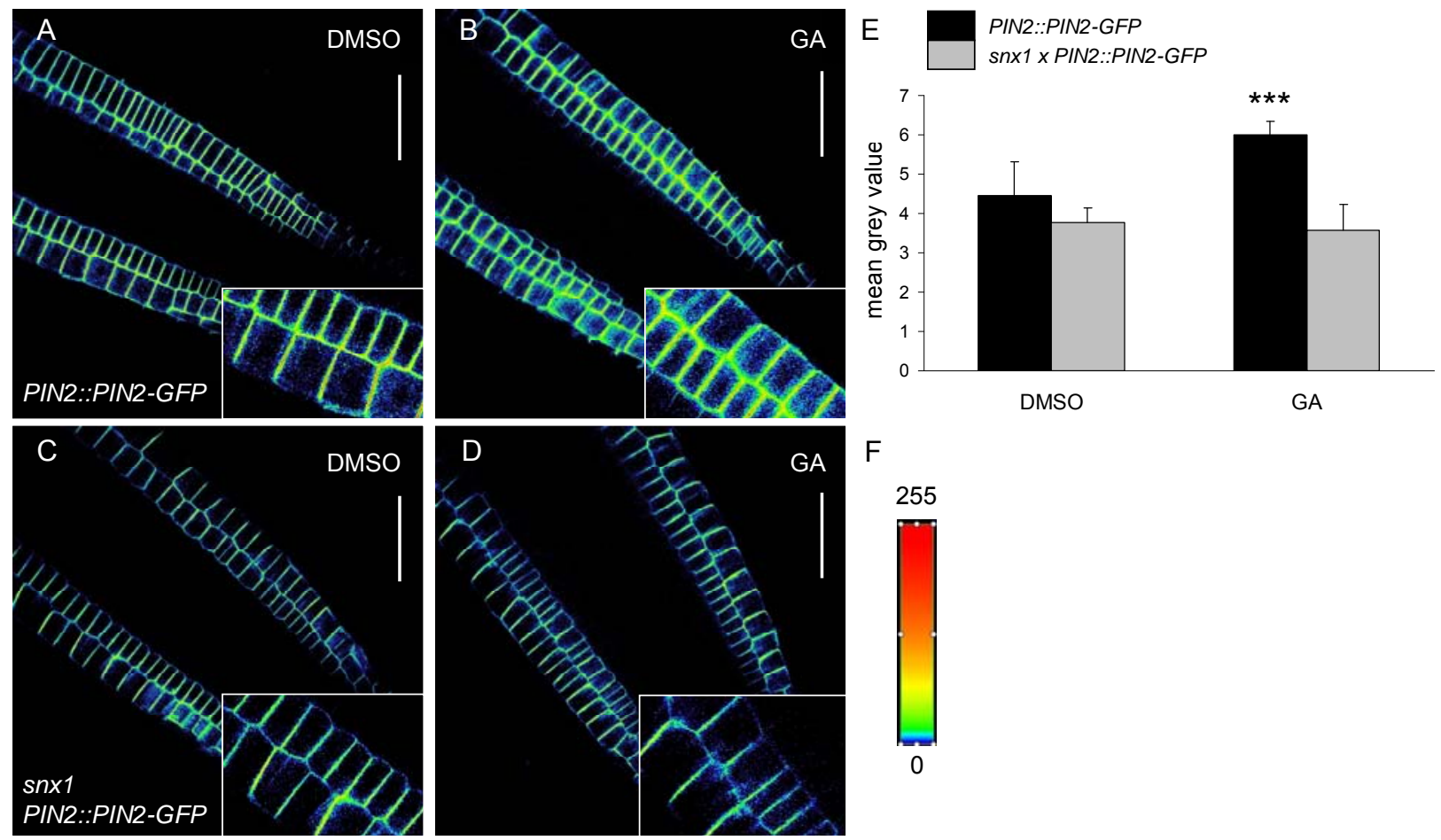

Figure 9. GA mediated stabilization of PIN2 protein is SNX1 dependent.

PIN2::PIN2-GFP and snx1-1 x PIN2::PIN2-GFP seedlings were treated with with (A, C) DMSO (GA solvent); (B, D) $50 \mu \mathrm{M}$ GA for $3 \mathrm{~h}$; (E) quantification of PIN2::PIN2-GFP signal intensities by image analysis in seedlings treated as described in A-D; $(\mathbf{F})$ color code of fluorescence signal intensities shown in A-D; $(n=8$ seedlings per treatment,experiments were repeated three times). Significant differences between treatments are indicated by $* * *$ with $\mathrm{P} \leq 0.001$. Scale bar: $50 \mu \mathrm{m}$.
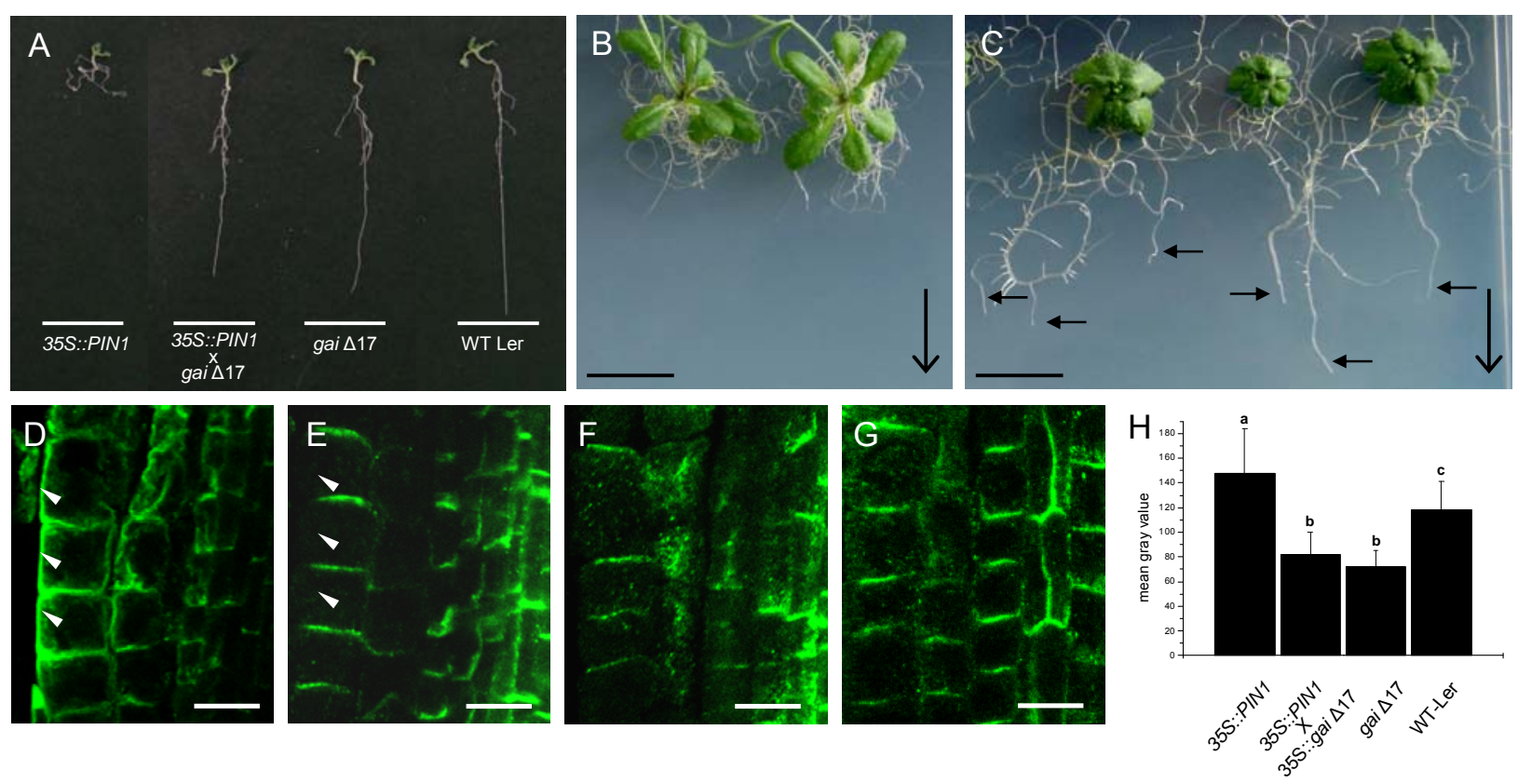

Figure 10. Suppression of the $35 S:: P I N 1$ agravitropic phenotype by gai 17 .

(A) 35S::gai417 was introgressed into 35S::PIN1 background and root growth analysis was done on vertical plates. Root growth of $35 S::$ gai 17 , 35S::PIN1, and wildtype Landsberg erecta seedlings is shown for comparison; (B, C) 35S::PIN1 were germinated on $1 / 2$ MS medium and subsequently sprayed with (B) DMSO and (C) $10 \mu \mathrm{M}$ uniconazole. Pictures were taken two weeks after start of treatments. 
Figure 10. Suppression of the $35 S:: P I N 1$ agravitropic phenotype by gaid17.

(D-G) Simultanous immunolocalization of PIN1 and PIN2 in root tips of (D) $355:: P I N 1$ (E) $355:: P I N 1 x$ 35S::gai417 (F) 35S::gai417 and (G) wildtype Landsberg erecta seedlings. Arrowheads indicate apolar localization of PINs in the PIN1 overexpression line and depletion of PIN1 signal in 35S::PIN1 $x$ 35S::gai417. Antibodies against PIN1 and PIN2 were used in the same sample to show apolar, ectopic PIN1 localization in relation to the PIN2 signal in epidermis cells. (H) quantification of PIN1 and PIN2 plasma membrane signal by image analysis. Significant differences between lines are indicated by different letters with $\mathrm{P} \leq 0.001$. Scale bars A-C: $1 \mathrm{~cm}$ and D-E: $12 \mu \mathrm{m}$, arrows indicate direction of the gravity vector.

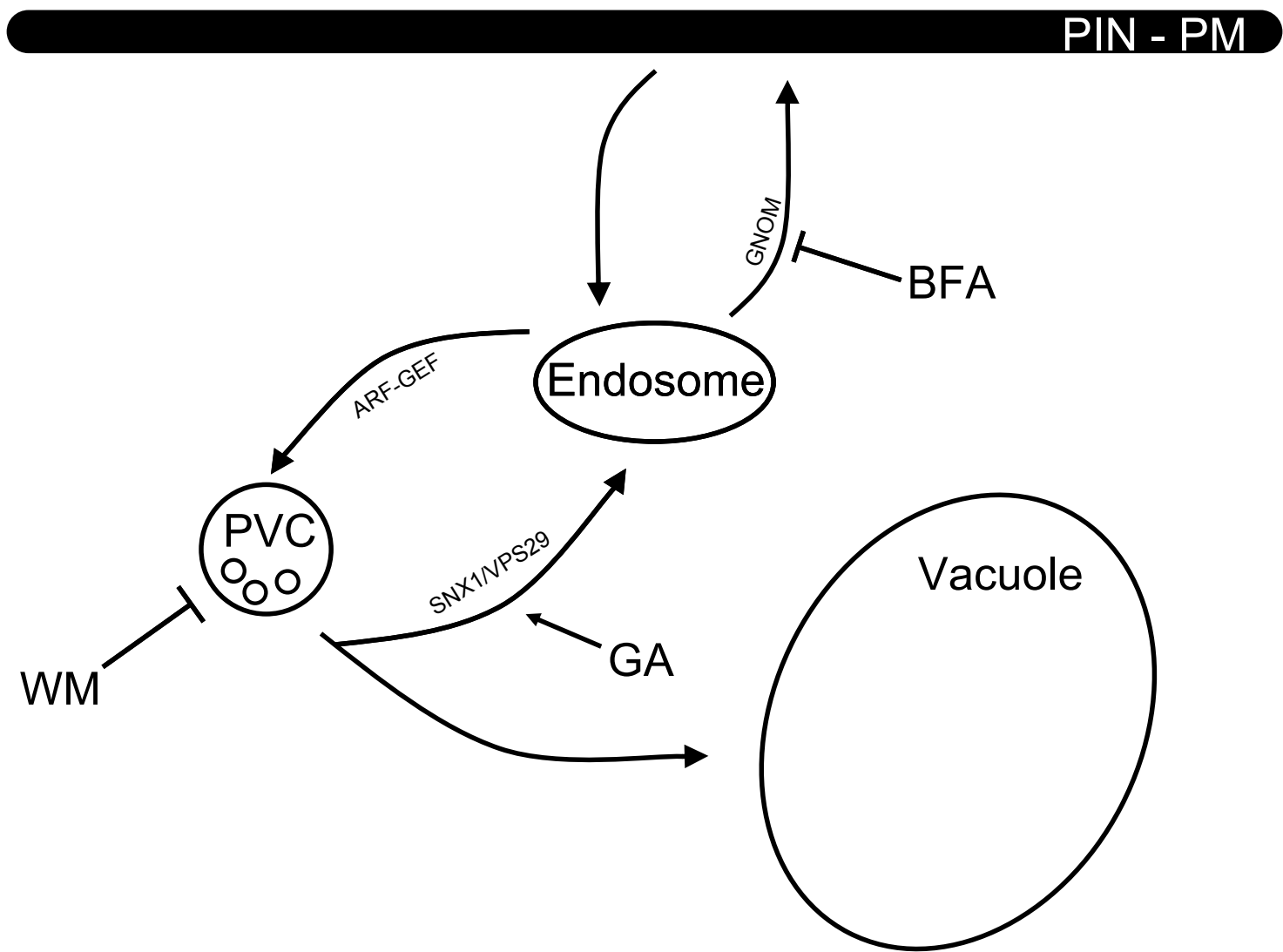

Figure 11. Hypothetical model of GA effect on PIN2 recycling via retromer.

PIN2 endocytosed to an endosomal compartment either cycles back to the plasma membrane via a GNOM dependent pathway or traffics to the lytic vacuole through PVC. The retromer complex allows retrieval of PIN2 from the degradative pathway back to an endosomal compartment. Specific inhibitors are available to interfere with vesicle trafficking. Wortmannin disturbs PVC function and causes formation of wortmannin compartments and BFA inhibits GNOM leading to accumulation of PIN2 in BFA compartments. GA had no effect on PIN2-GFP signal in wortmannin compartments but elevated PIN2-GFP signal in BFA compartments. The data suggest that GA increases retrieval of PIN2 via retromer leading to stabilization of PIN2 at the plasma membrane. 

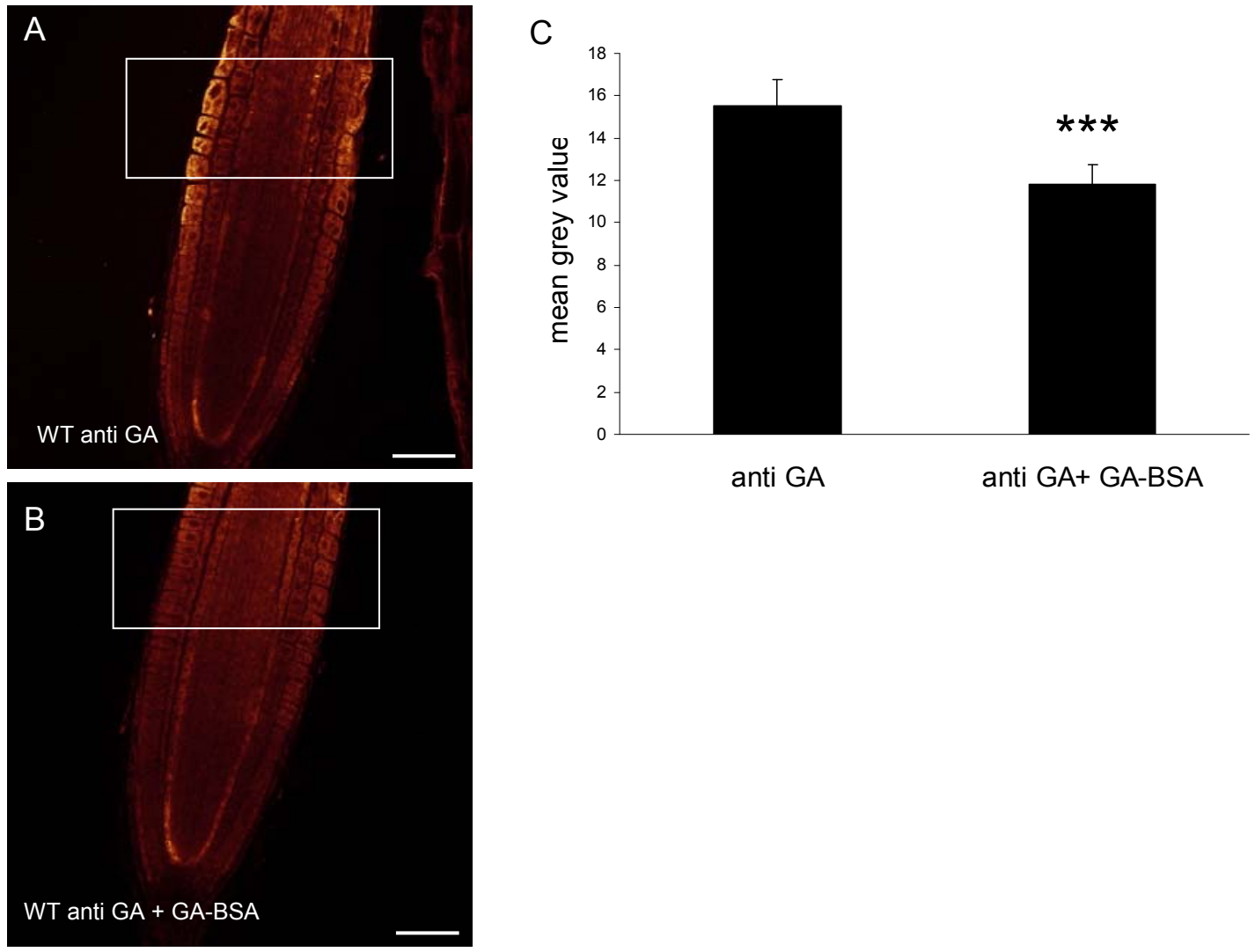

Supplemental Figure 1 Depletion of GA specific immune staining by BSA-coupled GA.

Anti-GA serum was depleted of GA specific antibody by incubation with $\mathrm{GA}_{3}$-BSA conjugate prior to use for immunostaining of roots. (A) immunostaining using non-depleted anti-GA serum; (B) immunostaining using $\mathrm{GA}_{3}$-BSA conjugate depleted anti-GA serum (C). Quantification of immunosignal in the areas indicated in A and B. ( $n=8$ seedlings per treatment, experiments were repeated two times). Significant differences between treatments are indicated by $* * *$ with $\mathrm{P} \leq 0.001$. Scale bar $50 \mu \mathrm{m}$.
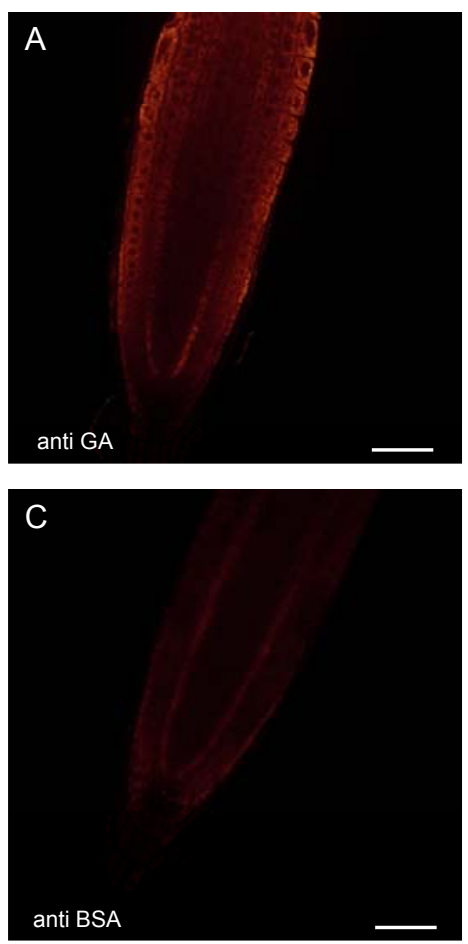

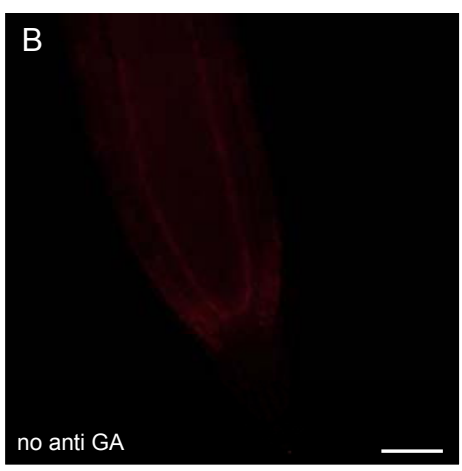

D

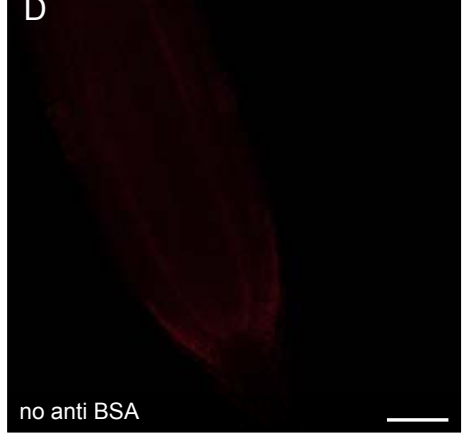

\section{Supplemental Figure 2}

Comparison of immuno staining with anti GA and anti BSA antibody.Immuno staining of roots was performed with antibodies directed against GA and BSA, respectively. (A) anti-GA antibody; (B) primary anti-GA antibody omitted as control; (C) anti-BSA antibody; (D) primary anti-BSA antibody omitted as control. Scale bar: $50 \mu \mathrm{m}$. 

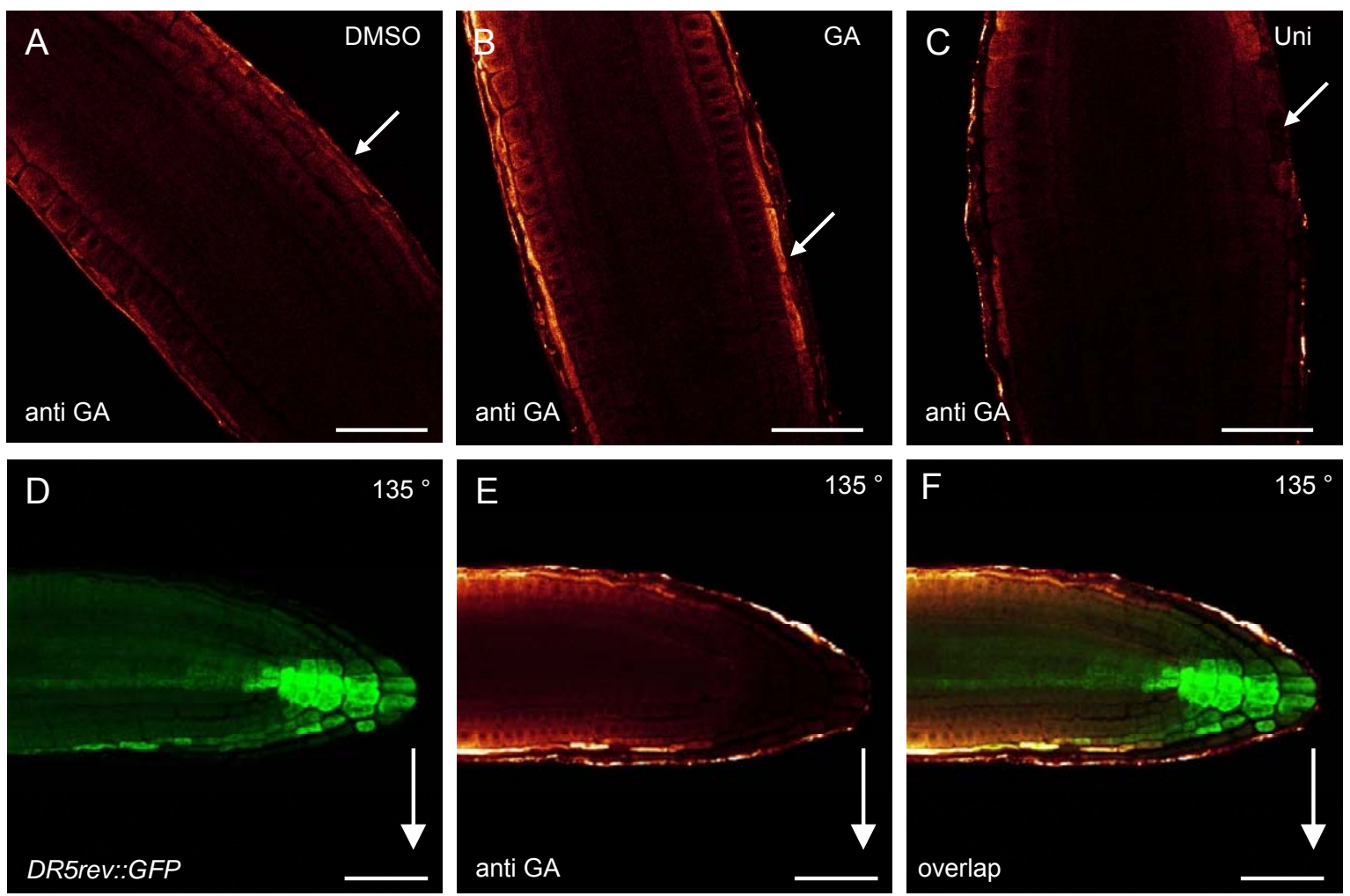

Supplemental Figure 3. Detection of GA localisation in the root tip by immuno staining.

All shown roots were immuno stained with an antibody directed to GA. Seedlings were treated with (A) DMSO; (B) $50 \mu \mathrm{M}$ GA for $3 \mathrm{~h}$; (C) $10 \mu \mathrm{M}$ uniconazole for $2 \mathrm{~d}$, arrows designate detection of GA in A, B and indicate decrease of GA after uniconazole treatment in C; (D- F) immuno staining of gravitropically induced DR5rev::GFP seedlings showing asymmetry of the DR5rev::GFP signal and GA specific immuno staining. (D) GFP signal, (E) signal of GA antibody (F) overlap of signals shown in D and E. Scale bars A- C: $50 \mu \mathrm{m}$; DF: $75 \mu \mathrm{m}$, arrows in D-F indicate direction of the gravity vector. 

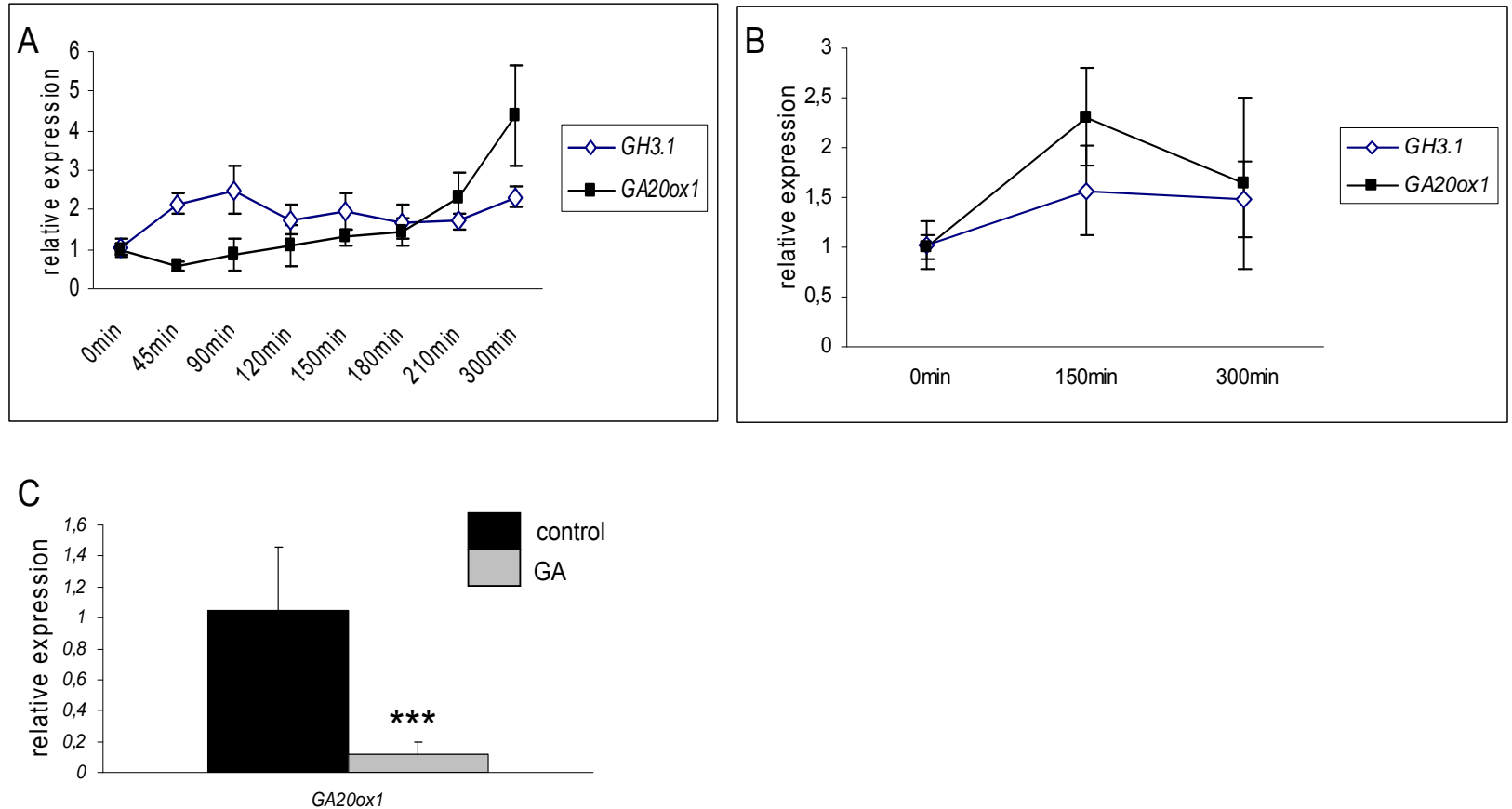

Supplemental Figure 4. Effect of GA treatment and gravistimulation on GA20ox1 and GH3.1 expression in the root.

Realtime PCR analysis was performed with cDNA obtained from gravitropically induced roots, vertically grown roots as controls, and roots treated for $3 \mathrm{~h}$ with $50 \mu \mathrm{M}$ GA. To avoid any influence of phototropic stimulation, the gravitropic experiments were done after transfer to dark. Control experiments indicated that GA20oxl expression was induced by dark treatments per se, but compared to controls the gravitropic stimulus gave a significantly and consistently stronger response during gravitropism. (A) time course of GA20ox1 and GH3.1 expression after gravitropic induction; (B) time course of GA20ox1 and GH3.1 expression in non-gravitropically induced roots after transfer of roots to the dark; (C) GA20oxl expression in roots treated for $3 \mathrm{~h}$ with $50 \mu \mathrm{M}$ GA. (A, B: $\mathrm{n}=4$ pools of roots from $30-40$ seedlings; C: $\mathrm{n}=6$ pools of roots from $30-40$ seedlings).
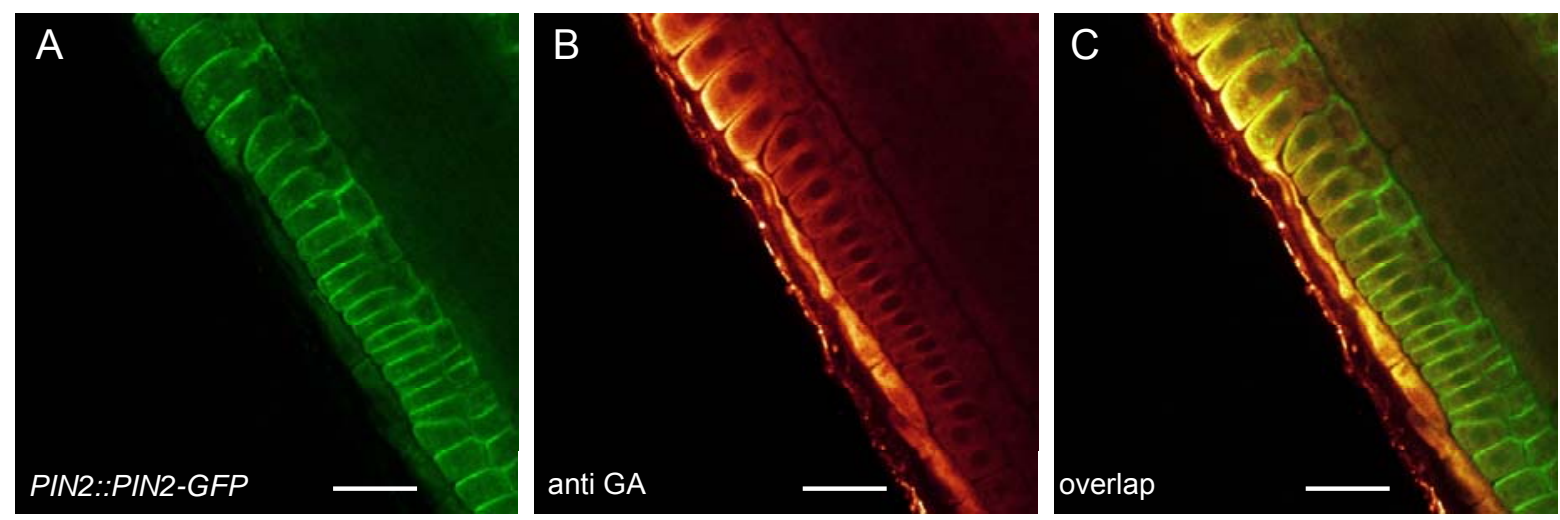

Supplemental Figure 5. Co-localisation of GA and PIN2 in the root tip.

PIN2::PIN2-GFP seedling showing the (A) GFP signal; (B) signal of GA antibody;

(C) co-localisation of signals shown in A and B. Scale bar: $25 \mu \mathrm{m}$. 


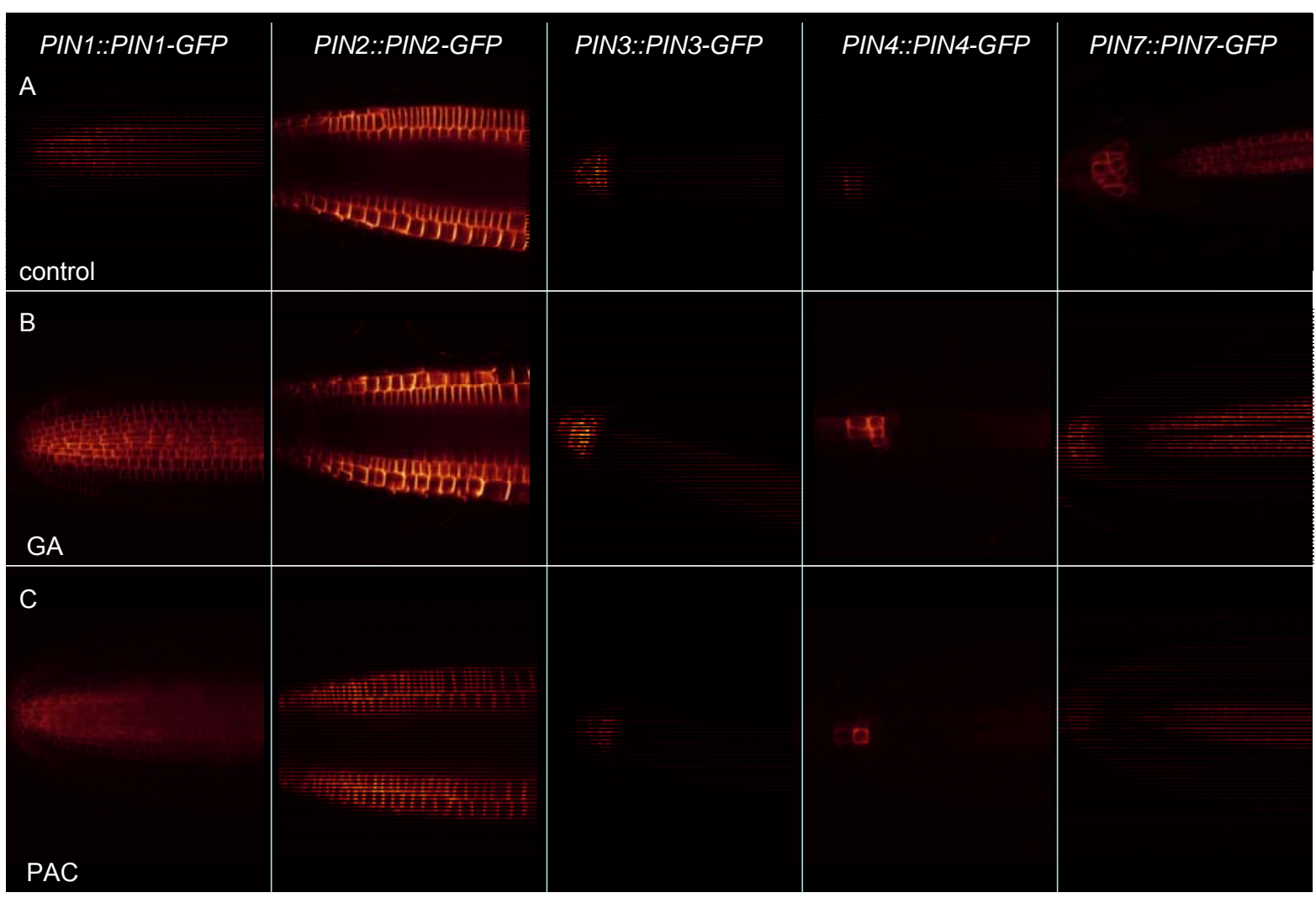

Supplemental Figure 6. Effect of altered GA levels on plasma membrane localized PIN amounts. Arabidopsis lines expressing PIN1, 2, 3, 4, and 7 as GFP fusion under control of the native promoters were treated with (A) DMSO; (B) $50 \mu \mathrm{M}$ GA for $3 \mathrm{~h}$, (C) $10 \mu \mathrm{M}$ paclobutrazole for $2 \mathrm{~d}$.

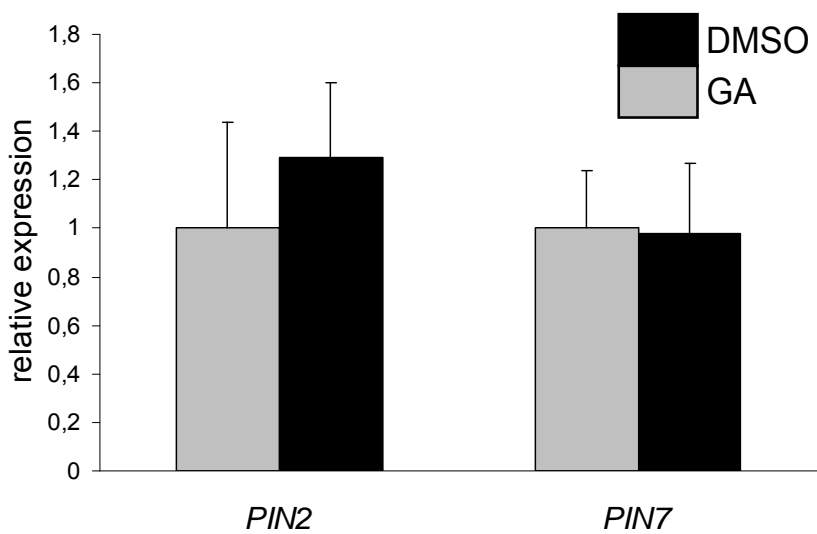

Supplemental Figure 7. Expression analysis of PIN2 and PIN7 by Realtime-PCR in GA treated roots. Realtime PCR analysis was performed with cDNA obtained from control roots and roots treated for $3 \mathrm{~h}$ with $50 \mu \mathrm{M}$ GA, ( $\mathrm{n}=6$ pools of roots from 30 - 40 seedlings). Scale bar: $50 \mu \mathrm{m}$. 

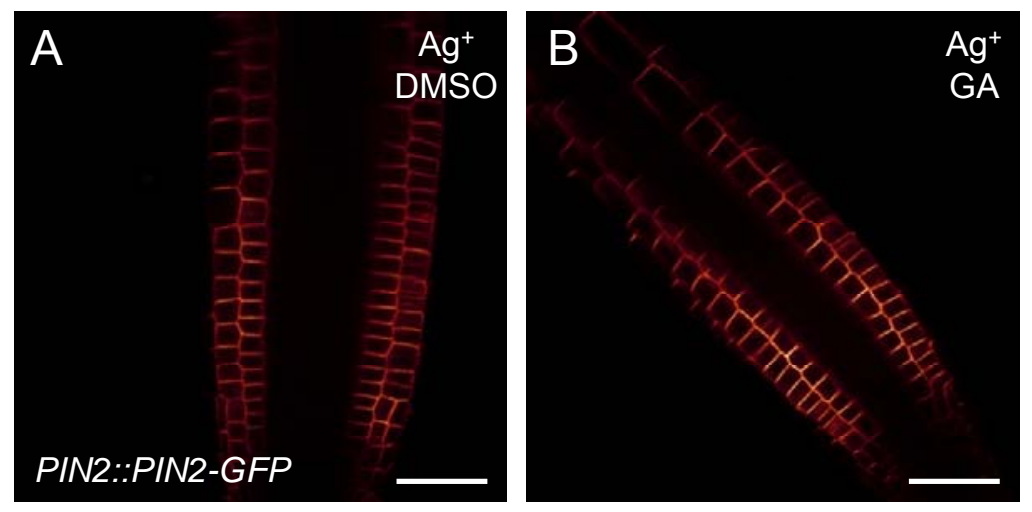

Supplemental Figure 8. GA effect in PIN2::PIN2-GFP seedlings compromised in ethylene signalling. Seedlings were grown on medium containing $20 \mu \mathrm{M} \mathrm{AgNO}$ for $7 \mathrm{~d}$ and treated with (A) DMSO for $3 \mathrm{~h}$ (GA solvent) and (B) $50 \mu \mathrm{M}$ GA for $3 \mathrm{~h}$. Scale bar: $50 \mu \mathrm{m}$.
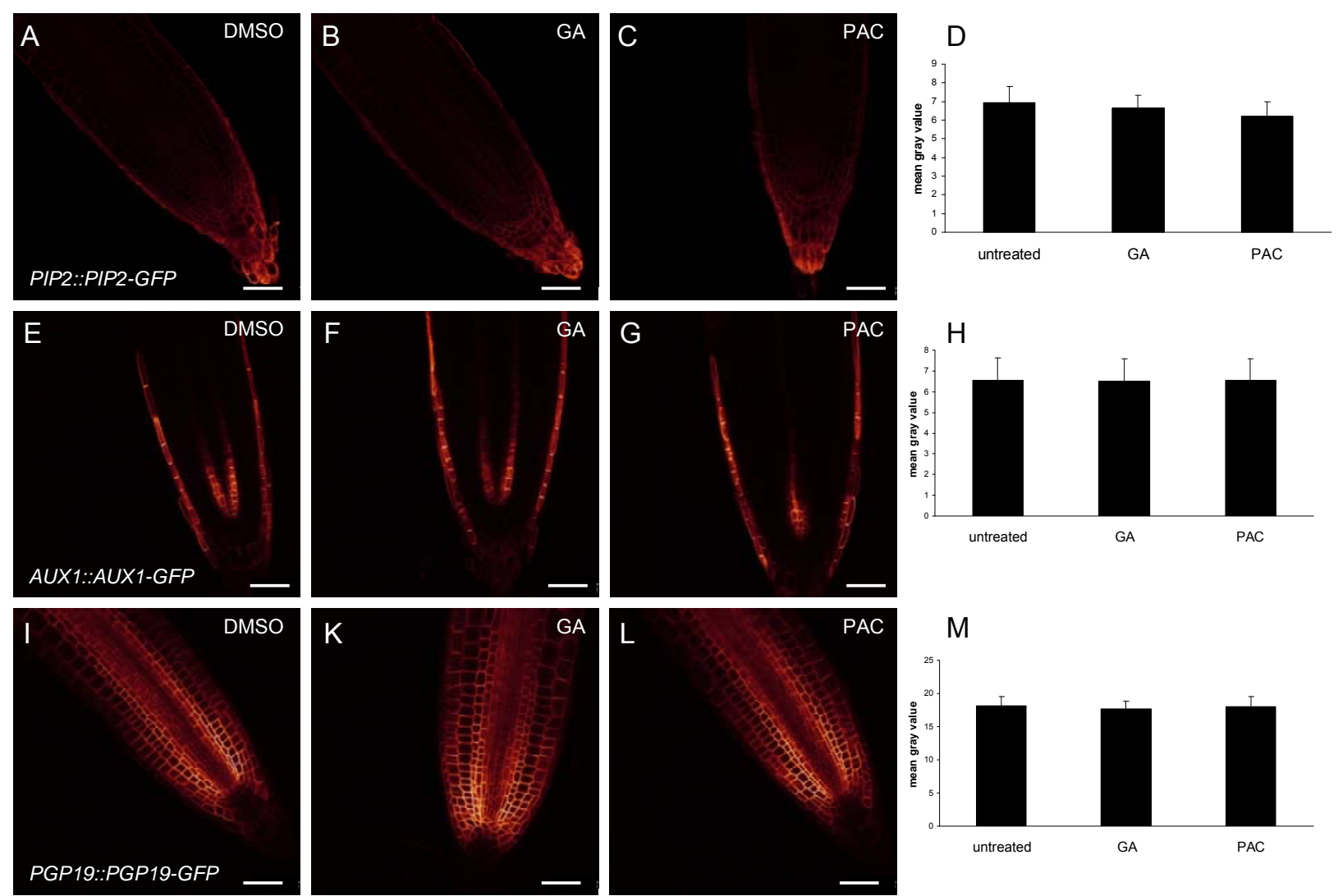

Supplemental Figure 9. Effect of altered GA levels on plasma membrane proteins.

(A-D) PIP2::PIP2-GFP; (E-H) AUX1::AUX1-GFP; (I-M) PGP19::PGP19-GFP; (A, E, I) treatment with DMSO (GA and paclobutrazol solvent) for $3 \mathrm{~h}$; (B, F, K) treatment with $50 \mu \mathrm{M}$ GA for $3 \mathrm{~h},(\mathbf{C}, \mathbf{G}$, L) treatment with $10 \mu \mathrm{M}$ paclobutrazole for $2 \mathrm{~d}$. (D, H, M) quantification of expression by image analysis in analysed lines. Scale bar: $50 \mu \mathrm{m}$. 

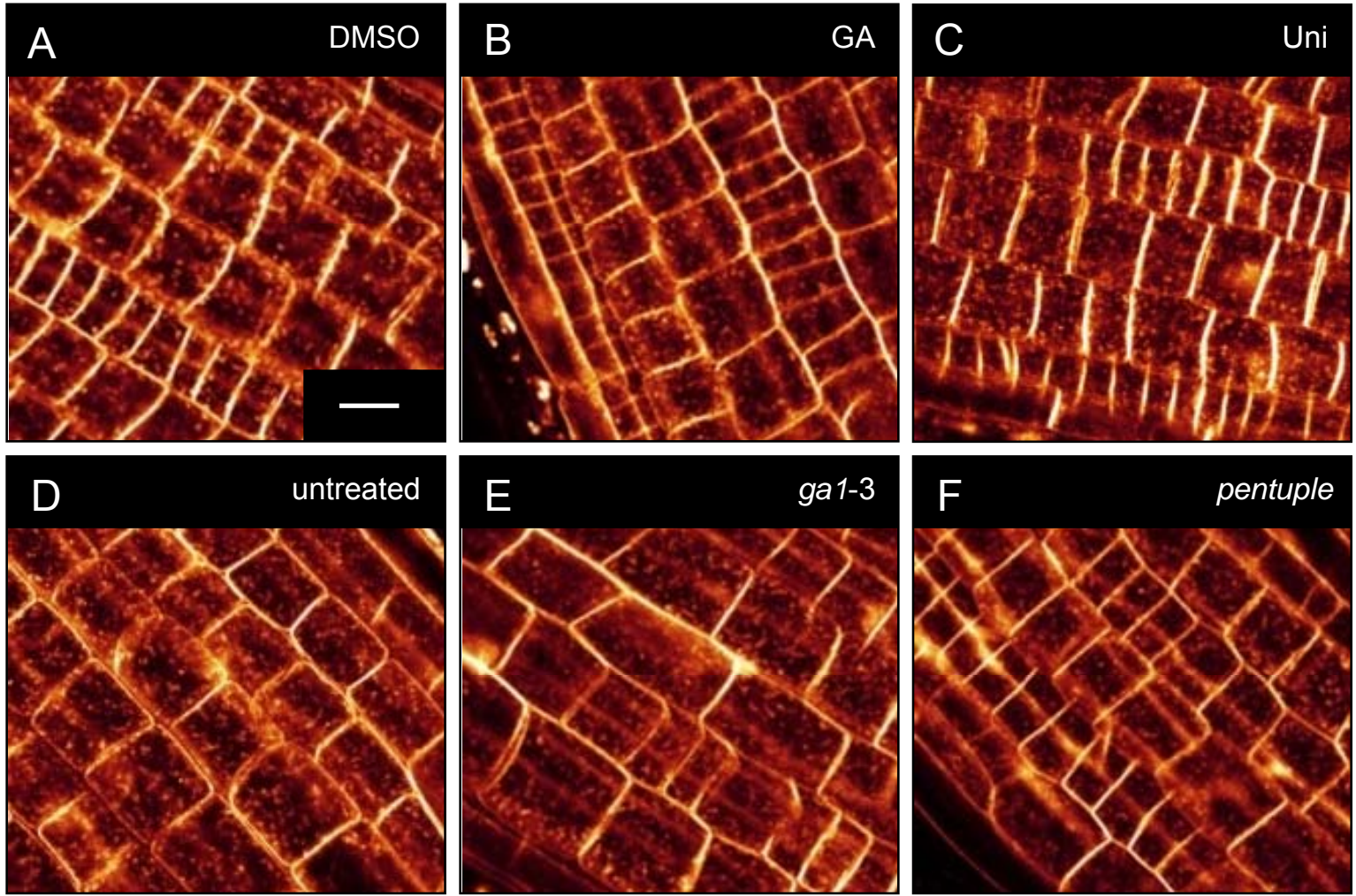

Supplemental Figure 10. Effects of altered GA levels on FM4-64 uptake.

Uptake of the endocytosis marker FM4-64 in roots treated with (A) DMSO (GA and uniconazole control); (B) $50 \mu \mathrm{M} \mathrm{GA}$ for $3 \mathrm{~h}$; (C) uniconazole for $2 \mathrm{~d}$; (D) untreated wildtype control; (E) gal-3 mutant; (F) pentuple mutant. Scale bar: $25 \mu \mathrm{m}$.
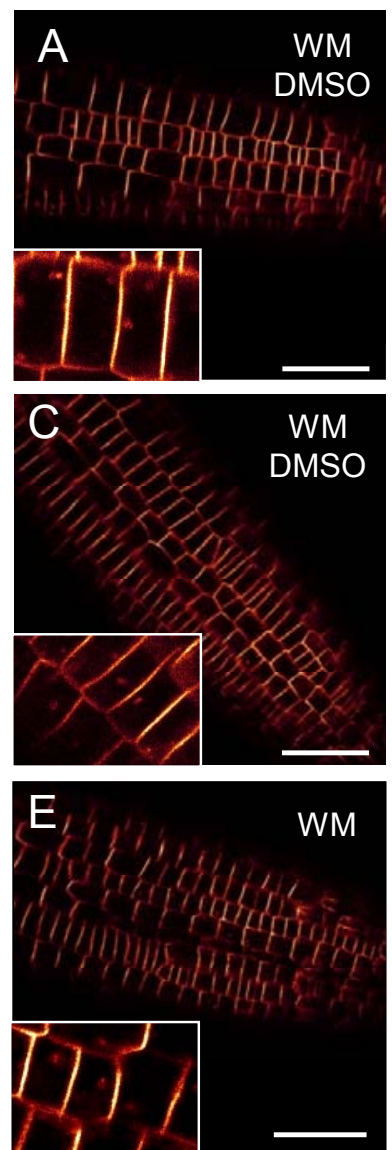
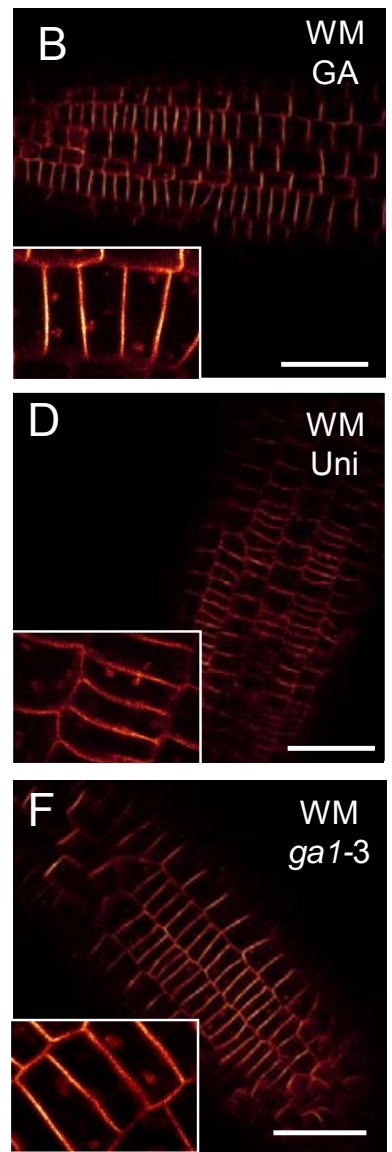

Supplemental Figure 11. Accumulation of PIN2-GFP in wortmannin compartments is not changed by altered GA levels.

PIN2-GFP signal in wortmannin compartments of PIN2::PIN2-GFP seedlings after treatment with (A) DMSO for $3 \mathrm{~h}$ (GA control); (B) 50 $\mu \mathrm{M}$ GA for $3 \mathrm{~h}$; (C) DMSO for $2 \mathrm{~d}$ (Uniconazole control); (D) $10 \mu \mathrm{M}$ Uniconazole for $2 \mathrm{~d}$; (E,F) PIN2-GFP signal in wortmannin compartments of (E) PIN2::PIN2-GFP and (F) PIN2::PIN2-GFP x gal-3 seedlings. Scale bar: $50 \mu \mathrm{m}$. 


\section{Zusammenfassung des Manuskripts}

Auxin und Gibberellin zählen beide zu den klassischen Wachstumshormonen. Da sie ähnliche Wirkbereiche in der Pflanze abdecken, ist eine Vernetzung der beiden Hormone anzunehmen. In vorangegangenen Studien wurde ein direkter Einfluss von Auxin auf die GA-Biosynthese und GA-Perzeption nachgewiesen. In der vorliegenden Arbeit sollte komplementär die Wechselwirkung von GA auf auxinrelevante Prozesse untersucht werden. Der Gravitropismus ist ein ideales System, um dynamische, auxinabhängige Prozesse wie Auxinverteilung und PIN-Endomembranfluss in der Wurzel darzustellen. Um den GA-Gehalt oder die GA-Signaltransduktion in Pflanzen gezielt zu verändern wurden pharmakologische und genetische Manipulationen durchgeführt. Sowohl bei geringeren GA-Gehalten, wie sie nach Uniconazolbehandlung oder in der gal-3 GA-Biosynthesemutante vorliegen, als auch bei erhöhten GAGehalten oder konstitutiv aktivierter GA-Signaltransduktion in der pentuple-Mutante war die gravitrope Krümmungsreaktion der Wurzel schwächer verglichen mit der des Wildtyps oder unbehandelter Kontrollen. In der pentuple-Mutante sind die DELLAGene $R G A, G A I, R G L 1, R G L 2$ und $R G L 3$ durch T-DNA Insertionen defekt (Feng et al., 2008). Zur Visualisierung der asymmetrischen Auxinverteilung während der gravitropen Krümmungsreaktion wurde ein auxinsensitives Promotorkonstrukt $(D R 5:: G F P)$ verwendet. Interessanterweise akkumulierte nach Gravistimulation bei gleichzeitiger GA-Behandlung Auxin symmetrisch, während bei geringeren GAGehalten (Uniconazolbehandlung) keine laterale Auxin Akkumulation erfolgte. Um Veränderungen der endogenen GA-Gehalte während des Gravitropismus zu zeigen, wurde ein GA-sensitiver Reporter ( $R G A:: R G A-G F P)$ verwendet, der bei erhöhten GAGehalten abgebaut wird. Es konnte gezeigt werden, dass parallel zur asymmetrischen Auxinverteilung das RGA-GFP Signal auf der Unterseite gravistimulierter Wurzelspitzen signifikant schwächer wurde. Unterstützend zum indirekten Nachweis der GA-Verteilung durch einen Reporter, konnte ein GA-spezifischer Antikörper etabliert werden, mit dem direkt die endogene GA-Verteilung im Wurzelgewebe visualisiert wurde. Die asymmetrische GA-Verteilung während der gravitropen Krümmungsreaktion konnte durch eine asymmetrische GA-Detektion über den GAspezifischen Antikörper in der Zellteilungs- und Elongationszone der Wurzelepidermis bestätigt werden. Des Weiteren wurden die Effekte von GA auf die PIN-Transkription und -Proteingehalte untersucht. Durch GA-Behandlung veränderte sich die PIN2 
Expression nicht, jedoch zeigten sich veränderte PIN-Proteingehalte nach GA- oder Uniconazolgabe. Damit übereinstimmend zeigte sich gegenüber Kontrollpflanzen ein verzögerter Abbau des dexamethasoninduzierten PIN2-GFP Signals in GA-behandelten Pflanzen. Dieser Stabilisierungseffekt von GA scheint spezifisch für PIN-Proteine zu sein, da andere plasmamembranassoziierte Auxintransporter (AUX1 und PGP19) und ein Aquaporin (PIP2) nicht durch veränderte GA-Gehalte beeinflusst wurden. Der PINProteingehalt der Plasmamembran wird durch eine Balance zwischen Degradation in der lytischen Vakuole und konstitutivem Recycling zurück zur Plasmamembran reguliert (Kleine-Vehn et al., 2008a). Eine Erhöhung der PIN-Proteinmenge an der Plasmamembran kann bei nicht-transkriptioneller Kontrolle durch Erniedrigung der Endozytose, Erhöhung der Exozytose oder verändertes Recycling erhöht werden. Da die Internalisierung von FM4-64, eines Endozytose-Indikators, durch veränderte GAGehalte nicht beeinflusst war, aber mehr PIN2 in BFA induzierten Endosomen akkumulierte, liegt der Schluss nahe, dass bei verstärkter GA-Bildung das PINRecycling vom PVC zurück zu den Endosomen gesteigert war. Um zu testen, ob der Retromer-abhängige Weg für den GA-induzierten Anstieg der PIN-Proteine an der Plasmamembran notwendig ist, wurden die Versuche im Hintergrund einer snxlMutante wiederholt, in der das Retromer-abhängige Recycling unterbrochen ist. In dieser Mutante zeigten sich keine GA-induzierten Effekte auf die PIN2-Proteingehalte. Zur Untermauerung des Einflusses von GA auf den PIN-Proteingehalt und zur Bestimmung der physiologischen Relevanz der GA-vermittelten PIN-Stabilisierung in Pflanzen, wurde eine dominant negative Form von GAI in 35S::PIN1-Pflanzen exprimiert. 35S::PIN1-Pflanzen zeichnen sich durch eine ektopische, apolare PINVerteilung aus. Als Resultat der blockierten GA-Signaltransduktion lag PIN1 wieder polar lokalisiert vor und konnte somit den agravitropen Wurzelphänotyp von 35S::PIN1-Pflanzen komplementieren.

Die Gesamtheit der Daten lässt die Hypothese zu, dass nach Gravistimulation GA auf der Unterseite der Wurzel akkumuliert, wo es die PIN-Stabilität über den Retromerabhängigen Weg beeinflusst und so die Balance zwischen Abbau und Recycling von PIN-Proteinen mitbestimmt. 


\section{Zusätzliche Ergebnisse}

Im vorangegangenen Manuskript „Gibberellin Regulates Root Gravitropism via Modulation of PIN Stability“ wurde der Einfluss von GA auf die PIN-Stabilität während der gravitropen Krümmungsreaktion der Wurzel gezeigt. Die veränderten PIN-Gehalte lassen auf einen veränderten Auxintransport und Auxinverteilung schließen. Die Ergebnisse zum Einfluss von GA auf Auxintransport und -verteilung werden daher im folgenden Abschnitt dargestellt.

\subsection{Redundante Funktion der DELLA-Gene}

DELLA-Proteine sind transkriptionelle Repressoren, die GA-vermittelte Wachstumsprozesse regulieren und das Wachstum unterdrücken. Erhöhte GA-Gehalte führen zum Abbau der DELLA-Proteine über das 26S-Proteasom und geben somit die Transkription GA-abhängiger Gene frei. Die Transkription von DELLA-Genen nahm nach GA-Behandlung ab (Abb.6 A). Dieser Effekt war zuvor nur anhand der Proteinmengen beschrieben worden (Feng et al., 2008). Die Akkumulation von DELLA-Proteinen wird somit nach GA-Gabe sowohl durch ihren Abbau (Feng et al., 2008) als auch durch gleichzeitige Transkriptabnahme verringert. Um die Mutante rga/gai, in der zwei DELLA-Gene ausgeschaltet sind, zu charakterisieren, wurde das Transkriptionsprofil der übrigen DELLA-Gene im Hintergrund dieser Mutante erstellt. Dabei zeigten sich erhöhte Expressionen der übrigen $R G L 1-2-3-G e n e$ in der rga/gaiMutante, die vermutlich dem Verlust von $R G A$ und $G A I$ entgegensteuern (Abb. $6 \mathrm{~B}$ ). Demnach ist die rga/gai-Mutante eine Pflanzenlinie, in der, je nachdem welches DELLA-Gen betrachtet wird, entweder die GA-Signaltransduktion bei $R G A$ und $G A I$ konstitutiv aktiviert oder aber durch erhöhte $R G L$-Expression unterdrückt wird. Falls die unterschiedlichen DELLA-Proteine spezifische Funktionen wahrnehmen, sind in der rga/gai Doppelmutante also gegensätzliche Effekte auf verschiedene GA-regulierte Prozesse zu erwarten. 

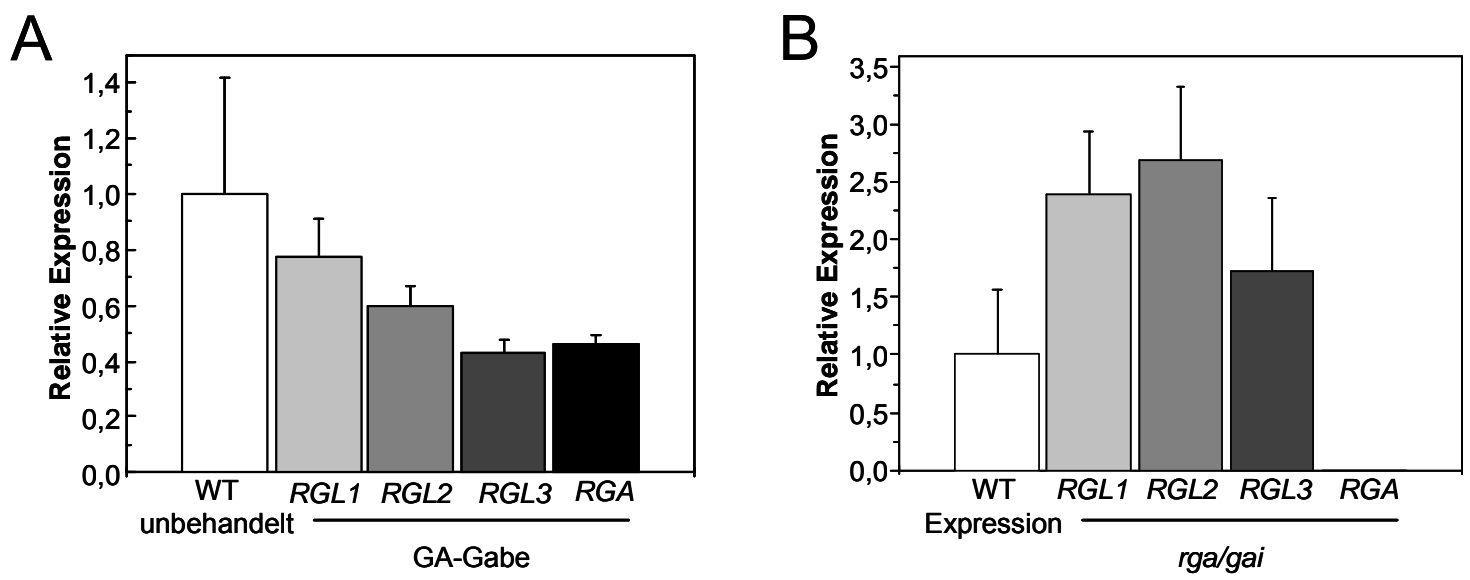

Abb. 6: Expressionsanalyse von vier DELLA-Genen in der Wurzel. (A) Expression von $R G L 1, R G L 2$, $R G L 3$ und $R G A$ nach einer 3 h GA-Behandlung. (B) Expression von $R G L 1, R G L 2, R G L 3$ und $R G A$ in der Doppelmutante rga/gai. In der Doppelmutante sind keine Transkripte von $R G A$ detektierbar. Die Daten repräsentieren Mittelwerte und SD von einem Experiment mit 3 biologischen Wiederholungen.

\subsection{DELLA-abhängige Wechselwirkung zwischen GA-Signaltransduktion und Auxintransport}

Der Zusammenhang von GA und Auxintransport wurde bislang nur in Sprossabschnitten von Pisum sativum untersucht und dabei eine fördernde Wirkung von GA auf den Transport ${ }^{14} \mathrm{C}$-markierten Auxins gezeigt (Jacobs und Case, 1965). Mit Hilfe von tritiiertem IAA sollte nun der Auxintransport in Wurzeln von Arabidopsis thaliana-Linien mit veränderten GA-Gehalten und veränderter GA-Signaltransduktion nachverfolgt und quantifiziert werden. Dafür wurden 8 Tage alte A. thaliana Keimlinge zunächst auf vertikalen 1/2 MS-Platten angezogen. Die Quelle mit dem radioaktiv markierten Auxin wurde auf den Übergang von Spross zu Wurzel platziert und nach $18 \mathrm{~h}$ das transportierte $\left[{ }^{3} \mathrm{H}\right] \mathrm{IAA}$ im unteren Wurzelsegment im Szintillationszähler quantifiziert (Abb. 7A). Als Kontrolle des Transportversuchs bzw. des polaren Auxintransports, wurde N-1-Naphthylphthalamid Säure (NPA), ein pharmakologischer Inhibitor des IAA-Effluxes, eingesetzt. Durch NPA-Gabe konnte der gemessene Auxintransport um bis zu 35\% gehemmt werden (Abb. 7B). Wurde durch exogene GAApplikation die GA-Konzentration erhöht, verringerte sich der Auxintransport. Unterbrechen der GA-Biosynthese mit Uniconazol, das zu einer geringeren GAKonzentration in der Pflanze führt, erhöhte den Auxintransport (Abb. 7C). Ergänzend zu den durch pharmakologische Behandlung erhobenen Daten wurde ein Ansatz mit der GA-Signaltransduktionsmutante pentuple und der GA-Biosynthesemutante gal-3 
durchgeführt. Die genetische Beeinflussung von GA-Signaltransduktion und GABiosynthese hatte den gleichen qualitativen Effekt auf den Auxintransport wie die pharmakologischen Behandlungen: Durch konstitutiv aktivierte GA-Signaltransduktion wurde die Transportrate gehemmt, wohingegen durch geringere endogene GA-Gehalte die Transportrate erhöht wurde (Abb.7D). Diese Modulierung des Auxintransports durch GA ist DELLA-abhängig, da in der pentuple-Mutante keine weitere Hemmung durch GA-Gabe erreicht werden konnte (Abb. 7 E). Da Insertionsmutanten einzelner DELLA-Gene oder entsprechende Überexprimierer keine Unterschiede im Auxintransport aufweisen (Daten nicht gezeigt), wurden Doppel- und Tripelinsertionslinien der DELLA-Proteine verwendet, um eine Gruppe von DELLAProteinen identifizieren zu können, die verantwortlich für die Transportmodulierung sind. In der rgll-2-3-Mutante wurde ein verringerter Transport nachgewiesen. Da in der rga/gai-Mutante mit erhöhter RGL1-2-3 Expression ein verstärkter Transport gemessen wurde, ist aus den Ergebnissen zu schließen, dass RGL1-2-3 den Auxintransport positiv beeinflusst (Abb. 7F). 
A
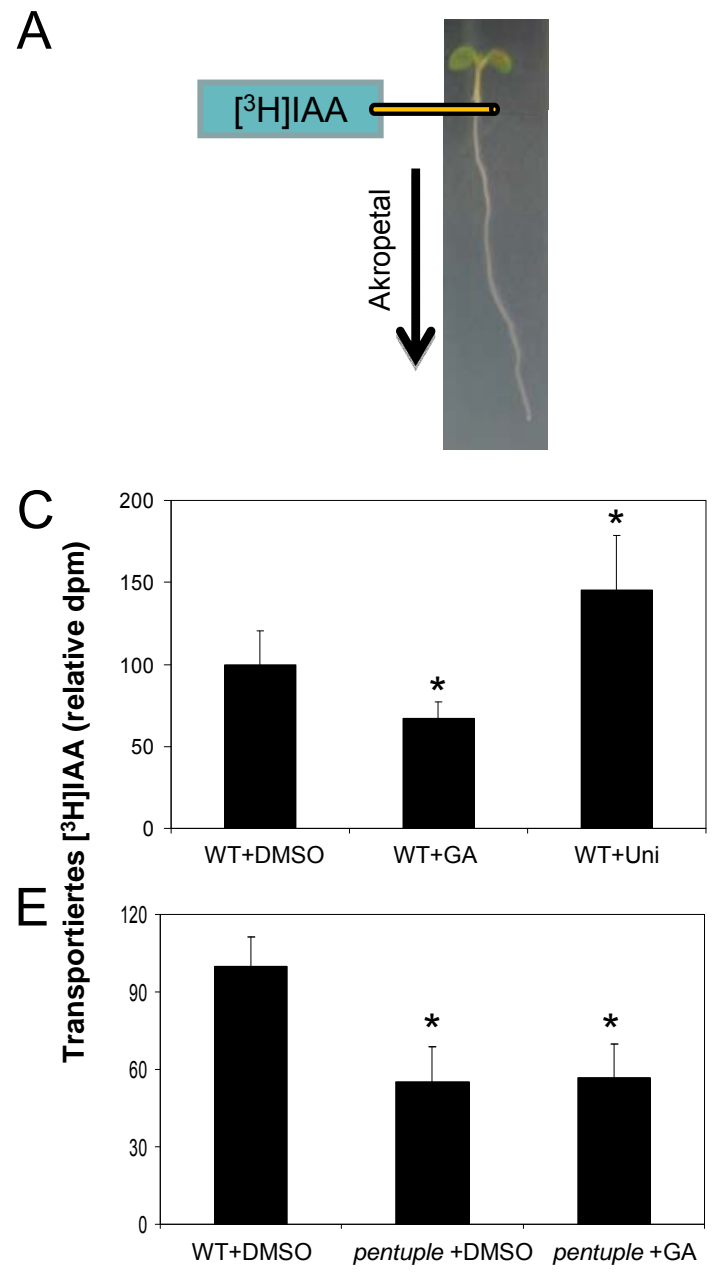

B

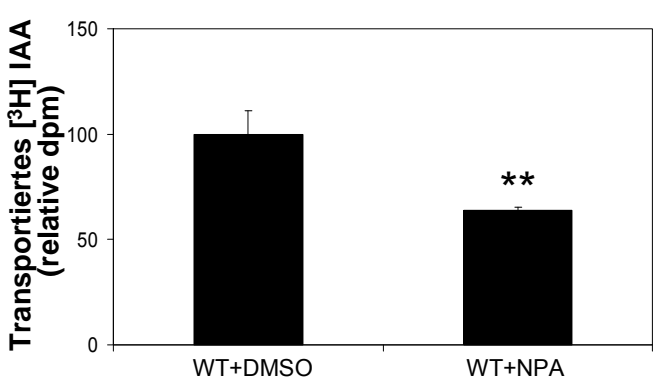

D

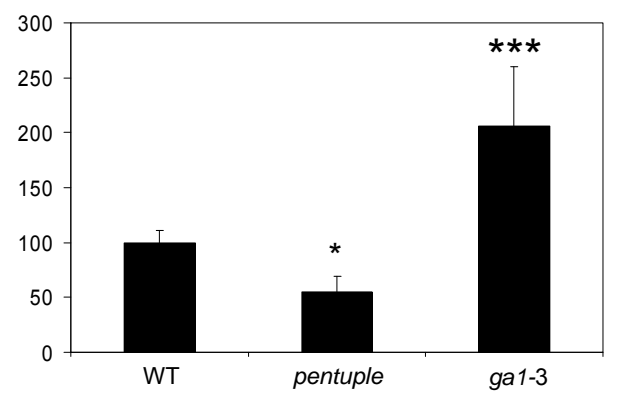

$\mathrm{F}$

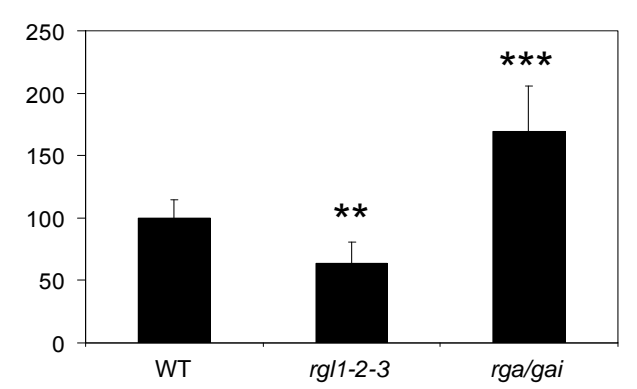

Abb. 7: Auxintransport nach Manipulation der internen GA-Gehalte oder der GA-Signaltransduktion. (A) Schematische Darstellung des akropetalen Auxintransport-Versuchs. Die $\left[{ }^{3} \mathrm{H}\right]-\mathrm{IAA}-\mathrm{Quelle}$ ist auf den Übergang von Wurzel zu Spross platziert. Nach $18 \mathrm{~h}$ wird das untere Wurzelsegment mit einem Abstand von $1 \mathrm{~cm}$ zur $\left[{ }^{3} \mathrm{H}\right]$-Auxinquelle geerntet und die Radioaktivität im Szintillationszähler quantifiziert. (B) Inhibierung des Auxintransports durch NPA als Kontrolle. (C) Modulierung des Auxintransports durch pharmakologische Behandlung mit GA, oder Uniconazol, einem GA-Biosynthese Inhibitor. (D) Auxintransport in der pentuple-Mutante mit konstitutiver aktivierter GA-Signaltransduktion und der gal-3-Mutante mit verringerten endogenen GA-Gehalten. (E) Effekt von GA auf die DELLA pentupleMutante. (F) Auxintransport in der Tripelmutante rgll-2-3 und in der Doppelmutante rga/gai. Den Kontrollen wurden $100 \%$ dpm zugeordnet und die Behandlungen oder Mutanten relativ dazu gestellt. Die Daten repräsentieren Mittelwerte und SD von einem repräsentativen Experiment $(n=3)$ mit jeweils 8 biologischen Wiederholungen. Sternchen symbolisieren einen signifikanten Unterschied zwischen der WT-Kontrolle und den Mutanten oder den pharmakologischen Behandlungen entsprechend des student's $t$-tests $(*: \mathrm{p} \leq 0,1 ; * * \mathrm{p} \leq 0,01 ; * * *: \mathrm{p} \leq 0,001)$. 


\subsection{GA-stabilisierte PIN-Proteine verhindern die Insertion de novo synthetisierter PIN-Proteine an der Plasmamembran}

Die im Manuskript „Gibberellin Regulates Root Gravitropism via Modulation of PIN Stability“ enthaltenen Daten zeigten, dass GA-Gabe das Retromer-vermittelte Recycling von PIN-Proteinen steigert und PIN-Proteine, die eigentlich zum Abbau in der Vakuole bestimmt waren, zurück an die Plasmamembran befördert. Da Pflanzen mit erhöhten GA-Gehalten oder konstitutiv aktiver GA-Antwort eine höhere Konzentration von PINProteinen an der Plasmamembran bei gleichzeitig verringertem Auxintransport zeigten, wurde die Hypothese aufgestellt, dass „alte“, nicht mehr funktionale PIN-Proteine durch das gesteigerte Recycling den Platz an der Plasmamembran für de novo synthetisierte Proteine blockieren. Um dies $\mathrm{zu}$ untersuchen wurde eine Dexamethason (DEX)induzierbare PIN2-GFP-Linie verwendet. Nach einer Vorbehandlung mit GA sollten die endogenen PIN-Proteine stabilisiert werden und dadurch den Platz für die zeitversetzt DEX-induzierten PIN2-GFP-Proteine blockieren. In Abbildung $7 \mathrm{~A}$ ist die typische ektopische PIN2-GFP Lokalisierung nach Expression unter Kontrolle des nicht nativen DEX-Promotors zu beobachten. Nach GA-Behandlung ist ein signifikanter Verlust der Fluoreszenz in dem Bereich festzustellen (hervorgehoben durch die weiße Ellipse), in dem endogene PIN3, PIN4 und PIN7 lokalisiert sind (Abb. 8 B). 

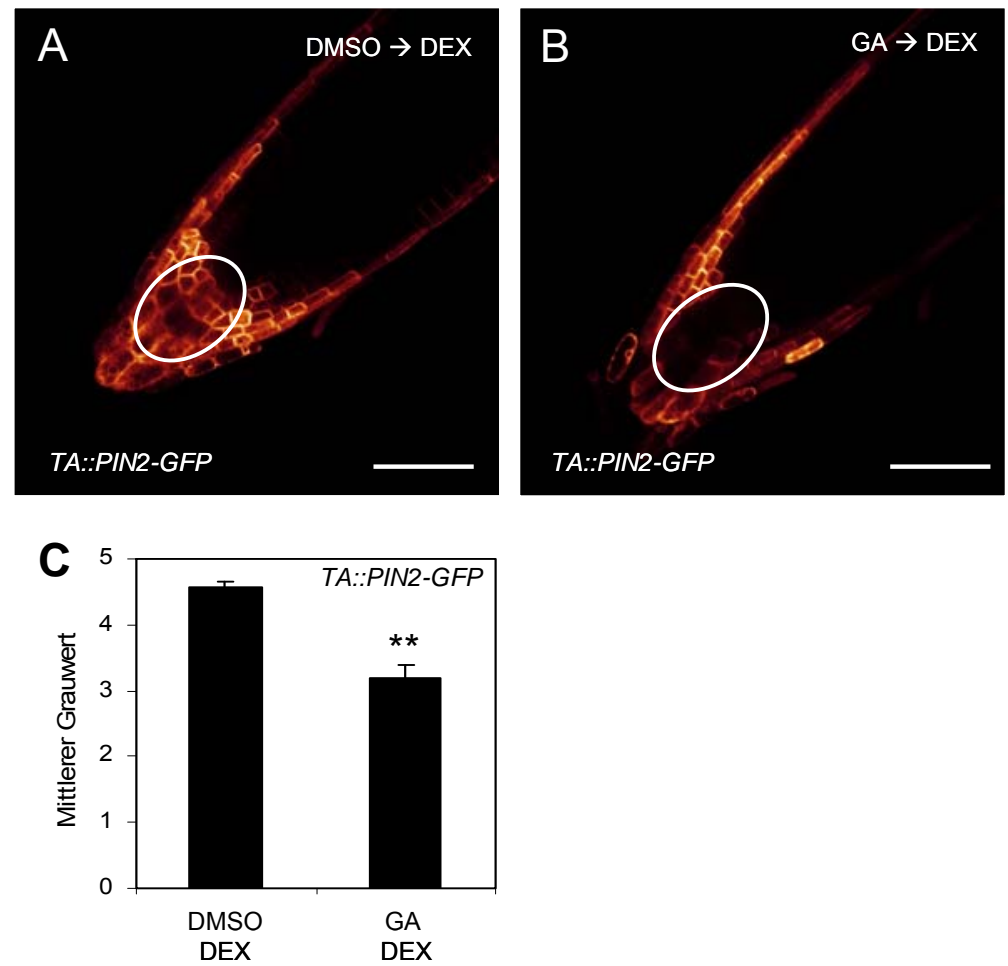

Abb. 8: Vorbehandlung mit GA unterdrückt die Expression von zeitversetzt induziertem PIN2-GFP in der Wurzelspitze. Pflanzen wurden zuerst $24 \mathrm{~h}$ mit GA, bzw. die Kontrollpflanzen mit der gleichen Konzentration des GA-Lösungsmittels (DMSO) behandelt, bevor durch eine $24 \mathrm{~h}$ DEX-Induktion PIN2GFP ektopisch exprimiert wurde. (A) Kontrollbehandlung mit DMSO. Typische ektopische Verteilung von PIN2-GFP in der Wurzelspitze unter Kontrolle des nicht nativen Promotors. (B) PIN2-GFP Expression nach einer GA Vorbehandlung. Die Ellipse deutet den Bereich an, in dem das Fluoreszenzsignal in (C) quantifiziert wurde. Der Maßstab in A und B entspricht $50 \mu \mathrm{m}$. Die in A und B gezeigten Bilder sind repräsentativ für 3 Experimente $(n=8)$. Die Daten in $C$ repräsentieren Mittelwerte und $\mathrm{SD}$ von einem repräsentativen Experiment mit jeweils 8 biologischen Wiederholungen. Sternchen symbolisieren einen signifikanten Unterschied zwischen der DMSO-Kontrolle und der GAVorbehandlung entsprechend des student's $t$-tests $(* *: \mathrm{p} \leq 0,01)$.

\subsection{Synergistische Wirkung von GA und Auxin auf das Auxinmaximum in der Wurzelspitze und das Wurzelwachstum}

Um zu testen, ob die Modulierung des Auxintransports auch einen Effekt auf die Auxinverteilung und auxinabhängige Prozesse hat, wurden transgene Linien verwendet, die GFP unter Kontrolle des synthetischen, auxinsensitiven Promotors DR5 exprimieren. In diesen Linien wurde die Inhibierung des Wurzelwachstums unter Einfluss von erhöhten Auxingehalten untersucht. Der synthetische DR5-Promotor zeigt die Auxinantwort einer Zelle und wird verwendet, um Rückschlüsse auf die Auxinverteilung zu ziehen (Ulmasov et al., 1997). Für die hier gezeigten Experimente wurden Pflanzen zunächst für 8 Tage auf vertikal orientierten Agarplatten angezogen, deren Festmedien mit den jeweiligen Hormonen (siehe 9.4) versetzt waren wie 
angegeben. GA alleine hatte einen nur geringen Effekt auf die DR5::GFP Expression, wohingegen das Auxin 1-Naphthylessigsäure (NAA) zu einer starken GFPAkkumulation in der Wurzelspitze führte. Die Kombination aus GA und NAA führte zu einem weit stärkeren Signal als die einzelnen Hormonbehandlungen zusammengenommen (Abb. 9 A-E). Dieser mehr als additive Effekt von GA und NAA spiegelte sich auch in der verstärkten Inhibierung der Wurzelelongation wider (Abb. 9 F).
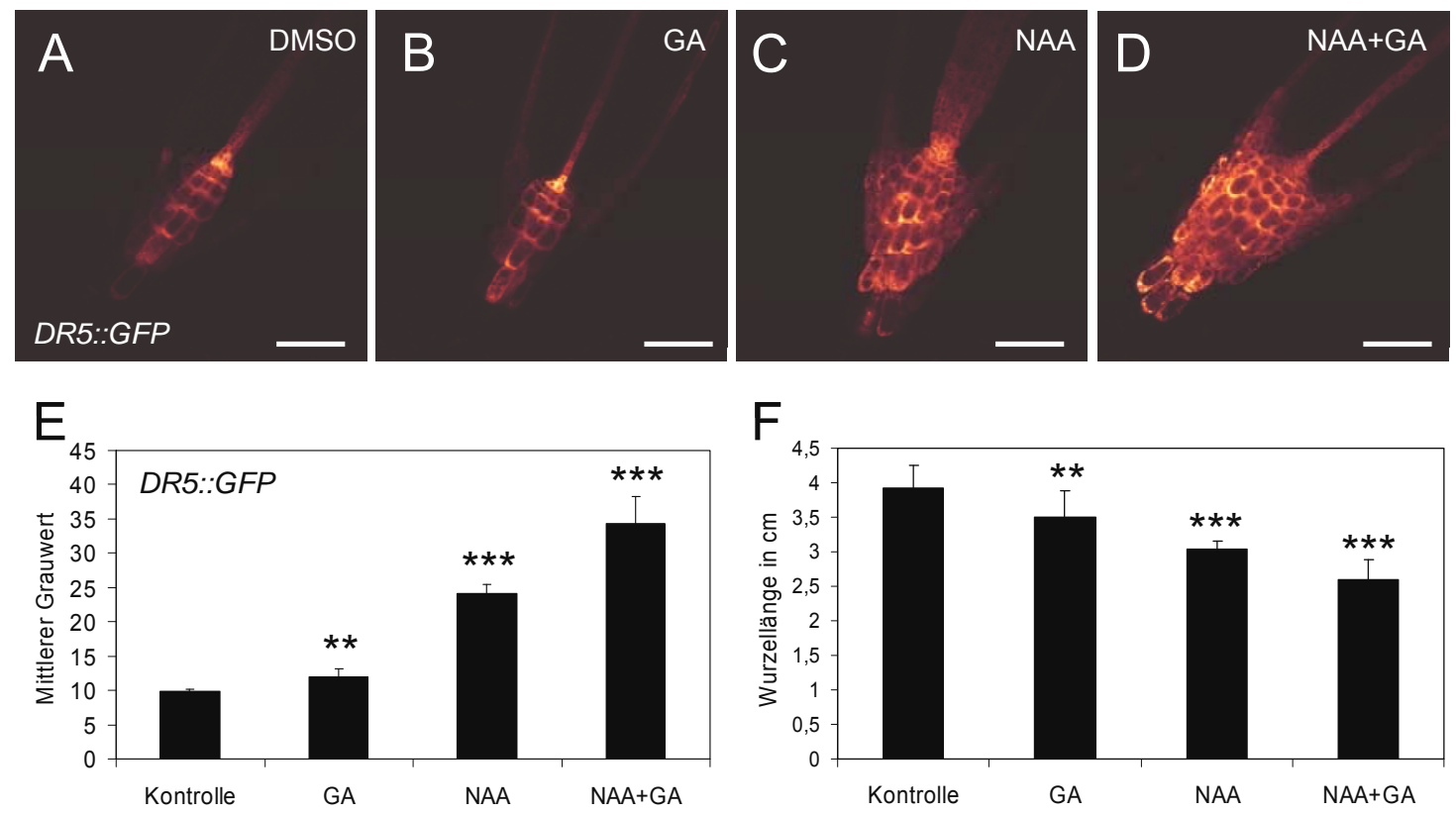

Abb. 9: Effekt von GA und NAA auf das Wurzelwachstum und auxinvermittelte DR5::GFP-Expression in Arabidopsis thaliana. Pflanzen wurden vertikal auf $1 / 2$ MS Medium, mit den jeweiligen Hormonen versetzt, angezogen und nach 8 Tagen GFP-Fluoreszenz und Wurzelwachstum quantifiziert. (A-D) DR5::GFP-Expression in Wurzelspitzen nach GA, NAA und gleichzeitiger GA- und NAA-Gabe. (E) Quantifizierung des Fluoreszenzsignals aus A-D. (F) Wurzellängen von Keimlingen, die wie unter A-D angegeben behandelt wurden. Der Maßstab in A-D entspricht $50 \mu \mathrm{m}$. Die in A -D gezeigten Bilder sind repräsentativ für 3 Experimente $(n=8)$. Die Daten in $E$ und $F$ repräsentieren Mittelwerte und SD von einem repräsentativen Experiment mit jeweils 8 biologischen Wiederholungen. Sternchen symbolisieren einen signifikanten Unterschied zwischen der Kontrolle und den pharmakologischen Behandlungen entsprechend des student's $t$-tests $(* *: \mathrm{p} \leq 0,01 ; * * *: \mathrm{p} \leq 0,001)$.

\subsection{Die GA-Biosynthese Mutante ga1-3 zeigt geringere Auxingehalte und verminderte Sensitivität gegenüber exogen appliziertem Auxin in der Wurzel}

Neben den im vorigen Abschnitt beschriebenen Effekten erhöhter GA-Gehalte auf die Auxinverteilung der Wurzelspitze sollten auch Effekte erniedrigter GA-Antworten untersucht werden. Hierzu wurde die GA-Biosynthese Mutante gal-3 verwendet, die 
sich durch geringe endogene GA-Gehalte auszeichnet (Wilson et al., 1992; Sun und Kamiya, 1994). Der auxinsensitive Reporter DR5::GFP wurde im gal-3 Hintergrund etabliert und die Verteilung der GFP-Fluoreszenz dokumentiert. In der gal-3-Mutante akkumulierte weit weniger GFP in der Wurzelspitze als in den Wildtyp-Kontrollen (Abb. 10 B). Diese Beobachtung stimmt mit verringerten Auxingehalten in Folge geringer endogener GA-Gehalte überein. Die geringeren Auxingehalte in der Wurzel führten auch zu einem besseren Wachstum auf mit NAA versetztem Medium. Das Wurzelwachstum der Kontrolle wurde um $40 \%$ gehemmt, wohingegen das Wachstum der gal-3-Mutante nur um $20 \%$ inhibiert wurde (Abb. 10 C).
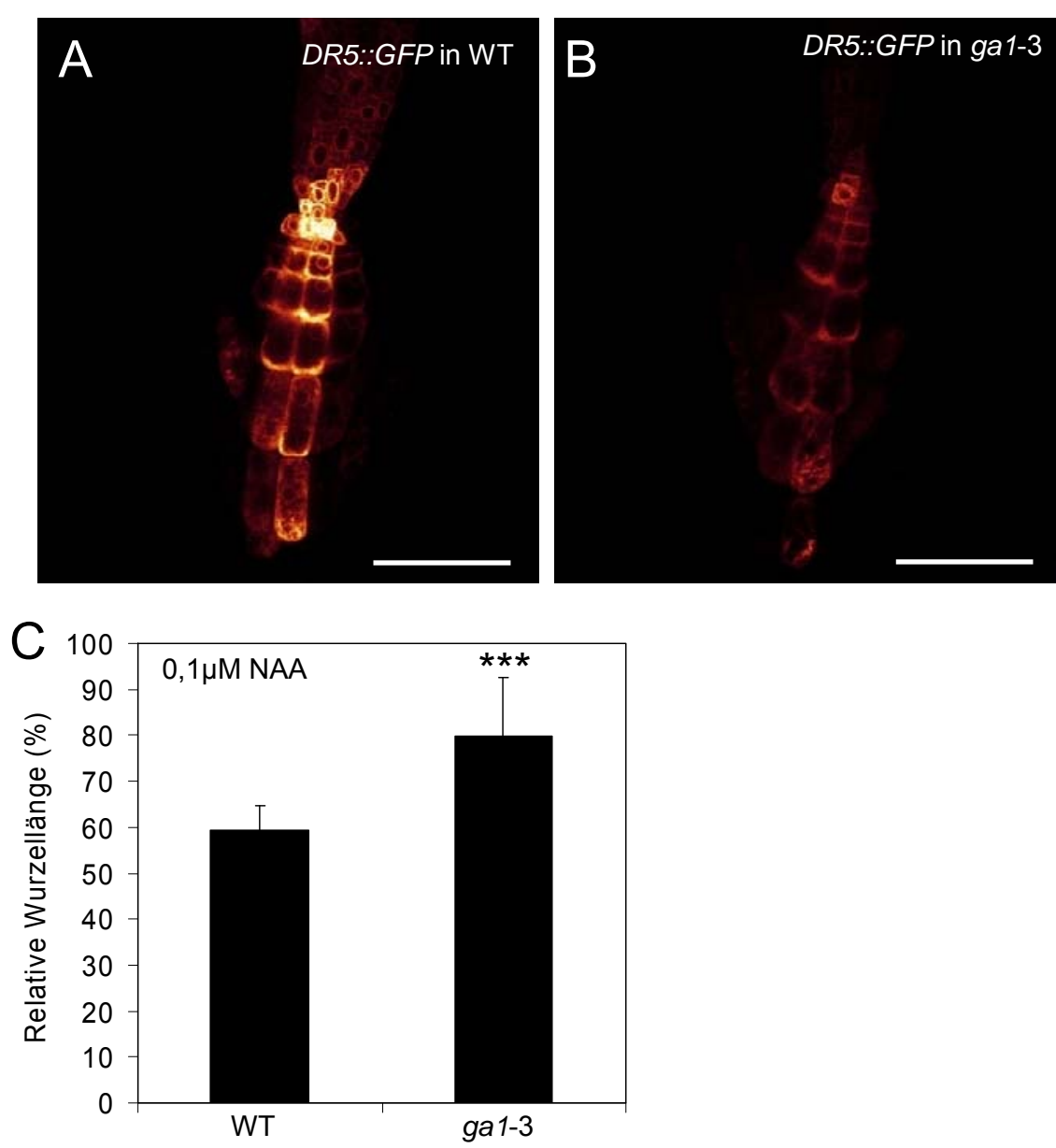

Abb. 10: Auxin Verteilung in der Wurzelspitze und Effekt von exogen appliziertem Auxin auf das Wurzelwachstum in der GA-Biosynthese Mutante ga1-3. (A) DR5::GFP-Signal in der Wurzelspitze. (B) DR5::GFP-Signal im gal-3 Hintergrund. (C) Auxinvermittelte Inhibierung des Wurzelwachstums durch exogene Applikation von NAA. Maßstab in A und B entspricht $50 \mu \mathrm{m}$. Die in A und B gezeigten Bilder sind repräsentativ für 3 Experimente $(n=8)$. Die Daten in C repräsentieren Mittelwerte und SD von einem repräsentativen Experiment mit jeweils 8 biologischen Wiederholungen. Sternchen symbolisieren einen signifikanten Unterschied zwischen der WT-Kontrolle und der Mutante entsprechend des student's $t$-tests $(* * *: \mathrm{p} \leq 0,001)$. 


\section{Material und Methoden (zusätzliche Ergebnisse)}

\subsection{Wachstumsbedingungen und pharmakologische Behandlungen}

Für alle Experimente erfolgte die Anzucht der Pflanzen unter sterilen Bedingungen. Zur Oberflächensterilisation wurden die Samen für 5 min mit $70 \%$ Ethanol und 0,05\% Tween behandelt und anschließend unter der Sterilbank getrocknet. Die sterilen Samen wurden auf $1 / 2$ MS-Medium als Festmedium (1/2 Murashige \& Skoog Medium, 0,05 \% (w/v) MES, $1 \%$ (w/v) Saccharose, 1,5 \% (w/v) Plant Agar (Duchefa), pH 5,7 mit $1 \mathrm{M}$ $\mathrm{KOH}$ ) in rechteckigen Petrischalen ausgelegt und für $24 \mathrm{~h}$ bei $4{ }^{\circ} \mathrm{C}$ vernalisiert, bevor sie unter Langtagregime (16 h Belichtungszeit, 120 Photonen $\mu \mathrm{mol} \mathrm{m} \mathrm{m}^{-2} \mathrm{~s}^{-2}$ Licht, $22{ }^{\circ} \mathrm{C}$ ) vertikal kultiviert wurden.

Hormone, Inhibitoren und andere Chemikalien wurden wie in Abschnitt 9.4 beschrieben angesetzt und verwendet. Keimlinge wurden vor den Analysen für $3 \mathrm{~h}$ mit $50 \mu \mathrm{M}$ GA behandelt oder für $3 \mathrm{~d}$ auf Festmedium $10 \mu \mathrm{M}$ Uniconazol kultiviert. Um den Auxintransport zu inhibieren, wurden Pflanzen $1 \mathrm{~h}$ vor dem Versuch auf frisch hergestellte $10 \mu \mathrm{M}$ NPA-Platten transferiert und zum besseren Kontakt mit Wasser benetzt.

Samen der GA-Biosynthese Mutante gal-3 wurden durch Quellen $\left(7 \mathrm{~d}, 4{ }^{\circ} \mathrm{C}\right)$ in einer sterilen, wässrigen $50 \mu \mathrm{M}$ GA-Lösung zur Keimung gebracht. Kreuzungen mit gal-3 Pflanzen wurden selektiert, indem Samen der $\mathrm{F}_{2}$-Generation erst auf $1 / 2 \mathrm{MS}$ Festmedium angezogen, die gekeimten Samen verworfen und die ungekeimten Samen dann mit $50 \mu \mathrm{M}$ GA zur Keimung gebracht wurden. Die aufgrund der GA-Behandlung gekeimten Samen konnten in Erde transferiert werden und die nächste Generation auf Homozygotie überprüft werden.

\subsection{RNA Isolation, cDNA Synthese und quantitative RT-PCR}

Aus $50 \mathrm{mg}$ Wurzelmaterial wurde nach Anleitung des Herstellers (innuPREP Plant RNA, Analytik Jena) Gesamt-RNA extrahiert und ein DNAse Verdau mit turboDNAfree (Ambion) angeschlossen. Die cDNA Synthese wurde mit 1,5 $\mu \mathrm{g}$ RNA und 20 pmol oligo(dT) (18 dT) Oligonukleotiden durchgeführt (RevertAid ${ }^{\mathrm{TM}}$ H Minus First Strand 
cDNASynthesis-Kit, Fermentas). Zur Amplifikation und Quantifikation der cDNA wurde das iClycler System (Biorad) verwendet. Zielgene wurden mittels genspezifischer Quantitect (Qiagen) Oligonukleotide amplifiziert. Als Referenzgen zur Normalisierung diente UBQ5 (10.2) (Kesarwani et al., 2007; Zander et al., 2010). Das Reaktionsgemisch zur Amplifikation beinhaltete $1 \times \mathrm{NH}_{4}$ Reaktionspuffer (Bioline), 2 $\mathrm{mM} \mathrm{MgCl}_{2}, 100 \mu \mathrm{M}$ dNTPs, $0.4 \mu \mathrm{M}$ der Oligonukleotide, 0.25 Einheiten BIOTaq DNA-Polymerase (Bioline), $10 \mathrm{nM}$ Fluorescein (Bio-Rad), 1:100000 verdünntes SYBR Green I (Cambrex), $1 \mu \mathrm{L}$ einer 1:10 Verdünnung der cDNA als Matrize. Mit destilliertem Wasser wurde das Reaktionsgemisch auf ein Gesamtvolumen von $25 \mu \mathrm{L}$ gebracht. Das PCR-Programm zur Amplifikation bestand aus einem initialen $90 \mathrm{~s}$ Denaturierungsschritt bei $95^{\circ} \mathrm{C}$, gefolgt von 40 Zyklen von $20 \mathrm{~s}$ bei $95^{\circ} \mathrm{C}, 20 \mathrm{~s}$ bei $55^{\circ} \mathrm{C}$, und $40 \mathrm{~s}$ bei $72{ }^{\circ} \mathrm{C}$. Zur Fehlerminimierung wurden drei technische sowie drei biologische Replikate verwendet und die Expressionsänderungen nach der $2^{-\Delta \Delta \mathrm{CT}}$ Methode berechnet (Livak und Schmittgen, 2001).

\subsection{Quantifizierung des akropetalen Auxintransports in der Wurzel}

Acht Tage alte Pflanzen, vertikal unter Langtagbedingungen auf $1 / 2$ MS gewachsen, wurden für den Auxintransport-Versuch verwendet. Der akropetale Auxintransport wurde nach einem modifizierten Protokoll von Rashotte et al. (2000) durchgeführt. Dafür wurde warme $1,5 \%$ (w/v) Agarose mit $200 \mathrm{nM} 3-\left[5(\mathrm{n})-{ }^{3} \mathrm{H}\right] \mathrm{IAA}$ (26 Ci/mmol; Amersham), $10 \mu \mathrm{M}$,kaltem“ IAA und DMSO mit einer Endkonzentration von 0,2 \% (v/v) gemischt. Nach dem Abkühlen in dem Deckel eines Szintillationsgefäßes wurden mit einer Pasteurpipette kleine Agraosezylinder ausgestochen und auf den Übergang von Wurzel zu Spross platziert. Die vertikal orientierten Platten wurden bei $22{ }^{\circ} \mathrm{C}$ für $18 \mathrm{~h}$ in der Dunkelheit inkubiert, um die Degradation des Auxins durch Licht zu vermindern. Nach den $18 \mathrm{~h}$ wurde das untere Wurzelsegment mit einem Abstand von $1 \mathrm{~cm}$ zur $\left[{ }^{3} \mathrm{H}\right]$-Auxinquelle geerntet und in eine Mischung aus $10 \mathrm{~mL}$ Szintillationsflüssigkeit (Lumasafe plus, Luma-LSA B.V, Groningen, Niederlande) und $1 \mathrm{~mL} \mathrm{H}_{2} \mathrm{O}$ gegeben. Die Probe wurde dann in einem Szintillationszähler (Tri-Carb 2800TR, Perkin Elmer, Waltham, MA, USA) für 10 min vermessen. Die Experimente wurden dreimal mit jeweils 8 biologischen Replikaten wiederholt. 


\subsection{Mikroskopie}

Die Mikroskopierarbeiten wurden mit einem konfokalen Laser-Raster-Mikroskop der Firma Leica, Typ DM 6000, TCS SP5 AOBS an 8 Tage alten Pflanzen durchgeführt. Die Wurzeln wurden in einer $3 \%$ Glyzerinlösung betrachtet. Fluoreszenzintensitäten wurden mit Hilfe des Leica Quantifizierungsmoduls der LAS AF (2.1.0) Software ausgewertet. Dafür wurden die Grauwerte jeweils in der gleichen Bezugsfläche in jedem Bild bestimmt. Die Experimente wurden dreimal mit jeweils 8 biologischen Replikaten wiederholt.

\subsection{Statistische Auswertung}

Die Signifikanz mittels student's $t$-Test der einzelnen Experimente wurde mit Hilfe eines frei verfügbaren Internetprogramms bestimmt (http:/graphpad.com/quickcalcs/ index.cfm). 


\section{Zusammenfassung der zusätzlichen Ergebnisse}

Die im Manuskript „Gibberellin Regulates Root Gravitropism via Modulation of PIN Stability“ gezeigten Daten demonstrieren einen Einfluss von GA auf die PIN Stabilität während der gravitropen Krümmungsreaktion der Wurzel von A. thaliana. In den zusätzlichen Experimenten sollte der Zusammenhang zwischen dem positiven Einfluss von GA auf den PIN-Proteingehalt und einem möglichen Einfluss auf den Auxintransport bzw. die Auxinverteilung in der Wurzel untersucht werden. Dafür wurde in mit pharmakologischen Agenzien behandelten oder mutierten Pflanzenlinien mit Hilfe tritiierten Auxins der polare Auxintransport quantifiziert. Interessanterweise führte die Applikation exogenen GAs zu einem verringerten Auxintransport, während durch Uniconazolbehandlung verringerte endogene GA-Gehalte verstärkten Auxintransport zur Folge hatten. Diese durch pharmakologische Behandlungen erhobenen Daten konnten in einem genetischen Ansatz bestätigt werden, in dem entweder die pentupleMutante mit konstitutiv angeschalteter GA-Signaltransduktion, oder die gal-3-Mutante mit sehr geringen endogenen GA-Gehalten, verwendet wurde. Ein möglicher Grund für den Widerspruch von geringerem Auxintransport trotz stabilisierter PIN-Proteine könnte das durch GA erhöhte Recycling von „alten“ bzw. nicht mehr funktionalen PINProteinen sein. Es ist technisch bisher nicht möglich die Funktionalität der GAstabilisierten PIN-Proteine in vivo zu überprüfen. Experimente mit Dexamethasoninduzierbaren PIN2-GFP Linien deuten darauf hin, dass durch GA-Behandlung an der Plasmamembran stabilisierte PIN-Proteine die Insertion von de novo synthetisierten PIN-Proteinen verhindern. Zusätzlich zum Auxintransport wurde die Auxinverteilung bei veränderten GA-Gehalten in der Wurzel untersucht. Exogene Applikation von GA führte zu einem verstärkten $D R 5: \because G F P$-Signal in der Wurzelspitze. Die gemeinsame Gabe von GA und Auxin führte zu einer synergistischen Wirkung auf den DR5Promotor. Das verstärkte $D R 5:: G F P$-Signal lässt auf erhöhte Auxingehalte in der Wurzel schließen. Bestärken ließ sich diese Hypothese durch eine erhöhte Sensitivität GA-behandelter Pflanzen auf exogenes Auxin. Komplementär dazu zeigte die gal-3Mutante, in der die GA-Biosynthese genetisch unterbrochen ist, ein schwächeres DR5::GFP-Signal und war weniger sensitiv auf exogen appliziertes Auxin.

Zusammenfassend zeigen die Ergebnisse, dass GA den Auxintransport und den daraus resultierenden Auxingehalt in der Wurzel moduliert. 


\section{Diskussion des Manuskripts und der zusätzlichen Ergebnisse}

Komplexe Wachstums- und Entwicklungsprozesse der Pflanzen werden von verschiedenen Phytohormonen gesteuert, die teilweise überlappende Funktionen haben (Jaillais und Chory, 2010). Die Wirkung der Phytohormone ist dabei nicht isoliert zu sehen, sondern Phytohormone zeigen oft eine Vernetzung von Signaltransduktionskaskaden, um bestimmte physiologische Reaktionen zu vermitteln. Zu Beginn dieser Arbeit war bereits bekannt, dass Auxin in A. thaliana die Expression der GABiosynthesegene GA20ox1 und GA20ox2 induziert (Frigerio et al., 2006). In vorangegangenen Arbeiten wurde am Beispiel der gravitropen Krümmungsreaktion demonstriert, dass GA zumindest in oberirdischen Organen monokotyler Pflanzen ähnlich wie Auxin eine durch Gravistimulation induzierte asymmetrische Verteilung zeigt (Cui et al., 2005; Wolbang et al., 2007). Bislang war eine mögliche mechanistische Vernetzung von Auxin und GA bei der gravitropen Krümmungsreaktion nicht untersucht worden. Sowohl Auxin als auch GA steuern das Streckungswachstum von Zellen, daher war eine Arbeitshypothese dieser Arbeit, dass asymmetrisch vorliegendes GA zur Kontrolle der gravitropen Krümmungsreaktion beiträgt. Ziel dieser Arbeit war es, diese Vernetzung von GA und Auxin auf der Ebene des Gravitropismus in Wurzeln von A. thaliana zu beschreiben.

In der folgenden Diskussion beziehen sich die Angaben zu „Figures“ (Fig.) auf das Manuskript und „Abbildungen“ (Abb.) auf das Kapitel „zusätzliche Ergebnisse“.

\subsection{Während der gravitropen Krümmungsreaktion beeinflusst asymmetrische GA-Verteilung die Etablierung des Auxingradienten}

Die gravitrope Krümmungsreaktion von A. thaliana ist durch zeitlich begrenztes, asymmetrisches Wachstum gekennzeichnet, das mit einer asymmetrischen Auxinverteilung einhergeht. Es sollte untersucht werden, ob der Einfluss von Auxin auf die Transkription der GA-Biosynthesegene GA20ox1 und GA20ox2 (Frigerio et al., 2006) und den damit verbundenen GA-Gehalt in der Pflanze im Gravitropismus der Wurzel ein Rolle spielt. Die hier erarbeiteten Daten weisen darauf hin, dass während der gravitropen Krümmungsreaktion der Wurzel zuerst das auxinresponsive Gen GH3.1 
verstärkt exprimiert wird und danach zeitversetzt das GA-Biosynthesegen GA20oxl (Supplementary Fig. 4). Diese Beobachtung deutet darauf hin, dass es in der Wurzel nach gravitroper Induktion zuerst zu einem Anstieg der Auxingehalte und hierdurch ausgelöst zur Zunahme der GA-Konzentration kommt. Daten von monokotylen Pflanzen (Cui et al., 2005; Wolbang et al., 2007) und hier präsentierte Ergebnisse (Fig. 3) zeigen, dass es in gravistimulierten Organen zusätzlich zur Erhöhung der GAGehalte $\mathrm{zu}$ einer asymmetrischen Verteilung von GA kommt. GA hat wiederum direkten Einfluss auf die PIN-Proteingehalte in der Wurzel und kann somit zur schon beschriebenen asymmetrischen PIN2-Verteilung zwischen Ober- und Unterseite der Wurzel nach gravitroper Reizwahrnehmung beitragen. PIN2 wird auf der Oberseite der Wurzel verstärkt abgebaut (Kleine-Vehn et al., 2008a) und die zur Auxinakkumulation zeitversetzte GA-Akkumulation auf der Unterseite könnte zu einer verstärkten, lang anhaltenden PIN2 Stabilisierung führen. Dies könnte die anfänglich initiierte differentielle Degradation unterstützen, indem die auf der Unterseite lokalisierten PIN2Proteine durch die asymmetrische, auxininduzierte GA-Akkumulation stabilisiert werden. Die GA-induzierte PIN2 Stabilisierung äußerte sich in hier gezeigten Experimenten in einer symmetrischen, lateralen Auxinverteilung in GA-behandelten, gavistimulierten Wurzeln, die mit der Auxin-Reporterlinie DR5::GFP visualisiert wurde (Fig. 2). Auffällig war, dass die symmetrische, laterale Auxinverteilung nur nach GA-Gabe bei gleichzeitiger Gravistimulation zu beobachten war und nicht bei alleiniger GA-Gabe (Daten nicht gezeigt). Dies lässt auf gravi-induzierte Auxinsynthese in der Wurzelspitze schließen. Ottenschlager et al. (2003) demonstrierten, dass in Pflanzen, in denen der Auxintransport durch NPA gehemmt war, nur nach Gravistimulation ein gegenüber vertikal gewachsenen, NPA-behandelten Kontrollpflanzen verstärktes, ausgeweitetes DR5-Signal in der Wurzelspitze beobachtet wurde. Demnach würde das nach Gravistimulation synthetisierte Auxin in der Wurzelspitze akkumulieren. Die beobachtete Inhibierung des Gravitropismus nach GA-Behandlung (Fig. 1) ist somit wahrscheinlich auf die GA-induzierte PIN2 Stabilisierung zurückzuführen, die als Folge den Aufbau einer Auxinasymmetrie verhindert. Entsprechend führten niedrigere GAGehalte durch Fehlen eines GA-Biosynthesegens in der gal-3-Mutante oder hervorgerufen durch Uniconazolgabe zur erhöhten Degradation der PIN2-Proteine (Fig. 7 A-D) und die differentielle Degradation, die zur Etablierung des Auxingradienten nötig ist, wäre demnach erschwert. Dies könnte den agravitropen Phänotyp der pin2 Insertionslinie nachahmen, in der durch Fehlen der lateral verteilten 
PIN2-Proteine der Auxinfluss nicht mehr effektiv umverteilt werden kann (Chen et al., 1998; Luschnig et al., 1998; Müller et al., 1998; Utsuno et al., 1998).

Nicht nur für höhere Gefäßpflanzen wird vermutet, dass GA eine Rolle im Gravitropismus spielt. Für Bryophyten wie Physcomitrella patens konnte auch ein Effekt von GA auf die Protonemataentwicklung und deren gravitrope Ausrichtung gezeigt werden (Chaban et al., 1999; Vandenbussche et al., 2007). Interessant wäre zu klären, ob das P. patens Homolog der ER-lokalisierten Arabidopsis PIN-Proteine, PpPINA, in ähnlicher Weise auf GA reagiert wie AtPINs und vor allem wie der GAReiz in $P$. patens wahrgenommen und verarbeitet werden kann, obwohl die GASignaltransduktionshomologe in $P$. patens teilweise nicht funktional sind (Vandenbussche et al., 2007).

\subsection{GA moduliert die Balance zwischen PIN-Abbau und PIN-Recycling}

Auxinefflux erfolgt durch polar verteilte PIN-Proteine, die als Schlüsselregulatoren an einer Vielzahl auxinvermittelter Entwicklungsprozesse beteiligt sind (Friml et al., 2003). Die Menge an PIN-Proteinen an der Plasmamembran kann über de novo Synthese, Recycling, Transcytose oder Degradation reguliert werden und demnach sehr dynamisch auf Stimuli reagieren (Delker et al., 2008; Kleine-Vehn et al., 2008a; Grunewald und Friml, 2010; Kleine-Vehn et al., 2010). Ein Ziel dieser Arbeit war es, Ursachen und Mechanismen der GA-vermittelten Erhöhung der PIN-Gehalte zu beschreiben. Die PIN-Transkription in der Wurzel konnte durch GA-Gabe nicht verändert werden (Supplementary Fig. 7). Übereinstimmend konnte gezeigt werden, dass in einer Dexamethason induzierbaren PIN2-GFP Linie das GFP-Signal nach kurzeitiger Induktion und gleichzeitiger GA-Gabe verglichen zu der Kontrolle länger erhalten blieb (Fig. 5). Daher kann man davon ausgehen, dass der positive Effekt von GA auf den PIN-Proteingehalt (Fig. 4 A und B; Fig. 9 A und B) nicht transkriptionell, sondern durch Beeinflussung der Proteinstabilität reguliert ist.

Beginnend an der Plasmamembran werden PIN2-Proteine kontinuierlich internalisiert und über Endosomen, die als Sortierungsstation dienen, entweder über den GNOM-abhängigen Weg zurück an die Plasmamembran oder zum prävakuolären Kompartiment (PVC) transportiert (Abb. 3). Das PVC dient wiederum als Sortierungsstation und bestimmt die Balance zwischen Abbau in der lytischen Vakuole 
und dem Recycling zurück an die Plasmamembran über den Retromerkomplex SNX1/VPS29 (Jaillais et al., 2006; Jaillais et al., 2007). Der dynamische PINEndomembranfluss, der mutmaßlich an dem positiven Effekt von GA beteiligt ist, kann über Inhibitoren, Mutanten und spezifische Markierungen analysiert werden (Abb. 3). Im Rahmen der vorliegenden Arbeit war ein experimentelles Ziel zu zeigen, welcher Schritt des Endomembranflusses durch GA beeinflusst wird. Der endozytotische Schritt von der Plasmamembran zu den Endosomen wird mit Hilfe des Indikators FM4-64 analysiert. Die Aufnahme des Farbstoffes war nach GA-Gabe nicht verändert (Supplementary Fig. 10). Nach Gabe von Wortmannin, das die Funktion der PVC stört und zur Akkumulation von PIN2 im PVC führt, konnte ebenfalls kein Unterschied in der Signalstärke der WM-induzierten PVCs festgestellt werden (Supplementary Fig. 11). Andererseits führte GA-Gabe zu verstärkter PIN2 Akkumulation in BFAinduzierten Endosomen und inhibierte die Degradation in der lytischen Vakuole (Fig. 68). Dies zusammen lässt auf ein gefördertes Recycling über den Retromerkomplex von dem PVC zu den Endosomen schließen (Abb. 11). Zusätzlich war in der snx1-Mutante der positive Effekt von GA auf die PIN-Stabilität aufgehoben (Fig. 9). SNX1 ist mit an der Regulation der gravitropen Krümmungsreaktion beteiligt und snxl-Mutanten zeigen einen agravitropen Phänotyp (Jaillais et al., 2006). Voraussetzung für die gravitrope Krümmungsreaktion sind zeitlich aufeinander folgende Degradations- und Aufbauvorgänge von PIN-Proteinen, die Asymmetrie erst einleiten und dann wieder aufheben. Für den netto PIN2-Proteingehalt während des Gravitropismus wurden zwei zeitlich voneinander getrennte Zunahmen gezeigt, wobei die später erfolgende SNX1abhängig ist (Kleine-Vehn et al., 2008a). Demnach ist SNX1 wahrscheinlich für die verstärkte Rückgewinnung von PIN2 vom PVC nötig bei zeitlich ausgedehnten Krümmungsreaktionen der Wurzel (Kleine-Vehn et al., 2008a). Die zur Auxinakkumulation zeitversetzte, asymmetrische Akkumulation von GA nach gravitroper Stimulation könnte diesen SNX1-abhängigen, zeitversetzten regulatorischen Schritt im Gravitropismus beeinflussen und dementsprechend die anfänglich initiierte differentielle Verteilung von PIN2 über Stabilisierung der PIN2-Proteine auf der Wurzelunterseite aufrechterhalten. Die Ergebnisse der Charakterisierung der Doppelmutante 35S::PIN1 x gai 17 bestätigen den Stabilisierungseffekt von GA auf PIN-Proteine (Fig. 10). Überexpression von PIN1 unter einem 35S-Promotor führten zu ektopischer, basaler Lokalisierung von PIN1 in Wurzelepidermiszellen (Fig. 10 D). Als Folge war in den Wurzelepidermiszellen PIN1 den PIN2-Proteinen gegenüberliegend 
angeordnet. Dieses Phänomen ist wahrscheinlich für den dramatisch agravitropen Phänotyp von 35S::PIN1 Pflanzen verantwortlich (Benkova et al., 2003; Wisniewska et al., 2006). Die dominant negative Form von GAI gaid17 unterbricht die GASignaltransduktion, wodurch die PIN-Degradation gesteigert ist. Die erhöhte Degradation scheint insbesonders das ektopisch exprimierte PIN zu beeinflussen und als Folge des PIN-Abbaus ist die Wuchsrichtung der Wurzel entlang des Gravitationsvektors wieder hergestellt (Fig. 10 A). Eine abgeschwächte Suppression des Phänotyps wurde durch Uniconazolgabe erreicht, die durch Absenken des niedrigeren GA-Gehalts ebenfalls die Degradationsrate von PIN-Proteinen erhöhte (Fig. 10 C).

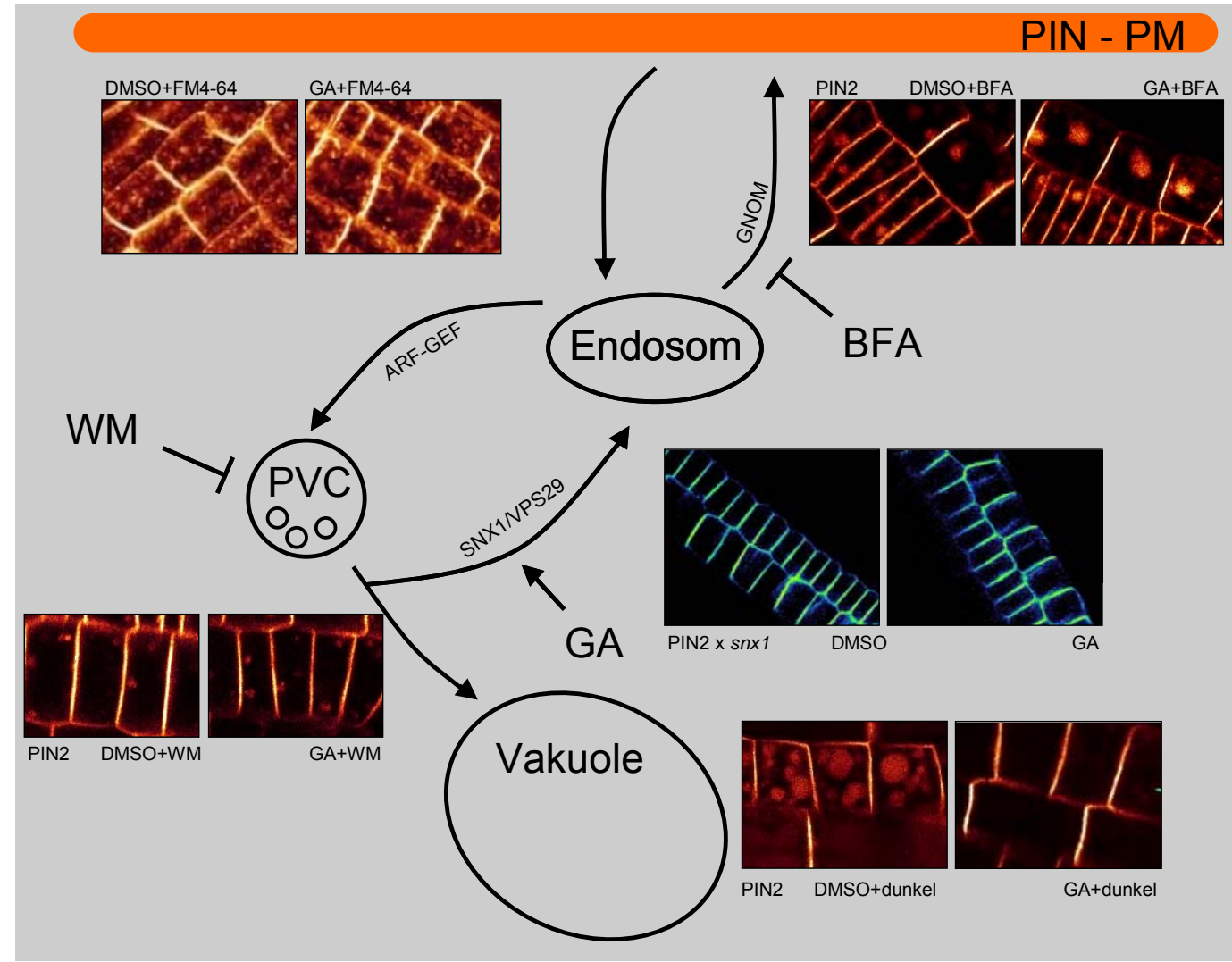

Abb. 11: Arbeitshypothese zur Erklärung des Effekts von GA auf das retrograde Recycling von PIN2 und dessen Endomembranfluss. Beginnend an der Plasmamembran (PM) werden PIN-Proteine kontinuierlich internalisiert und über Endosomen, die als Sortierungsstation dienen, entweder durch das GNOM-abhängige Cycling zurück an die Plasmamembranoder zum PVC transportiert. Hier werden sie neu sortiert und entweder mit Hilfe des Retromerkomplexes SNX1/VPS29 zurück an die Plasmamembran gebracht oder es erfolgt der Transport zur Vakuole und Abbau. Die Analyse des PIN-Recycling ist mit Hilfe spezifischer Inhibitoren oder Mutanten, die in den Endomembranfluss eingreifen bzw. darin gestört sind, möglich. WM stört die Funktion des PVC und führt zur Akkumulation von PIN2-Proteinen in diesen. BFA inhibiert unter anderem das GNOM-abhängige Cycling und führt zur Akkumulation in BFAKompartimenten, die Endosomen äquivalent sind. GA hat keinen Einfluss auf das PIN2-Signal in WM-Kompartimenten und die Internalisation des Endozytoseindikators FM4-64. PIN2 akkumuliert aber nach GA- und BFA-Behandlung verstärkt in BFA-Kompartimenten und die Degradation in der lytischen Vakuole ist inhibiert, was auf ein gefördertes Recycling vom PVC zu den Endosomen schließen lässt. Zusätzlich ist der GA-Effekt in der snx1-Mutante auf die PIN2-Stabilität nicht mehr nachweisbar und diese Beobachtung deutet darauf hin, dass GA die geförderte Stabilisierung über Retromer-vermitteltes Recycling reguliert und SNX1-abhängig ist. 


\subsection{GA und seine Wirkung auf den Auxintransport}

Apikale Spross- und Blattmeristeme sind Hauptsyntheseorte von Auxin, das als einziges pflanzliches Hormon nachweislich polar transportiert wird und somit in der Pflanze einen axialen Auxingradienten vom Spross zur Wurzel etabliert. Der vom Sprossapex kommende Auxinstrom kehrt sich in der Wurzelspitze wieder um und das Auxin wird von der Wurzelspitze ausgehend basipetal in Richtung Spross transportiert (Tanimoto, 2005). In [ $\left.{ }^{3} \mathrm{H}\right] \mathrm{IAA}$ Transportversuchen wurde gezeigt, dass erhöhte GA-Gehalte oder eine konstitutiv aktive GA-Signaltransduktion zu geringeren $\left[{ }^{3} \mathrm{H}\right] \mathrm{IAA}$ Transportraten führten und komplementär dazu geringere GA-Gehalte in der gal-3 Mutante, oder verursacht durch Uniconazolgabe den $\left[{ }^{3} \mathrm{H}\right] \mathrm{IAA}$ Transport verstärkten (Abb. 7). Auf den ersten Blick stehen diese Daten im Widerspruch zum im Manuskript gezeigten stabilisierenden Effekt von GA auf PIN-Proteine, bei dem GA die PIN-Konzentration an der Plasmamembran erhöht (Fig. 4 B), denn durch erhöhte PIN-Konzentration sollte der Auxintransport eher gefördert sein. Eine Begründung für den Widerspruch von verringertem Auxintransport trotz erhöhter PIN-Konzentration könnte eine veränderte Funktionalität der PIN-Proteine sein. Die Hypothese, dass durch erhöhte GA-Gehalte in der Pflanze verstärkt nicht mehr funktionale PIN-Proteine recycelt und statt zur Vakuole an die Plasmamembran transportiert werden, konnte durch den indirekten Nachweis GA-stabilisierter PIN-Proteine gestützt werden, welche die Lokalisierung bzw. Insertion de novo synthetisierter PIN-Proteine verhindern. Dafür wurden DEX-induzierbare PIN2-GFP Pflanzen mit GA vorbehandelt, um endogene PIN-Proteine wie PIN3, PIN4 und PIN7 in der Wurzelspitze zu stabilisieren, um dann zeitversetzt PIN2-GFP zu induzieren. Es zeigte sich eine signifikante Reduktion des ektopisch exprimierten PIN2GFP-Signals in GA-vorbehandelten Pflanzen in dem Bereich der natürlich vorkommenden PIN-Proteine (Abb. 8). Diese Beobachtungen weisen darauf hin, dass PIN-Proteine durch gesteigertes SNX1-abhängiges Recycling immer wieder zurück an die Plasmamembran transportiert werden, anstatt sie abzubauen. Daher könnten sie in ihrer Funktionalität anhand des erhöhten Alters eingeschränkt sein und ihre Transportaufgabe nicht mehr effektiv wahrnehmen. Eine weitere Erklärung für den GAinhibierten Auxintransport könnten PIN-Proteine aus der zweiten Unterklasse wie PIN5 sein, die ER-lokalisiert sind und die durch ihre Aktivität das zytosolisch verfügbare Auxin für den interzellularen Transport limitieren, der von Typ 2 PIN-Proteinen vermittelt wird (Mravec et al., 2009). Die Daten von Mravec et al. (2009) zeigten, dass 
bei Überexpression von PIN5 der Auxinexport gehemmt und konsequenterweise in der pin5-Mutante der Auxinexport gesteigert war. Es erscheint also denkbar, dass GA nicht nur Typ 1 PIN-Proteine stabilisiert, sondern auch Einfluss auf den Typ 2 PINProteingehalt hat und somit das Auxin für den polaren Transport limitiert. Es ist aber noch nicht bekannt, ob Typ 2 PIN-Proteine genauso über den Retromer-abhängigen Weg recycelt werden wie Typ 1 Proteine.

Veränderungen im Auxintransport spiegeln sich auch in der Auxinverteilung in der Wurzelspitze wieder, wie durch den DR5::GFP-Reporter visualisiert wurde (Abb. 9 und 10). Interessant ist, dass durch Inhibierung des Auxintransports durch NPA-Gabe oder in der pin4-Mutante das DR5::GFP-Signal in der Wurzelspitze verstärkt und ausgeweitet wird (Friml et al., 2002b), vergleichbar dem DR5::GFP-Signal in GAbehandelten Pflanzen (Abb. 9). Ein ähnlicher Effekt wurde für die A. thaliana pin2Mutante gezeigt, in der Auxin verglichen zur Kontrolle verstärkt in der lateralen Wurzelhaube akkumulierte (Sabatini et al., 1999; Ottenschlager et al., 2003). Würde der gesamte Auxintransport der Wurzel durch GA gehemmt werden, sollte Auxin, das im Wurzelmeristem synthetisiert wurde, in der Wurzelspitze akkumulieren und ein verstärktes DR5::GFP-Signal verursachen. Verblüffend ist, dass gleichzeitige Applikation von NPA und Auxin zu einer starken Akkumulation des DR5::GFP-Signals in der Wurzelspitze und der lateralen Wurzelhaube führen (Ottenschlager et al., 2003). Dieses Phänomen wurde bei gleichzeitiger Gabe von GA und NAA verifiziert (Abb. 9 C). Im Kontrast zu diesen Beobachtungen stehen Daten die aus Transportversuchen in oberirdischen Pflanzenorganen stammen und den positiven Effekt von GA auf den Auxintransport beschreiben (Jacobs und Case, 1965; Bjorklund et al., 2007). Vielleicht unterscheidet sich nicht nur Auxin in der Dosis-Wirkung-Beziehung zwischen Spross und Wurzel, sondern auch GA. Tanimoto et al. (1994) postulieren, dass die native Wirkung von GA wachstumsfördernd auf die Wurzel ist, jedoch reagiert die Wurzel deutlich sensitiver auf GA als das Hypokotyl. 


\subsection{GA wirkt über die Beeinflussung des Auxingehalts auf das Wurzelwachstum}

Eine Störung von Auxinhaushalt oder Auxinperzeption führt dazu, dass der Effekt exogen applizierten Auxins verstärkt oder abgeschwächt wird. Daher können Störungen der Auxinhomöostase z.B. über den Grad der Inhibierung der Wurzelelongation durch exogen appliziertes Auxin quantifiziert werden (Ruzicka et al., 2007; Delker et al., 2010). Keimlinge, die auf GA-versetztem Medium wuchsen, hatten leicht reduzierte Wurzellängen und gleichzeitige NAA- und GA-Gabe führte zu einer mehr als additiven Reduktion der Wurzelelongation. Der mehr als additive Effekt von GA und Auxin auf die Wurzelelongation wurde in einer vorangegangenen Veröffentlichung beschrieben (Desgagne-Penix und Sponsel, 2008), aber nicht in Bezug zum Auxingehalt in der Wurzelspitze und daraus resultierende Zellelongation gesetzt. Die GABiosynthesemutante gal-3 hat kürzere Wurzeln, weniger Meristemzellen und nicht vollständig elongierte Wurzelzellen (Achard et al., 2009; Ubeda-Tomas et al., 2009). Durch geringere Auxingehalte in der Wurzel, wie anhand der DR5::GFP-Expression bestimmt, ist die $A$. thaliana gal-3-Mutante weniger sensitiv gegenüber exogen appliziertem Auxin verglichen mit der Situation in Kontrollpflanzen (Abb. 10). In Versuchen zur Elongation von Protoplasten oder Pflanzenorganen wurde gezeigt, dass Auxin die Zellelongation und Zellteilung fördert (Rayle et al., 1970; Rayle und Cleland, 1992; Campanoni und Nick, 2005). Basierend auf den Ergebnissen dieser Arbeit ist eine mögliche Erklärung für den Wurzelphänotyp von gal-3, dass die verringerten GAGehalte eine Abnahme der Auxinkonzentration zur Folge haben und somit Zellteilung im Meristem und Zellelongation in der Streckungszone negativ beeinflussen. $\mathrm{Ob}$ die veränderten Auxingehalte durch den modulierten Auxintransport oder durch direkte oder indirekte Beeinflussung der Auxinbiosynthese verursacht werden, bleibt zu klären. In silico Analysen mit Hilfe eines frei verfügbaren Analyseprogramms (Geneinvestigator; https://www.genevestigator.com) der Auxinbiosynthesegene nach GA-Stimulus oder in der gal-3 Mutante zeigten keine auffälligen Veränderungen (Daten nicht gezeigt). Damit könnte teilweise der Wurzelphänotyp von gal-3 Mutanten über den GA-modulierten Auxintransport erklären werden. 


\subsection{Zukünftige Arbeiten}

Die in dieser Arbeit präsentierten Daten weisen eine Vernetzung der beiden Wachstumshormone Auxin und Gibberellin während der gravitropen Krümmungsreaktion der Wurzel nach. Der vorgeschlagene Mechanismus der Vernetzung beinhaltet ein GA-reguliertes retrogrades Recycling von PIN-Proteinen über den SNX1abhängigen Weg im PIN-Endomembranfluss. Demnach kann GA aktiv die PINKonzentration an der Plasmamembran regulieren. Zu klären wäre, wie genau GA das SNX1-abhängige Recycling beeinflusst, bzw. wo der molekulare Ansatzpunkt von GA liegt. Desweiteren ist ein zukünftiges Ziel zu untersuchen, ob Typ 2 PIN-Proteine wie PIN5 auch durch GA beeinflussbar sind und ob sie über das SNX1-abhängige Recycling reguliert werden können, um die teilweise Inkongruenz zwischen verringerten Transportraten und erhöhter PIN-Konzentration endgültig zu klären. 


\section{Literaturverzeichnis}

Abas, L., Benjamins, R., Malenica, N., Paciorek, T., Wirniewska, J., MoulinierAnzola, J.C., Sieberer, T., Friml, J., and Luschnig, C. (2006). Intracellular trafficking and proteolysis of the Arabidopsis auxin-efflux facilitator PIN2 are involved in root gravitropism. Nature Cell Biology 8, 249-256.

Achard, P., Gusti, A., Cheminant, S., Alioua, M., Dhondt, S., Coppens, F., Beemster, G.T.S., and Genschik, P. (2009). Gibberellin Signaling Controls Cell Proliferation Rate in Arabidopsis. Curr. Biol. 19, 1188-1193.

Banbury, A.N., Oakley, J.D., Sessions, R.B., and Banting, G. (2003). Tyrphostin A23 inhibits internalization of the transferrin receptor by perturbing the interaction between tyrosine motifs and the medium chain subunit of the AP-2 adaptor complex. J. Biol. Chem. 278, 12022-12028.

Bartel, B. (1997). Auxin biosynthesis. Annu. Rev. Plant Physiol. Plant Molec. Biol. 48, 49-64.

Bartel, B., and Fink, G.R. (1994). Differential Regulation of an Auxin-Producing Nitrilase Gene Family in Arabidopsis thaliana. Proceedings of the National Academy of Sciences of the United States of America 91, 6649-6653.

Benkova, E., Michniewicz, M., Sauer, M., Teichmann, T., Seifertova, D., Jurgens, G., and Friml, J. (2003). Local, efflux-dependent auxin gradients as a common module for plant organ formation. Cell 115, 591-602.

Bennett, M.J., Marchant, A., Green, H.G., May, S.T., Ward, S.P., Millner, P.A., Walker, A.R., Schulz, B., and Feldmann, K.A. (1996). Arabidopsis AUX1 gene: A permease-like regulator of root gravitropism. Science 273, 948-950.

Bjorklund, S., Antti, H., Uddestrand, I., Moritz, T., and Sundberg, B. (2007). Cross-talk between gibberellin and auxin in development of Populus wood: gibberellin stimulates polar auxin transport and has a common transcriptome with auxin. Plant J. 52, 499-511.

Blakeslee, J.J., Bandyopadhyay, A., Lee, O.R., Mravec, J., Titapiwatanakun, B., Sauer, M., Makam, S.N., Cheng, Y., Bouchard, R., Adamec, J., Geisler, M., Nagashima, A., Sakai, T., Martinoia, E., Friml, J., Peer, W.A., and Murphy, A.S. (2007). Interactions among PIN-FORMED and P-glycoprotein auxin transporters in Arabidopsis. Plant Cell 19, 131-147.

Bolle, C. (2004). The role of GRAS proteins in plant signal transduction and development. Planta 218, 683-692.

Bonifacino, J.S., and Hurley, J.H. (2008). Retromer. Curr. Opin. Cell Biol. 20, 427 436.

Burden, R.S., Carter, G.A., Clark, T., Cooke, D.T., Croker, S.J., Deas, A.H.B., Hedden, P., James, C.S., and Lenton, J.R. (1987). Comparative Activity of the Enantiomers of Triadimenol and Paclobutrazole as Inhibitors of Fungal Growth and Plant Sterol and Gibberellin Biosynthesis Pesticide Science 21, 253-267.

Campanoni, P., and Nick, P. (2005). Auxin-dependent cell division and cell elongation. 1-Naphthaleneacetic acid and 2,4-dichlorophenoxyacetic acid activate different pathways. Plant Physiol. 137, 939-948.

Chaban, C.I., Kordyum, E.L., Demkiv, O.T., Khorkavtsiv, O.Y., and Khorkavtsiv, Y.D. (1999). The gravireaction of Ceratodon protonemata treated with gibberellic acid. Life Sciences: Microgravity Research Ii 24, 717-721.

Chen, R.J., Hilson, P., Sedbrook, J., Rosen, E., Caspar, T., and Masson, P.H. (1998). The Arabidopsis thaliana AGRAVITROPIC 1 gene encodes a 
component of the polar-auxin-transport efflux carrier. Proceedings of the National Academy of Sciences of the United States of America 95, 1511215117.

Cheng, H., Qin, L.J., Lee, S.C., Fu, X.D., Richards, D.E., Cao, D.N., Luo, D., Harberd, N.P., and Peng, J.R. (2004). Gibberellin regulates Arabidopsis floral development via suppression of DELLA protein function. Development 131, 1055-1064.

Cho, M., Lee, S.H., and Cho, H.T. (2007). P-glycoprotein4 displays auxin efflux transporter-like action in Arabidopsis root hair cells and tobacco cells. Plant Cell 19, 3930-3943.

Collings, D.A., Zsuppan, G., Allen, N.S., and Blancaflor, E.B. (2001). Demonstration of prominent actin filaments in the root columella. Planta 212, 392-403.

Cui, D.Y., Neill, S.J., Tang, Z.C., and Cai, W.M. (2005). Gibberellin-regulated XET is differentially induced by auxin in rice leaf sheath bases during gravitropic bending. Journal of Experimental Botany 56, 1327-1334.

Delker, C., Raschke, A., and Quint, M. (2008). Auxin dynamics: the dazzling complexity of a small molecule's message. Planta 227, 929-941.

Delker, C., Poschl, Y., Raschke, A., Ullrich, K., Ettingshausen, S., Hauptmann, V., Grosse, I., and Quint, M. (2010). Natural Variation of Transcriptional Auxin Response Networks in Arabidopsis thaliana. Plant Cell 22, 2184-2200.

Desgagne-Penix, I., and Sponsel, V.M. (2008). Expression of gibberellin 20-oxidase1 (AtGA20ox1) in Arabidopsis seedlings with altered auxin status is regulated at multiple levels. Journal of Experimental Botany 59, 2057-2070.

Dettmer, J., Hong-Hermesdorf, A., Stierhof, Y.D., and Schumacher, K. (2006). Vacuolar H+-ATPase activity is required for Endocytic and secretory trafficking in Arabidopsis. Plant Cell 18, 715-730.

Dhonukshe, P., Aniento, F., Hwang, I., Robinson, D.G., Mravec, J., Stierhof, Y.D., and Friml, J. (2007). Clathrin-mediated constitutive endocytosis of PIN auxin efflux carriers in Arabidopsis. Curr. Biol. 17, 520-527.

Dill, A., and Sun, T.P. (2001). Synergistic derepression of gibberellin signaling by removing RGA and GAI function in Arabidopsis thaliana. Genetics 159, 777785.

Donaldson, J.G., and Jackson, C.L. (2000). Regulators and effectors of the ARF GTPases. Curr. Opin. Cell Biol. 12, 475-482.

Emans, N., Zimmermann, S., and Fischer, R. (2002). Uptake of a fluorescent marker in plant cells is sensitive to brefeldin A and wortmannin. Plant Cell 14, 71-86.

Feng, S.H., Martinez, C., Gusmaroli, G., Wang, Y., Zhou, J.L., Wang, F., Chen, L.Y., Yu, L., Iglesias-Pedraz, J.M., Kircher, S., Schafer, E., Fu, X.D., Fan, L.M., and Deng, X.W. (2008). Coordinated regulation of Arabidopsis thaliana development by light and gibberellins. Nature 451, 475-U479.

Fischer, U., Ikeda, Y., Ljung, K., Serralbo, O., Singh, M., Heidstra, R., Palme, K., Scheres, B., and Grebe, M. (2006). Vectorial information for Arabidopsis planar polarity is mediated by combined AUX1, EIN2, and GNOM activity. Curr. Biol. 16, 2143-2149.

Frigerio, M., Alabadi, D., Perez-Gomez, J., Garcia-Carcel, L., Phillips, A.L., Hedden, P., and Blazquez, M.A. (2006). Transcriptional regulation of gibberellin metabolism genes by auxin signaling in arabidopsis. Plant Physiol. 142, 553-563.

Friml, J., Wisniewska, J., Benkova, E., Mendgen, K., and Palme, K. (2002a). Lateral relocation of auxin efflux regulator PIN3 mediates tropism in Arabidopsis. Nature 415, 806-809. 
Friml, J., Vieten, A., Sauer, M., Weijers, D., Schwarz, H., Hamann, T., Offringa, R., and Jurgens, G. (2003). Efflux-dependent auxin gradients establish the apical-basal axis of Arabidopsis. Nature 426, 147-153.

Friml, J., Benkova, E., Blilou, I., Wisniewska, J., Hamann, T., Ljung, K., Woody, S., Sandberg, G., Scheres, B., Jurgens, G., and Palme, K. (2002b). AtPIN4 mediates sink-driven auxin gradients and root patterning in Arabidopsis. Cell 108, 661-673.

Friml, J., Yang, X., Michniewicz, M., Weijers, D., Quint, A., Tietz, O., Benjamins, R., Ouwerkerk, P.B.F., Ljung, K., Sandberg, G., Hooykaas, P.J.J., Palme, K., and Offringa, R. (2004). A PINOID-dependent binary switch in apicalbasal PIN polar targeting directs auxin efflux. Science 306, 862-865.

Fu, X.D., and Harberd, N.P. (2003). Auxin promotes Arabidopsis root growth by modulating gibberellin response. Nature 421, 740-743.

Galweiler, L., Guan, C.H., Muller, A., Wisman, E., Mendgen, K., Yephremov, A., and Palme, K. (1998). Regulation of polar auxin transport by AtPIN1 in Arabidopsis vascular tissue. Science 282, 2226-2230.

Geisler, M., Blakeslee, J.J., Bouchard, R., Lee, O.R., Vincenzetti, V., Bandyopadhyay, A., Titapiwatanakun, B., Peer, W.A., Bailly, A., Richards, E.L., Ejenda, K.F.K., Smith, A.P., Baroux, C., Grossniklaus, U., Muller, A., Hrycyna, C.A., Dudler, R., Murphy, A.S., and Martinoia, E. (2005). Cellular efflux of auxin catalyzed by the Arabidopsis MDR/PGP transporter AtPGP1. Plant J. 44, 179-194.

Geldner, N., Friml, J., Stierhof, Y.D., Jurgens, G., and Palme, K. (2001). Auxin transport inhibitors block PIN1 cycling and vesicle traficking. Nature 413, 425428.

Geldner, N., Anders, N., Wolters, H., Keicher, J., Kornberger, W., Muller, P., Delbarre, A., Ueda, T., Nakano, A., and Jurgens, G. (2003). The Arabidopsis GNOM ARF-GEF mediates endosomal recycling, auxin transport, and auxindependent plant growth. Cell 112, 219-230.

Goldschmith, M.H.M. (1977). The Polar Transport of Auxin. Annual Review of Plant Physiology 28, 439-478.

Grebe, M., Friml, J., Swarup, R., Ljung, K., Sandberg, G., Terlou, M., Palme, K., Bennett, M.J., and Scheres, B. (2002). Cell polarity signaling in Arabidopsis involves a BFA-sensitive auxin influx pathway. Curr. Biol. 12, 329-334.

Grunewald, W., and Friml, J. (2010). The march of the PINs: developmental plasticity by dynamic polar targeting in plant cells. Embo Journal 29, 27002714.

Hartweck, L.M. (2008). Gibberellin signaling. Planta 229, 1-13.

Hejnowicz, Z., and Sievers, A. (1981). Regulation of the position of statoliths in Chara-rhizoids. Protoplasma 108, 117-137.

Hirano, K., Ueguchi-Tanaka, M., and Matsuoka, M. (2008). GID1-mediated gibberellin signaling in plants. Trends in Plant Science 13, 192-199.

Hirano, K., Nakajima, M., Asano, K., Nishiyama, T., Sakakibara, H., Kojima, M., Katoh, E., Xiang, H., Tanahashi, T., Hasebe, M., Banks, J.A., Ashikari, M., Kitano, H., Ueguchi-Tanaka, M., and Matsuoka, M. (2007). The GID1mediated gibberellin perception mechanism is conserved in the lycophyte Selaginella moellendorffii but not in the bryophyte Physcomitrella patens. Plant Cell 19, 3058-3079.

Hou, G.C., Mohamalawari, D.R., and Blancaflor, E.B. (2003). Enhanced gravitropism of roots with a disrupted cap actin cytoskeleton. Plant Physiol. 131, 1360-1373. 
Hou, G.C., Kramer, V.L., Wang, Y.S., Chen, R.J., Perbal, G., Gilroy, S., and Blancaflor, E.B. (2004). The promotion of gravitropism in Arabidopsis roots upon actin disruption is coupled with the extended alkalinization of the columella cytoplasm and a persistent lateral auxin gradient. Plant J. 39, 113-125.

Izumi, K., Kamiya, Y., Sakurai, A., Oshio, H., and Takahashi, N. (1985). Studies of sites of action of a new plant -growth retardent (E)-1-(4-CHLOROPHENYL)4,4-DIMETHYL-2-(1,2,4-TRIAZOL-1-YL)-1-PENTEN-3-OL (S-3307) and comparative effects of its stereoisomers in a cell-free system from Cucurbita maxima. Plant and Cell Physiology 26, 821-827.

Jacobs, W.P., and Case, D.B. (1965). Auxin transport Gibberellin and apical dominace Science 148, 1729-\&.

Jaillais, Y., and Chory, J. (2010). Unraveling the paradoxes of plant hormone signaling integration. Nature Structural \& Molecular Biology 17, 642-645.

Jaillais, Y., Fobis-Loisy, I., Miege, C., Rollin, C., and Gaude, T. (2006). AtSNX1 defines an endosome for auxin-carrier trafficking in Arabidopsis. Nature 443, 106-109.

Jaillais, Y., Santambrogio, M., Rozier, F., Fobis-Loisy, I., Miege, C., and Gaude, T. (2007). The retromer protein VPS29 links cell polarity and organ initiation in plants. Cell 130, 1057-1070.

Jelinkova, A., Malinska, K., Simon, S., Kleine-Vehn, J., Parezova, M., Pejchar, P., Kubes, M., Martinec, J., Friml, J., Zazimalova, E., and Petrasek, J. (2010). Probing plant membranes with FM dyes: tracking, dragging or blocking? Plant J. 61, 883-892.

Jurgens, G. (2004). Membrane trafficking in plants. Annu. Rev. Cell Dev. Biol. 20, 481-504.

Kesarwani, M., Yoo, J.M., and Dong, X.N. (2007). Genetic interactions of TGA transcription factors in the regulation of pathogenesis-related genes and disease resistance in Arabidopsis. Plant Physiol. 144, 336-346.

Kleine-Vehn, J., Dhonukshe, P., Swarup, R., Bennett, M., and Friml, J. (2006). Subcellular trafficking of the Arabidopsis auxin influx carrier AUX1 uses a novel pathway distinct from PIN1. Plant Cell 18, 3171-3181.

Kleine-Vehn, J., Ding, Z., Jones, A., Tasaka, M., Morita, M., and Friml, J. (2010). Gravity-induced PIN transcytosis for polarization of auxin fluxes in gravitysensing root cells. Proceedings of the National Academy of Sciences of the United States of America 21, 22344-22349.

Kleine-Vehn, J., Leitner, J., Zwiewka, M., Sauer, M., Abas, L., Luschnig, C., and Friml, J. (2008a). Differential degradation of PIN2 auxin efflux carrier by retromer-dependent vacuolar targeting. Proceedings of the National Academy of Sciences of the United States of America 105, 17812-17817.

Kleine-Vehn, J., Dhonukshe, P., Sauer, M., Brewer, P.B., Wisniewska, J., Paciorek, T., Benkova, E., and Friml, J. (2008b). ARF GEF-dependent transcytosis and polar delivery of PIN auxin carriers in Arabidopsis. Curr. Biol. 18, 526-531.

Kogl, F., Kostermans, D.G.F.R., Haagen-Smit, A.J., and Erxleben, H. (1934). Heteroauxin as metabolic product of lower plant organisms. Isolation from yeast. Z. physiol. Chem., 113-121.

Kurosawa, E. (1926). Experimental studies on the nature of the substance secreted by the "bakanae" fungus. Nat HistSoc Formosa 16, 213-227.

Lam, S.K., Siu, C.L., Hillmer, S., Jang, S., An, G.H., Robinson, D.G., and Jiang, L.W. (2007). Rice SCAMP1 defines clathrin-coated, trans-Golgi-located tubular-vesicular structures as an early endosome in tobacco BY-2 cells. Plant Cell 19, 296-319. 
Lee, S.C., Cheng, H., King, K.E., Wang, W.F., He, Y.W., Hussain, A., Lo, J., Harberd, N.P., and Peng, J.R. (2002). Gibberellin regulates Arabidopsis seed germination via RGL2, a GAI/RGA-like gene whose expression is up-regulated following imbibition. Genes Dev. 16, 646-658.

Livak, K.J., and Schmittgen, T.D. (2001). Analysis of relative gene expression data using real-time quantitative PCR and the 2(T)(-Delta Delta C) method. Methods 25, 402-408.

Long, J.C., Zhao, W., Rashotte, A.M., Muday, G.K., and Huber, S.C. (2002). Gravity-stimulated changes in auxin and invertase gene expression in maize pulvinal cells. Plant Physiol. 128, 591-602.

Luschnig, C., Gaxiola, R.A., Grisafi, P., and Fink, G.R. (1998). EIR1, a root-specific protein involved in auxin transport, is required for gravitropism in Arabidopsis thaliana. Genes Dev. 12, 2175-2187.

Michniewicz, M., Zago, M.K., Abas, L., Weijers, D., Schweighofer, A., Meskiene, I., Heisler, M.G., Ohno, C., Zhang, J., Huang, F., Schwab, R., Weigel, D., Meyerowitz, E.M., Luschnig, C., Offringa, R., and Friml, J. (2007). Antagonistic regulation of PIN phosphorylation by PP2A and PINOID directs auxin flux. Cell 130, 1044-1056.

Mitchum, M.G., Yamaguchi, S., Hanada, A., Kuwahara, A., Yoshioka, Y., Kato, T., Tabata, S., Kamiya, Y., and Sun, T.P. (2006). Distinct and overlapping roles of two gibberellin 3-oxidases in Arabidopsis development. Plant J. 45, 804818.

Morita, M.T. (2010). Directional Gravity Sensing in Gravitropism. Annual Review of Plant Biology, Vol 61 61, 705-720.

Mravec, J., Kubes, M., Bielach, A., Gaykova, V., Petrasek, J., Skupa, P., Chand, S., Benkova, E., Zazimalova, E., and Friml, J. (2008). Interaction of PIN and PGP transport mechanisms in auxin distribution-dependent development. Development 135, 3345-3354.

Mravec, J., Skupa, P., Bailly, A., Hoyerova, K., Krecek, P., Bielach, A., Petrasek, J., Zhang, J., Gaykova, V., Stierhof, Y.D., Dobrev, P.I., Schwarzerova, K., Rolcik, J., Seifertova, D., Luschnig, C., Benkova, E., Zazimalova, E., Geisler, M., and Friml, J. (2009). Subcellular homeostasis of phytohormone auxin is mediated by the ER-localized PIN5 transporter. Nature 459, 1136U1127.

Müller, A., Guan, C.H., Galweiler, L., Tanzler, P., Huijser, P., Marchant, A., Parry, G., Bennett, M., Wisman, E., and Palme, K. (1998). AtPIN2 defines a locus of Arabidopsis for root gravitropism control. Embo Journal 17, 6903-6911.

Nemhauser, J.L., Hong, F.X., and Chory, J. (2006). Different plant hormones regulate similar processes through largely nonoverlapping transcriptional responses. Cell 126, 467-475.

Oliviusson, P., Heinzerling, O., Hillmer, S., Hinz, G., Tse, Y.C., Jiang, L.W., and Robinson, D.G. (2006). Plant retromer, localized to the prevacuolar compartment and microvesicles in Arabidopsis, may interact with vacuolar sorting receptors. Plant Cell 18, 1239-1252.

Olszewski, N., Sun, T.P., and Gubler, F. (2002). Gibberellin signaling: Biosynthesis, catabolism, and response pathways. Plant Cell 14, S61-S80.

Ostin, A., Kowalyczk, M., Bhalerao, R.P., and Sandberg, G. (1998). Metabolism of indole-3-acetic acid in Arabidopsis. Plant Physiol. 118, 285-296.

Ottenschlager, I., Wolff, P., Wolverton, C., Bhalerao, R.P., Sandberg, G., Ishikawa, H., Evans, M., and Palme, K. (2003). Gravity-regulated differential 
auxin transport from columella to lateral root cap cells. Proceedings of the National Academy of Sciences of the United States of America 100, 2987-2991.

Paciorek, T., Zazimalova, E., Ruthardt, N., Petrasek, J., Stierhof, Y.D., KleineVehn, J., Morris, D.A., Emans, N., Jurgens, G., Geldner, N., and Friml, J. (2005). Auxin inhibits endocytosis and promotes its own efflux from cells. Nature 435, 1251-1256.

Peng, J.R., Carol, P., Richards, D.E., King, K.E., Cowling, R.J., Murphy, G.P., and Harberd, N.P. (1997). The Arabidopsis GAI gene defines a signaling pathway that negatively regulates gibberellin responses. Genes Dev. 11, 3194-3205.

Perera, I.Y., Heilmann, I., and Boss, W.F. (1999). Transient and sustained increases in inositol 1,4,5-hisphosphate precede the differential growth response in gravistimulated maize pulvini. Proceedings of the National Academy of Sciences of the United States of America 96, 5838-5843.

Petersson, S.V., Johansson, A.I., Kowalczyk, M., Makoveychuk, A., Wang, J.Y., Moritz, T., Grebe, M., Benfey, P.N., Sandberg, G., and Ljung, K. (2009). An Auxin Gradient and Maximum in the Arabidopsis Root Apex Shown by HighResolution Cell-Specific Analysis of IAA Distribution and Synthesis. Plant Cell 21, 1659-1668.

Petrasek, J., Mravec, J., Bouchard, R., Blakeslee, J.J., Abas, M., Seifertova, D., Wisniewska, J., Tadele, Z., Kubes, M., Covanova, M., Dhonukshe, P., Skupa, P., Benkova, E., Perry, L., Krecek, P., Lee, O.R., Fink, G.R., Geisler, M., Murphy, A.S., Luschnig, C., Zazimalova, E., and Friml, J. (2006). PIN proteins perform a rate-limiting function in cellular auxin efflux. Science 312, 914-918.

Phillips, A.L., Ward, D.A., Uknes, S., Appleford, N.E.J., Lange, T., Huttly, A.K., Gaskin, P., Graebe, J.E., and Hedden, P. (1995). Isolation and expression of 3 Gibberellin 20-Oxidase cDNA clones from Arabidopsis Plant Physiol. 108, 1049-1057.

Phinney, B., O. (1983). The history of gibberellins. (New York: Praeger Publishers ).

Rashotte, A.M., Brady, S.R., Reed, R.C., Ante, S.J., and Muday, G.K. (2000). Basipetal auxin transport is required for gravitropism in roots of arabidopsis. Plant Physiol. 122, 481-490.

Rayle, D.L., and Cleland, R.E. (1992). The acid growth theory of Auxin-induced cell elongation is alive and well. Plant Physiol. 99, 1271-1274.

Rayle, D.L., Evans, M.L., and Hertel, R. (1970). Action of Auxin on cell elongation. Proceedings of the National Academy of Sciences of the United States of America 65, 184-\&.

Robinson, D.G., Jiang, L.W., and Schumacher, K. (2008). The endosomal system of plants: Charting new and familiar territories. Plant Physiol. 147, 1482-1492.

Ross, J.J., O'Neill, D.P., Smith, J.J., Kerckhoffs, L.H.J., and Elliott, R.C. (2000). Evidence that auxin promotes gibberellin A(1) biosynthesis in pea. Plant J. 21, 547-552.

Rubery, P.H., and Sheldrake, A.R. (1974). Carrier-mediated Auxin Transport. Planta 118, 101-121.

Ruzicka, K., Ljung, K., Vanneste, S., Podhorska, R., Beeckman, T., Friml, J., and Benkova, E. (2007). Ethylene regulates root growth through effects on auxin biosynthesis and transport-dependent auxin distribution. Plant Cell 19, 21972212.

Sabatini, S., Beis, D., Wolkenfelt, H., Murfett, J., Guilfoyle, T., Malamy, J., Benfey, P., Leyser, O., Bechtold, N., Weisbeek, P., and Scheres, B. (1999). An auxin- 
dependent distal organizer of pattern and polarity in the Arabidopsis root. Cell 99, 463-472.

Seaman, M.N.J. (2005). Recycle your receptors with retromer. Trends Cell Biol. 15, 68-75.

Silverstone, A.L., Chang, C.W., Krol, E., and Sun, T.P. (1997). Developmental regulation of the gibberellin biosynthetic gene GA1 in Arabidopsis thaliana. Plant J. 12, 9-19.

Silverstone, A.L., Jung, H.S., Dill, A., Kawaide, H., Kamiya, Y., and Sun, T.P. (2001). Repressing a repressor: Gibberellin-induced rapid reduction of the RGA protein in Arabidopsis. Plant Cell 13, 1555-1565.

Sorefan, K., Girin, T., Liljegren, S.J., Ljung, K., Robles, P., Galvan-Ampudia, C.S., Offringa, R., Friml, J., Yanofsky, M.F., and Ostergaard, L. (2009). A regulated auxin minimum is required for seed dispersal in Arabidopsis. Nature 459, 583-U114.

Steinmann, T., Geldner, N., Grebe, M., Mangold, S., Jackson, C.L., Paris, S., Galweiler, L., Palme, K., and Jurgens, G. (1999). Coordinated polar localization of auxin efflux carrier PIN1 by GNOM ARF GEF. Science 286, 316-318.

Sun, T.P., and Kamiya, Y. (1994). The Arabidopsis GA1 locus encodes the Cyclase Ent-kauren Synthase-A of Gibberellin biosynthesis. Plant Cell 6, 1509-1518.

Sun, T.P., Goodman, H.M., and Ausubel, F.M. (1992). Cloning the Arabidopsis GA1 locus by genome subtraction. Plant Cell 4, 119-128.

Swarup, K., Benkova, E., Swarup, R., Casimiro, I., Peret, B., Yang, Y., Parry, G., Nielsen, E., De Smet, I., Vanneste, S., Levesque, M.P., Carrier, D., James, N., Calvo, V., Ljung, K., Kramer, E., Roberts, R., Graham, N., Marillonnet, S., Patel, K., Jones, J.D.G., Taylor, C.G., Schachtman, D.P., May, S., Sandberg, G., Benfey, P., Friml, J., Kerr, I., Beeckman, T., Laplaze, L., and Bennett, M.J. (2008). The auxin influx carrier LAX3 promotes lateral root emergence. Nature Cell Biology 10, 946-954.

Tanimoto, E. (2005). Regulation of root growth by plant hormones - Roles for auxin and gibberellin. Critical Reviews in Plant Sciences 24, 249-265.

Titapiwatanakun, B., Blakeslee, J.J., Bandyopadhyay, A., Yang, H., Mravec, J., Sauer, M., Cheng, Y., Adamec, J., Nagashima, A., Geisler, M., Sakai, T., Friml, J., Peer, W.A., and Murphy, A.S. (2009). ABCB19/PGP19 stabilises PIN1 in membrane microdomains in Arabidopsis. Plant J. 57, 27-44.

Tyler, L., Thomas, S.G., Hu, J.H., Dill, A., Alonso, J.M., Ecker, J.R., and Sun, T.P. (2004). DELLA proteins and gibberellin-regulated seed germination and floral development in Arabidopsis. Plant Physiol. 135, 1008-1019.

Ubeda-Tomas, S., Swarup, R., Coates, J., Swarup, K., Laplaze, L., Beemster, G.T.S., Hedden, P., Bhalerao, R., and Bennett, M.J. (2008). Root growth in Arabidopsis requires gibberellin/DELLA signalling in the endodermis. Nature Cell Biology 10, 625-628.

Ubeda-Tomas, S., Federici, F., Casimiro, I., Beemster, G.T.S., Bhalerao, R., Swarup, R., Doerner, P., Haseloff, J., and Bennett, M.J. (2009). Gibberellin Signaling in the Endodermis Controls Arabidopsis Root Meristem Size. Curr. Biol. 19, 1194-1199.

Ueguchi-Tanaka, M., Nakajima, M., Motoyuki, A., and Matsuoka, M. (2007). Gibberellin receptor and its role in gibberellin signaling in plants. Annual Review of Plant Biology 58, 183-198.

Ueguchi-Tanaka, M., Ashikari, M., Nakajima, M., Itoh, H., Katoh, E., Kobayashi, M., Chow, T.Y., Hsing, Y.I.C., Kitano, H., Yamaguchi, I., and Matsuoka, 
M. (2005). GIBBERELLIN INSENSITIVE DWARF1 encodes a soluble receptor for gibberellin. Nature 437, 693-698.

Ulmasov, T., Murfett, J., Hagen, G., and Guilfoyle, T.J. (1997). Aux/IAA proteins repress expression of reporter genes containing natural and highly active synthetic auxin response elements. Plant Cell 9, 1963-1971.

Utsuno, K., Shikanai, T., Yamada, Y., and Hashimoto, T. (1998). AGR, an Agravitropic locus of Arabidopsis thaliana, encodes a novel membrane-protein family member. Plant and Cell Physiology 39, 1111-1118.

Vandenbussche, F., Fierro, A.C., Wiedemann, G., Reski, R., and Van der Straeten, D. (2007). Evolutionary conservation of plant gibberellin signalling pathway components. Bmc Plant Biology 7.

Vida, T.A., and Emr, S.D. (1995). A New Vital Stain for Visualizing Vacuolar Membrane Dynamics and Endocytosis in Yeast. J. Cell Biol. 128, 779-792.

Viotti, C., Bubeck, J., Stierhof, Y.D., Krebs, M., Langhans, M., van den Berg, W., van Dongen, W., Richter, S., Geldner, N., Takano, J., Jurgens, G., de Vries, S.C., Robinson, D.G., and Schumacher, K. (2010). Endocytic and Secretory Traffic in Arabidopsis Merge in the Trans-Golgi Network/Early Endosome, an Independent and Highly Dynamic Organelle. Plant Cell 22, 1344-1357.

Weijers, D., and Jurgens, G. (2004). Funneling auxin action: specificity in signal transduction. Curr. Opin. Plant Biol. 7, 687-693.

Went, F.W. (1926). On Growth accelerating Substances in the Coleoptile of Avena sativa. Proceedings of the Koninklijke Nederlandse Akademie van Wetenschappen 30, 10-19.

Wilson, R.N., Heckman, J.W., and Somerville, C.R. (1992). Gibberellin is required from flowering in Arabidopsis thaliana under short days Plant Physiol. 100, 403-408.

Wisniewska, J., Xu, J., Seifertova, D., Brewer, P.B., Ruzicka, K., Blilou, I., Rouquie, D., Scheres, B., and Friml, J. (2006). Polar PIN localization directs auxin flow in plants. Science 312, 883-883.

Wolbang, C.M., Davies, N.W., Taylor, S.A., and Ross, J.J. (2007). Gravistimulation leads to asymmetry of both auxin and gibberellin levels in barley pulvini. Physiologia Plantarum 131, 140-148.

Woodward, A., and Bartel, B. (2005). Auxin: regulation, action, and interaction. Ann Bot. 95, 707-735.

Yabuta, T. (1935). Biochemistry of the "bakanae" fungus of rice. Agriculture and Horticulture 10, 17-22.

Yamaguchi, S. (2008). Gibberellin metabolism and its regulation. Annual Review of Plant Biology 59, 225-251.

Yang, H.B., and Murphy, A.S. (2009). Functional expression and characterization of Arabidopsis ABCB, AUX 1 and PIN auxin transporters in Schizosaccharomyces pombe. Plant J. 59, 179-191.

Yasumura, Y., Crumpton-Taylor, M., Fuentes, S., and Harberd, N.P. (2007). Stepby-step acquisition of the gibberellin-DELLA growth-regulatory mechanism during land-plant evolution. Curr. Biol. 17, 1225-1230.

Zadnikova, P., Petrasek, J., Marhavy, P., Raz, V., Vandenbussche, F., Ding, Z.J., Schwarzerova, K., Morita, M.T., Tasaka, M., Hejatko, J., Van Der Straeten, D., Friml, J., and Benkova, E. (2010). Role of PIN-mediated auxin efflux in apical hook development of Arabidopsis thaliana. Development 137, 607-617.

Zander, M., La Camera, S., Lamotte, O., Metraux, J.P., and Gatz, C. (2010). Arabidopsis thaliana class-II TGA transcription factors are essential activators of jasmonic acid/ethylene-induced defense responses. Plant J. 61, 200-210. 


\section{Anhang}

\subsection{Abkürzungsverzeichnis}

\begin{tabular}{|c|c|}
\hline $\mathrm{ARF}$ & ADP-ribosylation factors \\
\hline At & Arabidopsis thaliana \\
\hline AUX1 & AUX1/LAX-Protein \\
\hline BFA & Brefeldin A \\
\hline BSA & Rinderserumalbumin \\
\hline d & Einheit für Tag \\
\hline DEX & Dexamethason \\
\hline DMSO & Dimethylsulfoxid \\
\hline DNA & Desoxyribonukleinsäure \\
\hline GA & Gibberellinsäure \\
\hline GAI & GA-Insensitive \\
\hline gai $\triangle 17$ & Dominant negative Form von GAI; deletierte DELLA-Domäne \\
\hline GEF & guanin nucleotide exchange factors \\
\hline GFP & Grün fluoreszierendes Protein \\
\hline GID1 & GA-insensitive dwarf \\
\hline \multirow[t]{2}{*}{ FM4-64 } & $\mathrm{N}$-(3-triethylammoniumpropyl)-4-(6-(4-(diethylamino) phenyl) \\
\hline & hexatrienyl) pyridinium dibromid \\
\hline $\mathrm{h}$ & Einheit für Stunde \\
\hline${ }^{3} \mathrm{H}$ IAA & Indol-3-essigsäure, $3-\left[5(\mathrm{n})-{ }^{3} \mathrm{H}\right] \mathrm{IAA}$, tritiiert \\
\hline IAA & Indol-3-essigsäure \\
\hline $\mathrm{KOH}$ & Kaliumhydroxid \\
\hline M & mol pro Liter \\
\hline MES & 2-(N-Morpholino)ethansulfonsäure \\
\hline MS & Murashige und Skoog Medium \\
\hline MVB & multi vesicular bodies \\
\hline NAA & 1-Naphthylessigsäure \\
\hline NPA & N-1-Naphthylphthalamid Säure \\
\hline PAC & Paclobutrazol \\
\hline pentuple & Linie mit Mutation in allen fünf DELLA-Proteinen \\
\hline
\end{tabular}




$\begin{array}{ll}\text { PCR } & \text { Polymerasekettenreaktion } \\ \text { pH } & \text { negativ dekadischer Logarithmus der Protonenkonzentration } \\ \text { PID } & \text { PINOID } \\ \text { PIN } & \text { PIN-Formed } \\ \text { PGP } & \text { P-Glykoprotein } \\ \text { PM } & \text { Plasmamembran } \\ \text { Pp } & \text { Physcomitrella patens } \\ \text { PP2A } & \text { Phosphatase 2A } \\ \text { PVC } & \text { pre-vakuoläres Kompartiment } \\ \text { ox } & \text { Oxidase } \\ \text { RGA } & \text { Repressor von gal-3 } \\ \text { RGL1 } & \text { RGA-LIKE1 } \\ \text { RGL2 } & \text { RGA-LIKE2 } \\ \text { RGL3 } & \text { RGA-LIKE3 } \\ \text { RNA } & \text { Ribonukleinsäure } \\ \text { RT-PCR } & \text { Realtime Polymerasekettenreaktion } \\ \text { s } & \text { Einheit für Sekunde } \\ \text { SNX } & \text { sorting nexin } \\ \text { TGN } & \text { trans-Golgi-Netzwerk } \\ \text { Uni } & \text { Uniconazol } \\ \text { VPS } & \text { Wortmannin } \\ \text { WM } & \end{array}$




\subsection{Verwendete synthetische Oligonukleotide}

\begin{tabular}{|c|c|c|c|}
\hline Nr: & Name & Sequenz & Verwendung \\
\hline 1 & RGA205 & TCGCTTAGTAGTTAGTACTC & Genotypisierung \\
\hline 2 & RGA253 & CATAGACCATAGTATTCGTGA & Genotypisierung \\
\hline 3 & RGA212 & GGTGATTTTCACGGTGGTTG & Genotypisierung \\
\hline 6 & gai-t6 300 & CTAGATCCGACATTGAAGGA & Genotypisierung \\
\hline 7 & gai-t6 304 & TCGGTACGGGATTTTCGCAT & Genotypisierung \\
\hline 8 & GAI 302 & AGCATCAAGATCAGCTAAAG & Genotypisierung \\
\hline 37 & RT_UBQ5_fwd & GACGCTTCATCTCGTCC & RT-PCR \\
\hline 38 & RT_UBQ5_rev & GTAAACGTAGGTGAGTCCA & RT-PCR \\
\hline 44 & GAI_Stab_fwd & GTAACGGCATGGATGTTGC & Genotypisierung \\
\hline 45 & GAI_Stab_rev & TGGTCTAAGCTCAAGCATCG & Genotypisierung \\
\hline 51 & GFP_fwd & CTGTTCCATGGCCAACACTT & Genotypisierung \\
\hline 52 & GFP_rev & TTTGGAAAGGGCAGATTGTG & Genotypisierung \\
\hline 79 & RT_GA20ox1_fwd & CCGTAACTGTAGAAGACT & RT-PCR \\
\hline 80 & RT_GA20ox1_rev & ATACTCTTGATACACCTTCCT & RT-PCR \\
\hline 95 & $\mathrm{LB} \bar{b} 1.3$ & ATTTTGCCGATTTCGGAAC & Genotypisierung \\
\hline 92 & Pin1_In-Ex_fwd & AGAAGACGGTGGTCCTGCTA & Genotypisierung \\
\hline 93 & Pin1_In-Ex_rev & GCAGGTCCAACGACAAATCT & Genotypisierung \\
\hline 138 & vps29-3 LP & GCGGCTGATCTACCTCCTAAG & Genotypisierung \\
\hline 139 & vps29-3 RP & CAAAATAACAAGCGAGCCAAC & Genotypisierung \\
\hline 173 & RT_GH3.1_fwd & AACTTATGCCGACCATTAAAGAA & RT-PCR \\
\hline 174 & RT_GH3.1_rev & TCTAGACCCGGCACATACAA & RT-PCR \\
\hline 179 & snxi-1_LP & TCAAATTAGGCAATGGCGTAC & Genotypisierung \\
\hline 180 & snx1-1_RP & TATGCAAATTGCAGTCCTTCC & Genotypisierung \\
\hline 201 & GABI-kat T-DNA & CCCATTTGGACGTGAATGTAGACAC & Genotypisierung \\
\hline Qiagen & RT_PIN2 & QT00843850 & RT-PCR \\
\hline Qiagen & RT_PIN7 & QT00864122 & RT-PCR \\
\hline Qiagen & RT_RGA & QT00713720 & RT-PCR \\
\hline Qiagen & RT_GAI & QT00858354 & RT-PCR \\
\hline Qiagen & RT_RGL1 & QT00887670 & RT-PCR \\
\hline Qiagen & RT_RGL2 & QT00887670 & RT-PCR \\
\hline Qiagen & RT_RGL3 & QT00831474 & RT-PCR \\
\hline
\end{tabular}




\subsection{Verwendete Arabidopsis thaliana Linien}

\begin{tabular}{|c|c|c|c|}
\hline Name & Ökotyp & Transgen & Spender \\
\hline $\begin{array}{l}\text { Landsberg } \\
\text { erecta }\end{array}$ & Ler & & $\begin{array}{l}\text { Prof. Dr. Jiri Friml, VIB } \\
\text { Plant Systems Biology, } \\
\text { Gent, Belgien }\end{array}$ \\
\hline DR5::GFP & Col-0 & $\begin{array}{l}\text { Auxin-responsiver Promotor mit } \\
\text { GFP fusioniert (Friml et al., 2003) }\end{array}$ & $\begin{array}{l}\text { Prof. Dr. Jiri Friml, VIB } \\
\text { Plant Systems Biology, } \\
\text { Gent, Belgien }\end{array}$ \\
\hline rga/gai & Ler & $\begin{array}{l}\text { Kreuzung zweier DELLA T-DNA } \\
\text { Insertionslinien: rga24 und gai-t6 } \\
\text { (Dill and Sun, 2001) }\end{array}$ & $\begin{array}{l}\text { Prof. Dr. Jiri Friml, VIB } \\
\text { Plant Systems Biology, } \\
\text { Gent, Belgien }\end{array}$ \\
\hline $\begin{array}{l}\text { TA::PIN2- } \\
\text { GFP }\end{array}$ & Col-0 & $\begin{array}{l}\text { Dexamethason indizierbares PIN2- } \\
\text { GFP (Abas et al., 2006) }\end{array}$ & $\begin{array}{l}\text { Dr. Christian Luschnig, } \\
\text { Universität für } \\
\text { Bodenkunde, Wien, } \\
\text { Österreich }\end{array}$ \\
\hline pentuple & $\begin{array}{l}\text { Col-0 } \\
+ \text { Ler }\end{array}$ & $\begin{array}{l}\text { Kreuzung der fünf DELLA T-DNA } \\
\text { Insertionslinien: gai- } t 6, r g a-t 2, r g l 1- \\
1, r g l 2-1, r g l 3-1 \text { NASC ID: } 16298 \\
\text { (Feng et al., 2008) }\end{array}$ & $\begin{array}{l}\text { Nottingham Arabidopsis } \\
\text { Stock Centre, University } \\
\text { of Nottingham, United } \\
\text { Kingdom }\end{array}$ \\
\hline gal-3 & Ler & $\begin{array}{l}\text { Neutronen Mutagenese des GA1- } \\
\text { Locus NASC ID: } 3104 \text { (Sun et al., } \\
\text { 1992) }\end{array}$ & $\begin{array}{l}\text { Nottingham Arabidopsis } \\
\text { Stock Centre, University } \\
\text { of Nottingham, United } \\
\text { Kingdom }\end{array}$ \\
\hline rgll-2-3 & Ler & $\begin{array}{l}\text { Kreuzung dreier DELLA T-DNA } \\
\text { Insertionslinien: rgll-1, rgl2-1, } \\
\text { rgl3-1 (Tyler et al., 2004) }\end{array}$ & $\begin{array}{l}\text { Prof. Dr. Tai-ping Sun, } \\
\text { Duke University, Durham, } \\
\text { NC, USA }\end{array}$ \\
\hline
\end{tabular}




\subsection{Hormone und Inhibitoren}

\begin{tabular}{llllc} 
Name & Stammlösung & Endkonzentration & Lösungsmittel & Lagerung \\
\hline ACC & $500 \mathrm{mM}$ & $50 \mu \mathrm{M} \mathrm{FE}$ & $\mathrm{H}_{2} \mathrm{O}$ & frisch \\
AgNO $_{3}$ & $20 \mathrm{mM}$ & $20 \mu \mathrm{M} \mathrm{FE}$ & $\mathrm{H}_{2} \mathrm{O}$ & $-20^{\circ} \mathrm{C}$ \\
BFA & $100 \mathrm{mM}$ & $50 \mu \mathrm{M} \mathrm{SP}$ & DMSO & $-20^{\circ} \mathrm{C}$ \\
CHX & $100 \mathrm{mM}$ & $50 \mu \mathrm{M} \mathrm{FL}$ & DMSO & $-20^{\circ} \mathrm{C}$ \\
DEX & $10 \mathrm{mM}$ & $10 \mu \mathrm{M} \mathrm{FE}$ & DMSO & $-20^{\circ} \mathrm{C}$ \\
FM4-64 & $2 \mathrm{mM}$ & $2 \mu \mathrm{M} \mathrm{FL}$ & DMSO & RT/dunkel \\
GA 3 & $50 \mathrm{mM}$ & $50 \mu \mathrm{M} \mathrm{SP} / 10 \mu \mathrm{M} \mathrm{FE}$ & DMSO & $-20^{\circ} \mathrm{C}$ \\
IAA & $100 \mathrm{mM}$ & $10 \mu \mathrm{M} \mathrm{SP}$ & DMSO & frisch \\
MG132 & $50 \mathrm{mM}$ & $50 \mu \mathrm{M} \mathrm{FL}$ & DMSO & $-20^{\circ} \mathrm{C}$ \\
NAA & $10 \mathrm{mM}$ & $0,1 \mu \mathrm{M} \mathrm{FE}$ & DMSO & $-20^{\circ} \mathrm{C}$ \\
NPA & $100 \mathrm{mM}$ & $10 \mu \mathrm{M} \mathrm{FE}$ & DMSO & frisch \\
PAC & $10 \mathrm{mM}$ & $10 \mu \mathrm{M} \mathrm{SP}$ & DMSO & $-20^{\circ} \mathrm{C}$ \\
PAO & $30 \mathrm{mM}$ & $30 \mu \mathrm{M} \mathrm{SP}$ & DMSO & $-20^{\circ} \mathrm{C}$ \\
Tamoxifen & $10 \mathrm{mM}$ & $2 \mu \mathrm{M} \mathrm{FE}$ & DMSO & $-20^{\circ} \mathrm{C}$ \\
Tyr23A & $30 \mathrm{mM}$ & $30 \mu \mathrm{M} \mathrm{FE}$ & DMSO & $-20^{\circ} \mathrm{C}$ \\
Uni & $100 \mathrm{mM}$ & $10 \mu \mathrm{M} \mathrm{SP}$ & DMSO & $-20^{\circ} \mathrm{C}$ \\
WM & $10 \mathrm{mM}$ & $10 \mu \mathrm{M} \mathrm{SP}$ & DMSO & $-20^{\circ} \mathrm{C}$
\end{tabular}

Abkürzungen: FE fest; FL flüssig; SP sprühen. Die Abkürzungen beziehen sich auf die Art des Medium während der Behandlung. FE, Substanz wird über festes 1/2 MSMedium appliziert, auf dem die Keimlinge wachsen. FL, Substanz wird über flüssiges 1/2 MS-Medium appliziert, so dass die Keimlinge schwimmend in diesem inkubieren können. SP, Keimlinge werden direkt auf dem festen 1/2 MS-Medium, auf dem sie gewachsen sind, besprüht und auf der Platte inkubiert. 


\section{Danksagung}

An dieser Stelle möchte ich mich bei all denjenigen bedanken, die mich bei der Anfertigung dieser Dissertation unterstützt haben und mir zur Seite standen.

Allen voran bei meinen drei Doktorvätern Prof. Dr. Jiri Friml, Prof. Dr. Ingo Heilmann und PD Dr. Thomas Teichmann, die mir immer mit Rat und Tat bei diesem spannendem Projekt zur Seite standen und mir dennoch die Freiheit gaben, mich wissenschaftlich entfalten zu können. Durch die engagierte Art aller Drei schritt das Projekt trotz einiger Startschwierigkeiten produktiv und zügig voran.

Herrn Prof. Dr. Volker Lipka für die Möglichkeit, meine Arbeit in seiner Abteilung anfertigen zu dürfen, für eine Vielzahl von Anregungen, sowie eine stetige Bereitschaft, den vorhandenen Diskussionsbedarf zu decken.

Bei Prof. Dr. Jan Schirawski sowie Prof. Dr. Andrea Polle und Prof. Dr. Stephan Jakobs bedanke ich mich für die Bereitschaft, zusammen mit meinen Thesis Komitee meine Prüfungskommission zu bilden.

Besonders möchte ich mich noch mal bei Thomas Teichmann, Ingo Heilmann und Anja Auspurg bedanken für das hingebungsvolle Korrekturlesen meiner Arbeit

Den technischen Assistentinnen Gaby Schauermann, Sabine Wolfarth und Melanie Klenke, dass der Laboralltag immer wie ein geöltes Uhrwerk lief.

Bei unseren Gärtnern Uwe Wedemeyer und Felicitas Glasenapp für den Service rund um unsere geliebten Arabidopsis Pflanzen. Herr Wedemeyer stand mir auch immer mit Rat und Tat zur Seite bei Problemen mit meiner heimischen Pflanzenwelt.

Prof. Dr. Christiane Gatz und der ganzen Abteilung „Molekularbiologie und Physiologie der Pflanze“ möchte ich für die Bereitstellung des Realtime-PCR Equipments und für technischen Support danken. 
Marta Zwiewka für ihre unersetzliche Hilfe bei PIN1 Immunolokalisationen in Arabidopsis und PIN2 Immunoblots.

Dem ganzen LARI-Team, vor allem Thomas Klein und Gabriele Lehmann für ihre immer hilfsbereite Art rund um die Isotopen.

Prof. Dr. Stephan Jakobs und Dr. Daniel Neumann für die Bereitstellung von 35S::GFP Samen, den Atto konjugierten Antikörpern und immer einen spontanen Platz am SP5.

Prof. Dr. Eva Zazimalova und Petr Klima danke ich für Auxintransport Messungen in BY2 Zellen.

Jakub Rolcik für die Auxinquantifizierung in diversen GA-Mutanten.

Vielen einzelnen auf der ganzen Welt für das Bereitstellen von Saatgut. NASC, Taiping Sun, Jiri Friml, Jürgen Kleine-Vehn, Stephan Jakobs, Thierry Gaude.

Der ganzen Arbeitsgruppe Lipka mit Michael Reusche, Rene Fuchs, Elena Petutschnig, Anja Auspurg, Magdalena Plath, Charlotte Roth, Marnie Schwarz, Marcel Wiermer und ehemaligen Christine Klapprodt und Juliane Horlacher für die ständige Hilfsbereitschaft bei den Tücken des Alltags, die angenehme Arbeitsatmosphäre und die vielen kleinen Feiern.

Dem ganzen Friml Labor für den natürlich immer schönen Aufenthalt in Belgien inklusive kulinarischer Betreuung, zahlreiche anregungsvolle Diskussionen und viele, viele und nochmals viele Pflanzenlinien.

Meiner ehemaligen Arbeitgruppe mit Ingo Heilmann, Irene Stenzel, Till Ischebeck, Alina Mosblech, Jennifer Lerche, Mareike Heilmann und Stephanie Werner die mir vor allem anfangs bei technischen Problemen zu Seite standen und auch jetzt noch wie meine zweite „Science Family“ sind.

Meiner Bachelor Studentin Alexandra Matei, die voller Begeisterung an diesem Auxinprojekt mitwirkte. 
11. Curriculum Vitae

Christian Löfke

EDUCATION

EXTRACURRICULAR ACTIVITIES 
RESEARCH EXPERIENCE

SKILLS \& INTERESTS

PUBLICATIONS 


\section{CONFERENCES AND PRESENTATIONS}


REFEREES 